\title{
De ontwikkeling van de kosten van beroepsziekten en arbeidsongevallen in Nederland : een economische inschatting van de schadelast voor verzekeraars
}

Citation for published version (APA):

van Mierlo, J. G. A. (1995). De ontwikkeling van de kosten van beroepsziekten en arbeidsongevallen in Nederland : een economische inschatting van de schadelast voor verzekeraars. METEOR, Maastricht University School of Business and Economics. METEOR Research Memorandum No. 022 https://doi.org/10.26481/umamet.1995022

Document status and date:

Published: 01/01/1995

DOI:

10.26481/umamet.1995022

Document Version:

Publisher's PDF, also known as Version of record

Please check the document version of this publication:

- A submitted manuscript is the version of the article upon submission and before peer-review. There can be important differences between the submitted version and the official published version of record.

People interested in the research are advised to contact the author for the final version of the publication, or visit the DOI to the publisher's website.

- The final author version and the galley proof are versions of the publication after peer review.

- The final published version features the final layout of the paper including the volume, issue and page numbers.

Link to publication

\footnotetext{
General rights rights.

- You may freely distribute the URL identifying the publication in the public portal. please follow below link for the End User Agreement:

www.umlib.nl/taverne-license

Take down policy

If you believe that this document breaches copyright please contact us at:

repository@maastrichtuniversity.nl

providing details and we will investigate your claim.
}

Copyright and moral rights for the publications made accessible in the public portal are retained by the authors and/or other copyright owners and it is a condition of accessing publications that users recognise and abide by the legal requirements associated with these

- Users may download and print one copy of any publication from the public portal for the purpose of private study or research.

- You may not further distribute the material or use it for any profit-making activity or commercial gain

If the publication is distributed under the terms of Article 25fa of the Dutch Copyright Act, indicated by the "Taverne" license above, 


\title{
DE ONTWIKKELING VAN DE KOSTEN VAN BEROEPSZIEKTEN EN ARBEIDSONGEVALLEN IN NEDERLAND \\ Een economische inschatting van de schadelast voor verzekeraars
}

\author{
Concept-tekst van Hoofdstuk 6 in \\ Verzekering en de Groeiende Aansprakelijkheidslast \\ Redactie: M.G. Faure en T. Hartlief \\ METRO/Verbond van Verzekeraars \\ Uitgeverij Kluwer, Deventer 1995
}

\author{
Dr J.G.A. van Mierlo \\ Universitair Hoofddocent Openbare Financiën/ \\ Economie van de Publieke Sector \\ Vakgroep Algemene Economie \\ Faculteit der Economische Wetenschappen \\ Rijksuniversiteit Limburg \\ Postbus 616 \\ 6200 MD Maastricht
}

Tweede Versie

September 1995 


\section{Samenvatting}

De Ontwikkeling van de Kosten van Beroepsziekten en Arbeidsongevallen in Nederland. Een economische inschatting van de schadelast voor verzekeraars

\section{J.G.A. van Mierlo}

In dit rapport wordt een economische inschatting gepresenteerd van de ontwikkeling van de kosten van beroepsziekten en arbeidsongevallen in Nederland, voor zo ver deze tot uiting komen in de schadelast van verzekeraars uit hoofde van aansprakelijkheidsverzekeringen van werkgevers. Kostenontwikkelingen worden bepaald door een volumecomponent (het aantal toegekende claims) en een prijscomponent (de gemiddelde hoogte van de toegekende claims). De ontwikkeling van de kosten in het verleden wordt met behulp van een trendanalyse in kaart gebracht. Vervolgens worden aan de hand van drie mogelijke toekomstscenario's de kostenontwikkelingen in de toekomst, tot aan het jaar 2005, geëxtrapoleerd. Op deze manier kan de toekomstige ontwikkeling van de schadelast voor verzekeraars uit hoofde van de aansprakelijkheidsverzekering van werkgevers, in kwantitatieve termen worden benaderd.

\section{Summary}

Cost Developments caused by Industrial Diseases and Accidents in the Netherlands. An economic analysis of the financial consequences for insurance companies

\section{J.G.A. van Mierlo}

In this research memorandum, an economic analysis is presented of the cost developments caused by industrial diseases and accidents in the Netherlands. The analysis is limited to these costs as far as they imply a financial burden for insurance companies, caused by payments on acknowledged claims on liability insurances of employers.

Cost developments are determined by a volume component (the number of acknowledged claims) and a price component (the average payment level of the acknowledged claims). Cost developments in the past are calculated on basis of a trend analysis. Three different scenarios for the future are distinguished, which are the basis for calculation of three different extrapolations of cost developments in the future, towards the year 2005. On this way, future developments in the financial burden of insurance companies, resulting from liability insurances of employers, can be traced in quantitative terms. 


\section{Inhoud}

Samenvatting

1 Inleiding

1.1 Achtergronden van het onderzoeksproject

1.2 Probleemstelling en aanpak van dit deelonderzoek

2 Een causaal model

3 Trendanalyse voor de periode 1990-1993

3.1 Inleiding

3.2 Volume-ontwikkeling van beroepsziekten

3.3 Volume-ontwikkeling van arbeidsongevallen

3.4 Prijs-ontwikkeling van beroepsziekten

3.5 Totale kosten-ontwikkeling van beroepsziekten

4 Toekomstscenario's voor de periode tot 2005

4.1 Drie toekomstscenario's

4.2 Het minimumscenario

4.3 Twee middenscenario's

4.4 Het maximumscenario

5 Conclusies en kanttekeningen

Bijlage Onderzoek Werkgeversaansprakelijkheid 


\section{Inleiding}

\subsection{Achtergronden van het onderzoeksproject}

Onder leiding van het Maastrichtse onderzoeksinstituut METRO is een onderzoek uitgevoerd in opdracht van de afdeling Algemene Aansprakelijkheid van de Sector Schadeverzekering van het verbond van Verzekeraars. Toegespitst op de aansprakelijkheid van de werkgever voor bedrijfsongevallen en beroepsziekten is onderzocht, of en in hoeverre verzekeraars zich in de toekomst geconfronteerd zullen zien met een groeiende aansprakelijkheidslast. In dat kader is gebruik gemaakt van juridische, gezondheidskundige, alsmede economische analyses. Het gehele onderzoeksverslag wordt gepubliceerd als boek onder redactie van M.G. Faure en T. Hartlief, Verzekering en de Groeiende Aansprakelijkheidslast (Een juridisch, gezondheidskundig en economisch onderzoek naar ontwikkelingen met betrekking tot de aansprakelijkheidslast en de consequentie voor verzekeraars naar aanleiding van de werkgeversaansprakelijkheid voor bedrijfsongevallen en beroepsziekten), Uitgeverij Kluwer en Nederlands Verbond van Verzekeraars, Deventer 1995.

Dit research memorandum bevat de concept-tekst van hoofdstuk 6 van dit boek. In dit hoofdstuk wordt het economisch gedeelte van het onderzoek gerapporteerd. Aan de hand van een aantal scenario's, die zijn vastgesteld en ingevuld op basis van de juridische en gezondheidskundige deelonderzoeken, wordt bepaald met welke schadelast de verzekeraars in de toekomst geconfronteerd zullen worden.

\subsection{Probleemstelling en aanpak van dit deelonderzoek}

Beroepsziekten en arbeidsongevallen zijn geen statisch verschijnsel, maar ontwikkelen zich in de tijd. Dat geldt in het algemeen, dat geldt ook voor Nederland. Allerlei technologische en maatschappelijke factoren (economisch, gezondheidskundig, juridisch en politiek/beleidsmatig) beïnvloeden de getalsmatige ontwikkelingen van beroepsziekten en arbeidsongevallen. Die getalsmatige ontwikkelingen moeten worden onderscheiden in twee componenten: de volume-component $\mathrm{Q}$ en de prijscomponent P. De volumecomponent $Q$ verwijst naar de totale omvang van de beroepsziekten en arbeidsongevallen, zowel absoluut als relatief (bijvoorbeeld per 100.000 werknemers). De prijscomponent $\mathrm{P}$ verwijst naar de kosten per beroepsziekte of arbeidsongeval, waarbij verschillende kostensoorten moeten worden onderscheiden. De totale maatschappelijke kosten van beroepsziekten en arbeidsongevallen zijn het produkt van de volume-ontwikkeling en van de prijsontwikkeling: $Q * P$. Wanneer de werkgevers honderd procent aansprakelijk zijn voor het optreden van beroepsziekten en arbeidsongevallen, wanneer zij eveneens honderd procent aansprakelijk zijn voor de kosten die daarmee gaan gepaard en wanneer de verzekeraars beide aansprakelijkheden volledig, voor honderd procent, dekken, zijn de totale maatschappelijke kosten gelijk aan de totale kosten van schade-uitkering door de verzekeraars.

In dit hoofdstuk wordt een economische analyse gepresenteerd van de ontwikkeling van de totale kosten van verzekeraars als gevolg van schade-uitkeringen uit hoofde van werkgeversaansprakelijkheid voor beroepsziekten en arbeidsongevallen. Daarbij wordt gekeken naar trendmatige ontwikkelingen in het verleden, worden deze trendmatige ontwikkelingen doorgetrokken naar de toekomst (waarbij een projectietermijn van tien jaar vooruit wordt gehanteerd) en worden drie toekomstscenario's doorgerekend die wat betreft mogelijke trendbreuken van elkaar verschillen. Deze scenario's zijn het minimumscenario (de trend zet zich ongewijzigd door), twee middenscenario's (A en B, waarin telkens één enkele trendbreuk wordt voorzien) en een maximumscenario (waarin beide trendbreuken gelijktijdig optreden).

In paragraaf twee van dit hoofdstuk wordt een causaal model gepresenteerd, waarin de ontwikkeling van de totale kosten van schade-uitkeringen door verzekeraars uit hoofde van werkgeversaansprakelijkheid voor beroepsziekten en arbeidsongevallen als afhankelijke variabele is opgenomen. In dat model worden vervolgens ook de onafhankelijke en interveniërende variabelen opgenomen, alsmede de invloeden daarvan op de afhankelijke variabele. Op deze manier worden de determinanten van de totale kosten-ontwikkeling in kaart gebracht. Dit causale model is een theoretisch model, dat empirisch ingevuld zou moeten worden. Eerder hebben wij in dit verslag echter gezien, dat te veel empirische gegevens ontbreken om dit causale model empirisch in te vullen en te toetsen. Daarom volstaan wij in de derde paragraaf met een trendanalyse, waarin de kostenontwikkeling (de afhankelijke variabele) niet wordt afgeleid uit ontwikkelingen van de determinanten van deze kostenontwikkeling (zoals gespecificeerd in het causale model), maar wordt gerelateerd aan de tijd. 
Daarbij gaat het om een structuuranalyse. Conjuncturele schommelingen rond de trendmatige ontwikkeling worden buiten beschouwing gelaten. In paragraaf 4 worden toekomstige kostenontwikkelingen geschetst aan de hand van de trendanalyse in paragraaf 3 enerzijds en een drietal mogelijke toekomstscenario's anderzijds. Tenslotte worden in de vijfde paragraaf enkele conclusies getrokken.

\section{Een causaal model}

In een causaal model worden de causale verbanden weergegeven tussen afhankelijke, onafhankelijke en interveniërende variabelen. De variabelen en de causale verbanden tussen de variabelen kunnen worden afgeleid uit de (economische of sociaalwetenschappelijke) theorie waarin oorzaken en gevolgen van bepaalde maatschappelijke verschijnselen aan elkaar worden gerelateerd. Dit theoretische causale model zou vervolgens empirisch moeten worden getoetst aan de hand van voorhanden empirische gegevens. Aan de hand van de toetsing kunnen bijvoorbeeld de richting, het teken en de sterkte van de onderlinge verbanden in het model worden bepaald. Wij volstaan met de presentatie van een theoretisch causaal model, omdat de empirische gegevens niet voorhanden zijn om dit causale model ook te toetsen.

In dit theoretische causale model onderscheiden wij de volgende variabelen.

I. Afhankelijke variabelen:

1. totale schadelast voor de verzekeraars uit hoofde van verzekerde werkgeversaansprakelijkheid voor beroepsziekten en arbeidsongevallen (PQ), samengesteld uit:

2. prijscomponent $P$ : de gemiddelde hoogte van de toegekende claims;

3. volumecomponent Q: het aantal toegekende claims.

II. Onafhankelijke variabelen:

4. omvang van de verzekerde, werkzame beroepsbevolking;

5. economisch ontwikkelingsniveau en bedrijfstakstructuur;

6. duur en ernst van beroepsziekten en letsels als gevolg van arbeidsongevallen;

7. aard en frequentie van beroepsziekten en letsels als gevolg van arbeidsongevallen;

8. opkomst van nieuwe beroepsziekten en arbeidsongevallen.

III. Interveniërende variabelen:

9. diverse schadecomponenten, onder te verdelen in kosten van:

a. gezondheidszorg (cure, behandeling en care, verzorging);

b. inkomensderving;

c. juridische bijstand;

d. smartegeld;

e. 'punitive damages';

10. claimgedrag, onder te verdelen in:

f. procescultuur: 'procedurelust' aan de vraagzijde;

g. processtructuur: procesmonopolie aan de aanbodzijde;

h. beloningsstructuur van de advocatuur 1: 'contingency fees';

i. beloningsstructuur van de advocatuur 2: 'no cure, no pay';

11. veranderingen in de wetgeving met betrekking tot:

j. aansprakelijkheid;

k. sociale zekerheid;

12. jurisprudentie: de rechtsontwikkeling als gevolg van rechterlijke uitspraken.

Deze twaalf onderscheiden variabelen worden onder gebracht in het theoretische causale model dat wij in figuur 1 hieronder presenteren. Dit theoretische causale model behoeft verder geen toelichting. Wel zij opgemerkt dat met name op de variabelen 9, 10 en 11 invloed wordt uitgeoefend door bijvoorbeeld actie- en belangengroepen. Deze invloed is buiten het model gelaten. Dit model is mede afgeleid van het zogeheten 'filtermodel', zoals dat door Gorissen en Schröer in hoofdstuk 4 van het eindrapport is gepresenteerd. 
(Figuur 1) 
Figuur 1. Theoretisch causaal model

5. Economisch ontwikkelingsniveau en bedrijfstakstructuur
4. Omvang van de verzekerde, werkzame beroepsbevolking
6. Duur en ernst van beroepsziekten en letsels als gevolg van arbeidsongevallen
7. Aard en frequentie van beroepsziekten

en letsels als gevolg van arbeidsongevallen
8. Opkomst van nieuwe beroepsziekten en

arbeidsongevallen
9. Schadecomponenten, kosten van:

a. gezondheidszorg (cure/care)

b. inkomensderving

c. juridische bijstand

d. smartegeld

e. 'punitive damages'
10. Claimgedrag, bepaald door:

f. procescultuur

g. procesmonopolie

h. 'contingency fees'

i. 'no cure, no pay'

11. Veranderingen in wetgeving: j. aansprakelijkheid

k. sociale zekerheid

12. Jurisprudentie

3. $\mathrm{Q}=$ aantal toegekende claims (vraagzijde)
2. $\mathrm{P}=$ gemiddelde hoogte van toegekende claims (vraagzijde)

1. $\mathrm{P} * \mathrm{Q}=$ totale schadelast

voor verzekeraars uit hoofde

van werkgeversaansprakelijkheid 


\section{Trendanalyse voor de periode 1990-1993}

\subsection{Inleiding}

Gegevens over de trendmatige ontwikkelingen van beroepsziekten en arbeidsongevallen zijn in Nederland nauwelijks voorhanden. Daarom zijn in het gezondheidskundige deelonderzoek de ontwikkelingen van beroepsziekten en arbeidsongevallen in Duitsland tot uitgangspunt genomen en getransponeerd naar de Nederlandse situatie. De veronderstellingen waaronder dit is gedaan en de wijze waarop deze transponatie is uitgevoerd, zijn uitvoerig beschreven in hoofdstuk 4 van het eindrapport (Faure en Hartlief, 1995).

In deze paragraaf worden enkele trendanalyse gepresenteerd op basis van deze op Nederland overgeplante gegevens. Daarbij wordt de periode 1990-1993 gehanteerd, met daarin vier meetpunten: 1990, 1991, 1992 en 1993. Verder is een onderscheid gemaakt in achttien bedrijfstakken. Deze worden gepresenteerd in het eerste deel van de bijlage bij dit hoofdstuk. Tenslotte wordt in het tweede deel van deze bijlage de ontwikkeling in de gemiddelde kosten van beroepsziekten weergegeven. Deze ontwikkeling is berekend op basis van de kostenberekening voor 1 juni 1995, die is uitgevoerd door mw. H.W.J. van Dongen, maar waarvan nog geen publikatie is voorzien. De cijfers van voorgaande jaren zijn berekend op basis van de prijsinflatiecijfers in procenten, zoals gepubliceerd door het CBS. Op deze wijze wordt een gemiddelde kostenontwikkeling voor beroepsziekten verkregen over de periode 1990-1995.

(Bijlage 1)

\subsection{Volume-ontwikkeling van beroepsziekten}

Eerst worden de ontwikkelingen in de beroepsziekten beschouwd. De achttien onderscheiden bedrijfstakken worden ingedeeld in drie groepen: groep 1 omvat de vijf bedrijfstakken met de hoogste aantallen beroepsziekten, groep 3 de vijf bedrijfstakken met de laagste aantallen beroepsziekten, en groep 2 de acht overblijvende bedrijfstakken met aantallen beroepsziekten die daar tussenin liggen. Groep 1 bevat dus de meest riskante bedrijfstakken, groep 2 de normaal-riskante bedrijfstakken en groep 3 de minst riskante bedrijfstakken. In tabel 1 worden de beroepsziekten naar absolute aantallen per risicogroep gepresenteerd (berekend als gemiddelde over vier jaren van 1990 tot en met 1994), in tabel 2 wordt datzelfde gedaan in relatieve aantallen, omgerekend naar aantallen per 100.000 werknemers werkzaam in de betrokken bedrijfstakken.

(Tabellen 1 en 2)

De incidentie van beroepsziekten moet natuurlijk worden bezien naar omvang van de bedrijfstak, gemeten in aantallen werknemers die in die bedrijfstak werken. Daarom geeft tabel 2 een beter inzicht dan tabel 1. Bezien wij eerst tabel 1, waarin de absolute cijfers, onafhankelijk van het aantal werknemers dat in de bedrijfstak werkt, worden gepresenteerd.

Tot de meest riskante groep horen dan de volgende bedrijfstakken:

18. gezondheidsdiensten en maatschappelijke dienstverlening;

13. bouwnijverheid en -installatiebedrijven;

4. metaalprodukten-, machine-, transportmiddelenindustrie en autoreparatiebedrijven;

12. voedings- en genotsmiddelenindustrie en horeca;

6. aardolie-, chemische en rubberindustrie.

Tot de minst riskante groep horen de volgende bedrijfstakken:

8. papier- en papierwarenindustrie;

11. textiel- en kledingindustrie; 
2. openbare nutsbedrijven;

9. grafische industrie, binderijen en uitgeverijen;

10. leder-, schoen- e.a. lederwarenindustrie.

De overige acht bedrijfstakken bevinden zich in de middengroep van gemiddelde risico's.

In tabel 2 worden de relatieve aantallen weergegeven, afhankelijk van het aantal werknemers dat in de respectievelijke bedrijfstakken werkt. Dat levert het volgende beeld op.

Tot de meest riskante groep horen dan de volgende bedrijfstakken:

3. basis metaalindustrie;

6. aardolie-, chemische en rubberindustrie;

1. bouwmaterialen-, aardewerk- en glasindustrie;

4. metaalprodukten-, machine-, transportmiddelenindustrie en autoreparatiebedrijven;

8. papier- en papierwarenindustrie.

Tot de minst riskante groep horen de volgende bedrijfstakken:

17. transportbedrijven;

14. groot- en tussenhandel;

15. detailhandel;

9. grafische industrie, binderijen en uitgeverijen;

16. bank- en verzekeringswezen, exploitatie onroerende goederen en zakelijke dienstverlening.

De overige acht bedrijfstakken bevinden zich in de middengroep van gemiddelde risico's.

De aloude gedachte dat witte boorden-banen minder riskant zijn met betrekking tot het oplopen van beroepsziekten dan blauwe boorden-banen, wordt hierdoor slechts gedeeltelijk bevestigd: in de minst riskante groep van bedrijfstakken vinden wij ook blauwe boorden-bedrijfstakken, zoals de transportbedrijven en de grafische industrie, binderijen en uitgeverijen.

In tabel 3 worden de gemiddelde beroepsziekten per risicogroep van bedrijfstakken in zowel absolute als relatieve aantallen, per jaar van 1990 tot en met 1994 gepresenteerd.

(Tabel 3)

In de grafieken 1 tot en met 4 en 10 tot en met 13 wordt het verloop van de erkende beroepsziekten over de periode 1990-1993 in kaart gebracht. In grafiek 1 wordt het verloop in absolute aantallen in alle drie risicogroepen in een en dezelfde grafiek getoond. In grafiek 2 tot en met 4 wordt het verloop van de absolute aantallen per risicogroep van de bedrijfstakken afzonderlijk gepresenteerd. In grafiek 10 tot en met 13 wordt hetzelfde gedaan als in grafiek 1 tot en met 4, maar dan voor relatieve aantallen, dat wil zeggen incidenties per 100.000 werknemers in de betrokken bedrijfstakken. In de grafieken 5 en 14 wordt het verloop van alle beroepsziekten in totaal, opgeteld voor alle bedrijfstakken gezamenlijk, gepresenteerd. In grafiek 5 gebeurt dat in absolute aantallen en in grafiek 14 wederom voor relatieve aantallen.

Uit deze tien grafieken komt het volgende beeld naar voren. De incidentie van beroepsziekten neemt gestaag toe tussen 1990 en 1993. Dat geldt zowel in absolute aantallen als in relatieve aantallen, per 100.000 werknemers per bedrijfstak. Het dal in 1991 wordt mogelijk veroorzaakt door het feit, dat in Duitsland de effecten van de eenwording met de DDR gingen doorwerken in de statistieken voor beroepsziekten. Dat heeft ook gevolgen voor de transponatie van deze cijfers naar Nederland! De gestage toename van de incidentie van beroepsziekten geldt voor alle drie risicogroepen van bedrijfstakken, maar is het hoogste in de groep van meest riskante bedrijfstakken en het laagste in de groep van minst riskante bedrijfstakken. 
(Grafieken 5 en 14)

\subsection{Volume-ontwikkeling van arbeidsongevallen}

Vervolgens worden de ontwikkelingen in de arbeidsongevallen in beschouwing genomen. Wederom worden daartoe de achttien onderscheiden bedrijfstakken ingedeeld in drie groepen: groep 1 omvat de vijf bedrijfstakken met de hoogste aantallen arbeidsongevallen, groep 3 de vijf bedrijfstakken met de laagste aantallen arbeidsongevallen, en groep 2 de acht overblijvende bedrijfstakken met aantallen arbeidsongevallen die daar tussenin liggen. Groep 1 bevat dus de meest riskante bedrijfstakken, groep 2 de normaal-riskante bedrijfstakken en groep 3 de minst riskante bedrijfstakken. In tabel 4 worden de arbeidsongevallen absolute aantallen per risicogroep gepresenteerd (berekend als gemiddelde over vier jaren van 1990 tot en met 1993), in tabel 5 wordt datzelfde gedaan in relatieve aantallen, omgerekend naar aantallen per 100.000 werknemers werkzaam in de betrokken bedrijfstakken. Let wel dat de indeling in drie groepen bedrijfstakken naar afnemende risicograad met betrekking tot arbeidsongevallen niet dezelfde is als de eerdere groepsindeling naar afnemende risicograad ten opzichte van beroepsziekten!

(Tabellen 4 en 5)

Bezien wij eerst de incidentie van arbeidsongevallen in absolute aantallen, zoals weergegeven in tabel 4.

Tot de meest riskante groep horen de volgende bedrijfstakken:

13. bouwnijverheid- en installatiebedrijven;

17. transportbedrijven;

14. groot- en tussenhandel;

4. metaalprodukten-, machine-, transportmiddelenindustrie en autoreparatiebedrijven;

12. voedings- en genotsmiddelenindustrie.

Tot de minst riskante groep horen de volgende bedrijfstakken:

8. papier- en papierwarenindustrie;

1. bouwmaterialen-, aardewerk- en glasindustrie;

2. openbare nutsbedrijven;

11. textiel- en kledingindustrie;

10. leder-, schoen- e.a. lederwarenindustrie.

De overige acht bedrijfstakken bevinden zich in de middengroep van gemiddelde risico's.

De incidentie van arbeidsongevallen kan natuurlijk beter worden bezien in verhouding tot de omvang van de betrokken bedrijfstak, gemeten in aantallen werknemers die in die bedrijfstak werken. De gegevens naar relatieve aantallen worden in tabel 5 gepresenteerd. Tabel 5 levert de volgende resultaten op.

Tot de meest riskante groep horen de volgende bedrijfstakken:

13. bouwnijverheid en -installatiebedrijven;

3. basis metaalindustrie;

8. papier- en papierwarenindustrie;

7. hout- en meubelindustrie;

17. transportbedrijven.

Tot de minst riskante groep horen de volgende bedrijfstakken: 
5. elektrotechnische, instrumenten- en optische industrie;

9. grafische industrie, binderijen en uitgeverijen;

15. detailhandel;

16. bank- en verzekeringswezen, exploitatie onroerende goederen en zakelijke dienstverlening. 18 . gezondheidsdiensten en maatschappelijke dienstverlening.

De overige acht bedrijfstakken bevinden zich in de middengroep van gemiddelde risico's.

De veronderstelling dat witte boorden-banen minder riskant zijn met betrekking tot het betrokken raken bij arbeidsongevallen dan blauwe boorden-banen, wordt hierdoor gedeeltelijk bevestigd. In vergelijking met de bedrijfstakgebonden risico's op beroepsziekten (tabellen 1 en 2) zijn er echter ook verschillen. De basismetaalindustrie en de bouwnijverheid- en installatiebedrijven leveren grote risico's op voor zowel beroepsziekten als arbeidsongevallen. Werknemers in deze beide bedrijfstakken lopen dus dubbele risico's die groter zijn dan gemiddeld! De laagste risico's op zowel beroepsziekten als arbeidsongevallen worden gelopen in de grafische industrie, binderijen en uitgeverijen; de detailhandel; en het bank- en verzekeringswezen, exploitatie onroerende goederen en zakelijke dienstverlening. In de bouwmaterialen-, aardewerk- en glasindustrie; de metaalprodukten-, machine-, transportmiddelenindustrie en autoreparatiebedrijven; en de aardolie-, chemische en rubberindustrie zijn de risico's op beroepsziekten hoger. De risico's op arbeidsongevallen zijn weer hoger in de hout- en meubelindustrie; de bouwnijverheid en -installatiebedrijven; en in de transportbedrijven. De risico's op zowel beroepsziekten als bedrijfsongevallen zijn het laagst in de grafische industrie, binderijen en uitgeverijen; de detailhandel; en het bank- en verzekeringswezen, exploitatie onroerende goederen en zakelijke dienstverlening. Werknemers in deze drie bedrijfstakken lopen dus in beide opzichten lagere risico's dan gemiddeld! Met andere woorden: in sommige sectoren zijn de risico's op zowel beroepsziekten als arbeidsongevallen hoger respectievelijk lager dan gemiddeld, terwijl in ander sectoren hetzij de risico's op beroepsziekten hetzij de risico's op arbeidsongevallen hoger respectievelijk lager dan gemiddeld zijn.

In tabel 6 worden de gemiddelde arbeidsongevallen per risicogroep van bedrijfstakken in zowel absolute als relatieve aantallen, per jaar van 1990 tot en met 1994 gepresenteerd.

(Tabel 6)

In de grafieken 19 tot en met 22 en 28 tot en met 31 wordt het verloop van de arbeidsongevallen over de periode 1990-1993 in kaart gebracht. In grafiek 19 wordt het verloop in absolute aantallen in alle drie risicogroepen in een en dezelfde grafiek getoond; in de grafiek 20 tot en met 22 wordt het verloop van de absolute aantallen per risicogroep van de bedrijfstakken afzonderlijk gepresenteerd. In de grafiek 28 tot en met 31 wordt hetzelfde gedaan als in grafiek 19 tot en met 22, maar dan voor relatieve aantallen, dat wil zeggen incidenties per 100.000 werknemers in de betrokken bedrijfstakken. In de grafieken 23 en 32 wordt het verloop van alle arbeidsongevallen in totaal, opgeteld voor alle bedrijfstakken tezamen, gepresenteerd. Dat gebeurt in grafiek 23 in absolute aantallen en in grafiek 32 wederom voor relatieve aantallen.

Uit deze tweede serie van tien grafieken komt het volgende beeld naar voren. De incidentie van arbeidsongevallen neemt tussen 1990 en 1993 eerst af en daarna weer toe. In 1993 is veelal nagenoeg weer het niveau van 1990 bereikt. Dat geldt zowel in absolute aantallen als in relatieve aantallen, per 100.000 werknemers per bedrijfstak. Het dal in 1991 wordt mogelijk veroorzaakt door dezelfde omstandigheid als in het geval van beroepsziekten: in Duitsland gingen de effecten van de eenwording met de DDR in dat jaar doorwerken in de statistieken voor arbeidsongevallen. Dat heeft ook gevolgen voor de transponatie van deze cijfers naar de situatie in Nederland! De aanvankelijke daling en daarna weer toename van de incidentie van arbeidsongevallen geldt voor alle drie risicogroepen van bedrijfstakken, maar is het hoogste in de groep van meest riskante bedrijfstakken en het laagste in de groep van minst riskante bedrijfstakken.

(Grafieken 19 tot en met 22) 
(Grafieken 23 en 32)

\subsection{Prijs-ontwikkeling van beroepsziekten}

Na de ontwikkelingen in de volumecomponent (Q) dienen de ontwikkelingen in de prijscomponent (P) in kaart te worden gebracht. Wij hebben de prijscomponent van de totale schadelastuitkering van verzekeraars uit hoofde van verzekerde werkgeversaansprakelijkheid in ons theoretische causale model uitgesplitst in de volgende onderdelen:

a. kosten van gezondheidszorg (cure, behandeling en care, verzorging);

b. kosten van inkomensderving;

c. kosten van juridische bijstand;

d. kosten van smartegeld;

e. kosten van 'punitive damages';

Niet al deze kosten konden door ons worden berekend. Door mw H.W.J. van Dongen is gezondheidskundig onderzoek verricht naar de kosten van enkele specifieke beroepsziekten. In een intern verslag zijn ook de gehanteerde methodologie, de gemaakte keuzen en de noodzakelijke beperkingen van deze kostenberekening verantwoord. Van Dongen heeft een prijscomponent berekend die wij in dit deelrapport gebruiken. Deze prijscomponent bevat de volgende kostencomponenten:

-inkomstenderving, in nettobedragen (exclusief sociale premieheffing en belastingheffing) en als aanvulling bovenop de uitkering uit hoofde van sociale zekerheidsregelingen;

-inkomstenderving als gevolg van en voor de duur van omscholingsactiviteiten;

-smartegeld.

Let wel: in deze berekening zijn dus de kosten van juridische bijstand, van gezondheidszorg en van 'punitive damages' buiten beschouwing gelaten!

In bijlage 2 is de ontwikkeling in de gemiddelde kosten van beroepsziekten weergegeven. Deze ontwikkeling is berekend op basis van de kostenberekening voor 1 juni 1995, die is gepresenteerd door Van Dongen in haar stageverslag. De cijfers van voorgaande jaren hebben wij zelf berekend op basis van de prijsinflatiecijfers in procenten, zoals gepubliceerd door het CBS. Op deze wijze wordt een gemiddelde kostenontwikkeling voor beroepsziekten verkregen over de periode 1990-1995. Voor verdere informatie hebben wij verwezen naar de toelichting bij bijlage 2 en naar hoofdstuk $\mathrm{V}$ in dit onderzoeksrapport.

\subsection{Totale kosten-ontwikkeling van beroepsziekten}

$\mathrm{Nu}$ wij de afzonderlijke ontwikkelingen in de volumecomponent (Q) en in de prijscomponent (P) in kaart hebben gebracht, kan de ontwikkeling van de totale kosten (gedefinieerd als volume maal prijs, $\mathrm{Q} * \mathrm{P}$ ) over de periode 1990-1993 worden geanalyseerd. In de grafieken 38, 39, 41 en 42 worden de totale kostenontwikkelingen getoond voor beroepsziekten. De totale kostenontwikkeling van letsel door arbeidsongevallen kon niet worden berekend, omdat wij daarvan wel de volumecomponent maar niet de prijscomponent in kaart hebben kunnen brengen.

(Grafieken 38, 39, 41 en 42)

In grafiek 38 wordt de totale kostenontwikkeling van beroepsziekten, onderscheiden naar de drie risicogroepen van bedrijfstakken, gepresenteerd over de periode 1990-1993. Dit betreft absolute aantallen werknemers, terwijl in grafiek 41 dit wordt gedaan in relatieve aantallen werknemers, omgerekend naar 100.000 werknemers per bedrijfstak. In de grafiek 39 en 42 worden de totale kosten van de drie risicogroepen van bedrijfstakken bij elkaar opgeteld gepresenteerd. In grafiek 39 wordt de totale kostenontwikkeling in absolute zin getoond en in grafiek 42 weer in relatieve zin.

Alle risicogroepen laten een stijgende totale kostenontwikkeling zien, maar de hoogste risicogroep vertoont de grootste stijging. Wanneer de drie risicogroepen gezamenlijk worden genomen, 
zien wij in absolute zin de totale kosten voor beroepsziekten stijgen van ongeveer 65 miljoen in 1990 naar ongeveer 95 miljoen in 1993. Ook in relatieve zin stijgt in deze periode de totale kostenontwikkeling.

\section{Toekomstscenario's voor de periode tot 2005}

\subsection{Drie toekomstscenario's}

In deze paragraaf trekken wij de trendanalyse die hierboven is uitgevoerd voor de periode 1990-1993, door naar de toekomst, tot het jaar 2005. Een toekomstperiode van tien jaar, gerekend vanaf 1995, is nog overzienbaar. Er zijn verschillende mogelijkheden om een trendanalyse voor toekomstige ontwikkelingen uit te voeren. De eenvoudigste manier is om de trend uit het verleden domweg te extrapoleren. In feite wordt dan verondersteld dat de ontwikkelingen in het verleden zich onveranderd en in het zelfde tempo zullen voortzetten in de toekomst. Economen hebben daarvoor de bekende ceteris paribus-clausule bedacht: 'onder de conditie dat alle overige omstandigheden gelijk blijven'. Maar alle overige omstandigheden blijven niet altijd en zomaar gelijk, ceteris is niet altijd paribus. Daarom is het verstandiger om te werken met zogeheten 'toekomstscenario's', waarin verschillende trendontwikkelingen worden beschouwd in relatie tot specifieke veranderingen in een of meer determinanten van die ontwikkelingen.

Wij kiezen voor drie toekomstscenario's, waarbinnen toekomstige ontwikkelingen in de totale schadelast van verzekeraars uit hoofde van verzekerde werkgeversaansprakelijkheid voor beroepsziekten en arbeidsongevallen worden doorgerekend onder verschillende veronderstellingen wat betreft ontwikkelingen in determinanten van die schadelast. De ontwikkelingen in de determinanten van de schadelast (hetzij de volumecomponent, hetzij de prijscomponent, dan wel beide) kunnen worden uitgedrukt in zogeheten 'trendbreuken'.

Wij onderscheiden de volgende toekomstscenario's:

1. Het minimumscenario.

In dit scenario wordt verondersteld dat de trend uit het verleden zich ongewijzigd doorzet in de toekomst. Er komt geen verandering in een van de determinanten van de schadelast en er is geen sprake van een trendbreuk. De eenvoudige extrapolatie-methode is dan op zijn plaats.

2. Het middenscenario, in twee varianten.

In het middenscenario wordt wel een trendbreuk in een van de determinanten van de schadelast voorzien. De trend uit het verleden zet zich dan niet ongewijzigd voort en extrapolatie van de ontwikkeling in het verleden is niet zonder meer mogelijk.

Wij onderscheiden twee varianten van het midden scenario, A en B.

Middenscenario A.

In middenscenario A veronderstellen wij, dat de wetgeving op het terrein van de sociale zekerheid verder wordt versoberd in de richting van een collectief geregeld en verplicht basis- of minimumpakket (of basisinkomen), of een ministelsel. Dit zal een verschuiving met zich meebrengen van de kosten van beroepsziekten en arbeidsongeschiktheid, die nu nog voor een aanzienlijk gedeelte worden gedekt uit de publieke sociale zekerheidsfondsen, in de richting van verzekerde werkgeversaansprakelijkheid. Er zal dan immers een forse stijging plaats hebben van claims op deze verzekerde werkgeversaansprakelijkheid. Daardoor zal de toekomstige schadelast voor verzekeraars toenemen.

Middenscenario B.

In middenscenario B wordt verondersteld dat zich nieuwe beroepsziekten als OPS (het 'schilderssyndroom') en RSI (de 'toetsenbordenarm'), en letsels als gevolg van arbeidsongevallen zullen voordoen. Daardoor zal het aantal claims op verzekerde werkgeversaansprakelijkheid toenemen, waardoor de toekomstige schadelast voor verzekeraars zal stijgen. 
3. Het maximumscenario.

In het maximumscenario wordt verondersteld, dat beide trendbreuken zich zullen voordoen, en wel nagenoeg gelijktijdig: de sociale zekerheidswetgeving zal worden versoberd en nieuwe beroepsziekten en letsels door arbeidsongevallen zullen zich voordoen. Dat betekent een dubbele toename van het aantal claims en dus een dubbele toename van de toekomstige schadelast voor verzekeraars uit hoofde van verzekerde werkgeversaansprakelijkheid.

\subsection{Het minimumscenario}

In het minimumscenario zijn geen structurele veranderingen in de determinanten van de schadelast voor verzekeraars voorzien. Dat betekent dat wij zonder bedenkingen een eenvoudige extrapolatie van de trend over de periode 1990-1993 mogen uitvoeren tot het jaar 2005. Er zijn dan immers geen trendbreuken voorzien. In de grafieken 6 tot en met 9, 15 tot en met 18, 24 tot en met 27 en 33 tot en met 36 worden deze trendextrapolaties gepresenteerd. Daarbij is het eerder gemaakte onderscheid tussen riskante en minder riskante (groepen van) bedrijfstakken gehandhaafd. Daarnaast worden de trendextrapolaties van de totalen van alle bedrijfstakken tezamen gepresenteerd. De grafieken 6 tot en met 9 en 15 tot en met 18 betreffen de extrapolaties van de trends in beroepsziekten; de grafieken 24 tot en met 27 en 33 tot en met 36 die van de trends in arbeidsongevallen.

De grafiek 6 tot en met 9 geven de extrapolatie weer van de absolute aantallen beroepsziekten. In de grafieken 6 en 7 is het oorspronkelijke aanvangsjaar 1990 wel meegenomen; in de grafieken 8 en 9 is het jaar 1990 buiten beschouwing gelaten vanwege de statistische gevolgen de Duitse vereniging in 1991. In de grafieken 15 tot en met 18 worden de extrapolaties getoond van de relatieve aantallen beroepsziekten, per 100.000 werknemers in de betrokken bedrijfstakken. In de grafieken 15 en 16 is het jaar 1990 wel mee in beschouwing genomen; in de grafiek 17 en 18 is dat jaar buiten beschouwing gelaten.

Zowel absoluut als relatief neemt de incidentie van beroepsziekten tot het jaar 2005 fors toe, variërend van een factor 3 tot een factor 6 in absolute zin (zie grafiek 7 en 9) en van een factor 2,5 tot eveneens een factor 6 in relatieve zin (zie grafieken 16 en 18). Wanneer het jaar 1990 buiten beschouwing wordt gelaten, is de voorziene trendstijging enigszins groter dan wanneer dat jaar wel wordt meegenomen in de extrapolatie.

\section{(Grafieken 6 tot en met 9)}

(Grafieken 15 tot en met 18)

De grafieken 24 tot en met 27 geven de extrapolatie weer van de absolute aantallen arbeidsongevallen. In de grafieken 24 en 25 is het jaar 1990 wel meegenomen. In de grafieken 26 en 27 is dit jaar 1990 buiten beschouwing gelaten (wederom vanwege de statistische effecten van de Duitse vereniging in 1991). In de grafieken 33 tot en met 36 worden de extrapolaties getoond van de relatieve aantallen beroepsziekten, per 100.000 werknemers in de betrokken bedrijfstakken. In de grafieken 33 en 34 is het jaar 1990 meegenomen, in de grafieken 35 en 36 is dat jaar weer buiten beschouwing gelaten.

In absolute zin neemt de incidentie van arbeidsongevallen tot het jaar 2005 toe, zij het dat deze toename gematigd is wanneer 1990 mede in beschouwing wordt genomen (grafiek 25), doch zeer fors wanneer 1990 buiten beschouwing wordt gelaten (grafiek 27). In dat laatste geval is sprake van meer dan een verdubbeling van 4000 ongevallen in het jaar 1991 tot 9000 ongevallen in het jaar 2005! Wanneer de incidentie van arbeidsongevallen wordt gerelateerd aan de omvang van de respectievelijke bedrijfstakken (per 100.000 werknemers), ontstaat een ander beeld. Wanneer het jaar 1990 in de analyse wordt meegenomen, is sprake van een lichte daling van de incidentie van 110 naar minder dan 90 ongevallen (grafiek 34). Wanneer dat jaar 1990 niet in de analyse wordt meegenomen, is sprake van een verdubbeling van de incidentie van 100 ongevallen in het jaar 1991 tot 200 ongevallen in het jaar 2005.

(Grafieken 24 tot en met 27) 
(Grafieken 33 tot en met 36)

Kijken wij vervolgens naar de prijsontwikkeling voor beroepsziekten, dan wordt die getoond in grafiek 37. De gemiddelde kosten per geval voor beroepsziekten stijgen in het minimumscenario van ongeveer hfl. 48.500.- in 1990 naar ongeveer hfl. 78.000.- in 2005. De prijsontwikkeling van letsels als gevolg van arbeidsongevallen hebben wij niet in kaart kunnen brengen, omdat de daarvoor benodigde initiële gegevens voor de periode 1990-1993 niet voorhanden zijn, zoals hierboven reeds gememoreerd.

\section{(Grafiek 37)}

Wij kunnen nu de totale kostenontwikkeling met betrekking tot beroepsziekten voor de periode 19902005 berekenen middels trendextrapolatie. In de grafiek 40 wordt deze totale kostenontwikkeling getoond in absolute cijfers en in grafiek 43 in relatieve cijfers, per 100.000 werknemers in de bedrijfstak. In absolute zin stijgen de totale kosten voor beroepsziekten van ongeveer 58 miljoen in 1990 naar ongeveer 259 miljoen in 2005. Dit betekent een bijna verviereneenhalfvoudiging (zie tabel 7)! Een vergelijkbare stijging doet zich voor in relatieve zin, naar verhouding van de omvang van de bedrijfstakken (gemeten in 100.000-tallen werknemers.

(Grafieken 40 en 43)

Tabel 7 Ontwikkeling absolute kosten van beroepsziekten, 1990-2005 (in miljoenen guldens), volgens minimumscenario

$$
\begin{aligned}
& \text { minimum- } \\
& \text { scenario }
\end{aligned}
$$

$\begin{array}{rr}1990 & \mathbf{5 8} \\ 1991 & 67 \\ 1992 & \mathbf{7 7} \\ 1993 & \mathbf{8 8} \\ 1994 & 99 \\ 1995 & 111 \\ 1996 & 123 \\ 1997 & 136 \\ 1998 & 149 \\ 1999 & 162 \\ 2000 & 176 \\ 2001 & 191 \\ 2002 & 207 \\ 2003 & 224 \\ 2004 & 241 \\ 2005 & 259\end{array}$

\subsection{Twee middenscenario's}

Middenscenario A

In middenscenario A veronderstellen wij een trendbreuk als gevolg van drastische versobering van de sociale zekerheidswetgeving, bijvoorbeeld door invoering van een basispakket, een ministelsel of een basisinkomen. Dat heeft twee effecten voor de verzekeraars van werkgeversaansprakelijkheid voor 
beroepsziekten en arbeidsongevallen. Er zullen meer claims worden gelegd en er zullen hogere claims worden gelegd. Niet alle risico's worden meer gedekt door de publieke sociale zekerheidsregelingen en niet het volledige risico zal meer worden gedekt. Zowel langs de prijscomponent als langs de volumecomponent zal de totale kostenontwikkeling, en dus de totale schadelast van de verzekeraars, toenemen.

Als wij veronderstellen dat één en ander in een klap wordt ingevoerd, met een voorbereidingstijd van vijf jaar (en met een bepaalde overgangstijd), zou gerekend vanaf 1995 in het jaar 2000 een schokeffect zichtbaar moeten zijn. In 2000 zou een eenmalige opwaartse trendbreuk in de extrapolatie van de totale kostenontwikkeling voor beroepsziekten, zoals gepresenteerd in grafieken 40 en 43 , moeten worden verwerkt. De vraag is evenwel hoe groot deze opwaartse trendbreuk zou kunnen zijn. Ook hier kan alleen met veronderstellingen worden gewerkt. Wij hanteren de volgende veronderstellingen:

1. plotselinge verandering van het sociale zekerheidsstelsel in het jaar 2000;

2. met een eenmalig schokeffect, zonder naijlingseffecten en zonder tweede of derde orde-effecten; 3. met als gevolg een verdubbeling van de totale kosten voor beroepsziekten voor elk jaar vanaf 2000 tot en met 2005 (via zowel de volumecomponent als gelijktijdig de prijscomponent).

In het jaar 2000 verdubbelen dan plotseling de totale kosten voor beroepsziekten in absolute zin van ongeveer 176 miljoen (de oorspronkelijke extrapolatie in grafiek 40) tot ongeveer 352 miljoen, om in het jaar 2005 uit te komen op een verdubbeling van ongeveer 259 miljoen tot ongeveer 518 miljoen (zie tabel 8).

Tabel 8 Ontwikkeling absolute kosten van beroepsziekten, 1990-2005

(in miljoenen guldens), volgens middenscenario A:

verdubbeling vanaf 2000

$$
\begin{array}{ll}
\text { minimum- } & \text { midden- } \\
\text { scenario } & \text { scenario A }
\end{array}
$$

$\begin{array}{rrr}1990 & \mathbf{5 8} & \\ 1991 & 67 & \\ 1992 & \mathbf{7 7} & \\ 1993 & \mathbf{8 8} & \\ 1994 & 99 & \\ 1995 & 111 & \\ 1996 & 123 & \\ 1997 & 136 & \mathbf{3 5 2} \\ 1998 & 149 & \mathbf{3 8 2} \\ 1999 & 162 & 414 \\ 2000 & 176 & 448 \\ 2001 & 191 & \mathbf{4 8 2} \\ 2002 & 207 & \mathbf{5 1 8} \\ 2003 & 224 & \\ 2004 & 241 & \\ 2005 & 259 & \end{array}$

\section{Middenscenario B}

In middenscenario B veronderstellen wij een trendbreuk als gevolg van het ontstaan van nieuwe beroepsziekten en letsels als gevolg van arbeidsongevallen. Voorbeelden zijn OPS (het 'schilderssyndroom') en RSI (de 'toetsenbordenarm'). De ontwikkeling van nieuwe beroepsziekten en letsels is nooit uitgesloten. Daarbij spelen vele factoren een rol: economisch-technologische factoren (welke nieuwe bedrijfsactiviteiten en beroepen ontwikkelen zich?), gezondheidskundige factoren (welke nieuwe 
beroepsziekten en letsels worden medisch erkend?) en juridische factoren (wordt de causaliteitsgrond juridisch geaccepteerd?). Wij hanteren de volgende veronderstellingen:

1. een geleidelijk ontstaan van deze ziekten en letsels, met ingang van 1995;

2. met een geleidelijk effect met ingang van 1996;

3. met als gevolg een toename van de totale kosten voor beroepsziekten en arbeidsongevallen per jaar vanaf 1996 tot en met 2005 via de volumecomponent (de prijscomponent wordt verondersteld de trendextrapolatie te volgen), met $10 \%$ per jaar.

In 1996 nemen de totale kosten voor verzekeraars voor beroepsziekten in absolute zin dan toe van 123 miljoen (volgens de oorspronkelijke extrapolatie in grafiek 40) tot 135 miljoen (plus 10\%). Uit tabel 9 blijkt een stijging in het jaar 2000 van 176 miljoen tot 200 miljoen, om in het jaar 2005 uit te komen van oorspronkelijk 259 miljoen op 319 miljoen (plus $23,2 \%$, als gevolg van de samengestelde interestregel bij $10 \%$ groei per jaar over een periode van 10 jaar)!

Tabel 9 Ontwikkeling absolute kosten van beroepsziekten, 1990-2005

(in miljoenen guldens), volgens middenscenario B:

$10 \%$ stijging vanaf 1996

$\begin{array}{lll}\text { minimum- } & \text { midden- } & \text { midden- } \\ \text { scenario } & \text { scenario A } & \text { scenario B }\end{array}$

$\begin{array}{cccc}1990 & \mathbf{5 8} & & \\ 1991 & 67 & & \\ 1992 & \mathbf{7 7} & & \\ 1993 & 88 & & \\ 1994 & 99 & & 135 \\ 1995 & 111 & & 149 \\ 1996 & 123 & & 164 \\ 1997 & 136 & & 180 \\ 1998 & 149 & 352 & 198 \\ 1999 & 162 & 382 & 218 \\ 2000 & 176 & 414 & 240 \\ 2001 & 191 & 448 & 290 \\ 2002 & 207 & 482 & 319 \\ 2003 & 224 & \mathbf{5 1 8} & \\ 2004 & 241 & & \\ 2005 & 259 & & \end{array}$

\subsection{Het maximumscenario}

In het maximumscenario worden de beide afzonderlijke trendbreuken van beide middenscenario's gecombineerd, onder de daarbij gehanteerde veronderstellingen. Het ontstaan van nieuwe beroepsziekten en letsels door arbeidsongevallen heeft reeds vanaf 1996 effecten. Wij hebben in middenscenario B verondersteld, dat deze trendbreuk leidt tot een $10 \%$ extra kostenstijging vanaf 1996 . In middenscenario A hebben wij verondersteld, dat de radicale versobering van het sociale zekerheidsstelsel zich doet gelden vanaf het jaar 2000, met als gevolg een verdubbeling vanaf dat jaar van de totale kosten. In 1996 doet zich dus de trendbreuk voor zoals beschreven in middenscenario B; daarbovenop komt de trendbreuk zoals beschreven in middenscenario A. Dit heeft de volgende consequenties voor de ontwikkeling van de totale kosten voor beroepsziekten in absolute zin (tabel 10).

Uit deze tabel 10 blijkt, dat de totale kosten voor beroepsziekten voor de verzekeraars zullen stijgen van 111 miljoen in 1995 via 396 miljoen in het jaar 2000 tot liefst 638 miljoen in het jaar 2005 . 
Het grootste effect gaat uit van de tweede trendbreuk (de verdubbeling van de totale kosten vanaf het jaar 2000), vanwege de veronderstelde omvang van de trendbreuk en vanwege het veronderstelde plotselinge ontstaan. Ook van de eerste trendbreuk (een $10 \%$ stijging van de totale kosten vanaf het jaar 1996), gaat een substantieel, zij het kleiner effect uit, vanwege de veronderstelde omvang van de trendbreuk en vanwege het veronderstelde graduele ontstaan.

Tabel $10 \quad$ Ontwikkeling absolute kosten van beroepsziekten, 1990-2005

(in miljoenen guldens), volgens maximumscenario:

$10 \%$ stijging vanaf 1996 plus verdubbeling vanaf 2000

$\begin{array}{llll}\text { minimum- } & \text { midden- } & \text { midden- } & \text { maximum- } \\ \text { scenario } & \text { scenario A } & \text { scenario B } & \text { scenario }\end{array}$

$\begin{array}{lrrrr}1990 & \mathbf{5 8} & & & \\ 1991 & 67 & & & \\ 1992 & \mathbf{7 7} & & & \\ 1993 & \mathbf{8 8} & & & \\ 1994 & 99 & & 135 & 135 \\ 1995 & 111 & & 149 & 149 \\ 1996 & 123 & & 164 & 164 \\ 1997 & 136 & & 180 & 180 \\ 1998 & 149 & 352 & 198 & 396 \\ 1999 & 162 & 382 & 218 & 436 \\ 2000 & 176 & 414 & 240 & 480 \\ 2001 & 191 & 448 & 264 & \mathbf{5 2 8} \\ 2002 & 207 & 482 & 290 & \mathbf{5 8 0} \\ 2003 & 224 & \mathbf{5 1 8} & \mathbf{3 1 9} & 638 \\ 2004 & 241 & & & \end{array}$

\section{Conclusies en kanttekeningen}

In dit deelrapport hebben wij een economische analyse gepresenteerd van de ontwikkeling van de totale kosten van verzekeraars als gevolg van schade-uitkeringen uit hoofde van werkgeversaansprakelijkheid voor beroepsziekten en arbeidsongevallen. Uit deze analyse hebben wij enkele conclusies getrokken, die wij hieronder nog een keer samenvatten.

1. Er zijn grote verschillen in risicograad voor beroepsziekten en voor arbeidsongevallen tussen drie onderscheiden groepen van bedrijfstakken. Bovendien vertonen sommige bedrijfstakken meer risico's voor beroepsziekten en sommige meer voor arbeidsongevallen. Slechts enkele bedrijfstakken vertonen voor beide schade-oorzaken hoge risico's en slechts enkele andere bedrijfstakken vertonen voor beide lage risico's.

2. Het aantal claims voor beroepsziekten zal in de periode 1990 tot en met 2005 relatief snel toenemen. Bovendien zal in deze periode deze toename relatief sneller zijn dan de toename van het aantal claims voor bedrijfsongevallen.

3. Bij ongewijzigde omstandigheden (minimumscenario) zal de totale schadelastontwikkeling voor verzekeraars in de periode 1990-2005 snel toenemen, vooral als gevolg van de volumecomponent in de totale kostenontwikkeling en minder als gevolg van de prijscomponent daarin. 
4. Wanneer zich trendbreuken voordoen (volgens middenvariant A of B), zal deze totale schadelastontwikkeling voor verzekeraars in de periode 1990-2005 nog sneller toenemen.

5. Wanneer zich beide trendbreuken (van middenvariant A en B) in de periode 1990-2005 zullen voordoen (maximumvariant), zal deze totale schadelastontwikkeling voor verzekeraars in deze periode nog weer sneller toenemen.

Bij deze economische analyse en bij de daaruit getrokken conclusies dienen echter enkele belangrijke kanttekeningen te worden geplaatst. Deze kanttekeningen zijn vooral onderzoekstechnisch en methodologisch van aard. De beschikbaarheid van de data, die nodig zijn om het causaal model, de trendanalyse en de scenario-analyse in te vullen was zeer beperkt. Dit heeft de nodige consequenties.

1. Data waren niet beschikbaar voor Nederland, maar alleen in voldoende mate voor Duitsland. Deze data moesten naar de Nederlandse situatie worden vertaald (transponatie). Dit op basis van de beruchte ceteris paribus-clausule. Wanneer ceteris niet paribus is, hebben wij een groot probleem. Gepoogd is in elk geval te standaardiseren voor de bedrijfstakomvang (gemeten in procenten van de beroepsbevolking, werkzaam in de betrokken bedrijfstak). De tabellen met gegevens in relatieve aantallen geven daarom waarschijnlijk een waarheidsgetrouwer beeld dan die met gegevens in absolute aantallen.

2. Data waren slechts beschikbaar voor een viertal jaren, 1990-1993. Op slechts vier meetpunten een trendanalyse voor een langere periode berekenen is een hachelijke zaak (korte geschiedenis in combinatie met lange toekomst). Eenmalige uitbijters in een jaar kunnen dan grote effecten op de trend hebben. Daardoor is de scenario-analyse, waarbij tien jaar, tot en met het jaar 2005 wordt geëxtrapoleerd, evenzeer een riskante zaak, waarbij het nodige voorbehoud moet worden gemaakt.

3. Voor de meeste onafhankelijke en interveniërende variabelen in het causale model waren geen tijdreeksen beschikbaar. Dat betekent dat het causale model niet kon worden vertaald in een regressiemodel. De trendanalyse is gebaseerd op een regressiemodel waarin de afhankelijke variabele (de schadelast) en de samenstellende deelvariabelen daarvan (de prijsontwikkeling en de volumeontwikkeling) slechts zijn gerelateerd aan de tijdcomponent (de jaartallen 1990-1993). Dat betekent een grote versimpeling van de regressie-analyse. Helaas stond de beperkte beschikbaarheid van de data ons geen andere methode toe.

4. De omvang van de schokeffecten, die door trendbreuken worden veroorzaakt, is op basis van heroïsche veronderstellingen berekend. Dat heeft grote consequenties voor de diverse scenario-analyses. Andere veronderstellingen over de omvang van de schokeffecten leiden tot andere uitkomsten. In plaats van een 'educated guess' ware een steviger onderbouwing gewenst. Dat geldt, zij het in wat mindere mate, misschien ook voor de keuze van de oorzaken van de trendbreuken en voor de keuze van de timing ervan. Uitvoering van een zogeheten 'gevoeligheidsanalyse' is dan een mogelijkheid om te bezien, hoe gevoelig de uitkomsten van de drie scenario's zijn voor veranderingen in de veronderstellingen omtrent de trendbreuken. 


\section{Bijlage Onderzoek Werkgeversaansprakelijkheid}

Statistische verwerking van Beroepsziekten en Arbeidsongevallen in Nederland aan de hand van Duitse data 1990 - 1993

Datum van verwerking: 17 juli 1995 


\section{Opzet en veronderstellingen}

In dit deel van het onderzoek zal de statistische verwerking van de gegevens plaatsvinden, die bij het gezondheidswetenschappelijk deel gevonden zijn. Dit zal gebeuren aan de hand van Duitse data, die aangepast zijn aan de Nederlandse situatie.

Er zijn data beschikbaar voor 18 verschillende bedrijfstakken. Deze zullen steeds opgedeeld worden in drie verschillende groepen. De eerste groep is de groep waar de meeste gevallen van beroepsziekten, respectievelijk arbeidsongevallen voorkomen. Deze groep bestaat uit vijf bedrijfstakken.

De tweede groep is de middengroep. Hierin zijn acht bedrijfstakken vertegenwoordigd, die een gemiddeld aantal arbeidsongevallen, respectievelijk beroepsziekten kennen.

De derde groep is de voor de verzekeraars relatief gunstigste groep; dit is natuurlijk de groep waar het minst aantal arbeidsongevallen, respectievelijk beroepsziekten voorkomen.

De statistische verwerking bestaat uit vijf verschillende gedeelten:

* analyse van absoluut aantal beroepsziekten;

* analyse van relatief aantal beroepsziekten;

* analyse van absoluut aantal arbeidsongevallen;

* $\quad$ analyse van relatief aantal arbeidsongevallen;

* $\quad$ analyse van de kosten - en prijskomponent van beroepsziekten.

Bij alle onderdelen zal er zowel gekeken worden naar de totale hoeveelheids- c.q. kostenkomponent, als ook naar de komponenten van de verschillende groepen. Belangrijk is hierbij op te merken, dat per onderdeel de samenstelling van de groepen zal veranderen. Het kan namelijk zo zijn, dat een bedrijfstak een hoog aantal absolute beroepsziekten kent, terwijl het relatieve aantal door de grootte van de sector relatief laag is. De bedrijfstakken zijn daarom genummerd (zie Bijlage I) en worden in de statistische verwerking steeds met dit nummer aangeduid.

Bij alle analyses is er ook een schatting gemaakt van de te verwachte aantallen, respectievelijk kosten. Hierbij is de assumptie gemaakt, dat de trend van het verleden zich doorzet in de toekomst en wordt er geen rekening gehouden met trendbreuken.

Bij de berekening van de kostenkomponent is er rekening gehouden met inflatie (zie Bijlage II), die ook voor de toekomst is geschat m.b.v. trendanalyse. 


\section{Bijlage 1}

\begin{tabular}{||l|l||}
\hline branche & economische activiteit \\
\hline 1 & bouwmaterialen-, aardewerk- en glasindustrie \\
2 & openbare nutsbedrijven \\
3 & basis metaalindustrie \\
4 & metaalprodukten-, machine-, transportmiddelenindustrie en auto- \\
& reparatiebedrijven \\
5 & elektrotechnische, instrumenten- en optische industrie \\
6 & aardolie-, chemische- en rubberindustrie \\
7 & hout- en meubelindustrie \\
8 & papier- en papierwarenindustrie \\
9 & grafische industrie, binderijen en uitgeverijen \\
10 & leder-, schoen- e.a. lederwarenindustrie \\
11 & textiel -en kledingindustrie \\
12 & voedings- en genotsmiddelenindustrie en horeca \\
13 & bouwnijverheid en -installatiebedrijven \\
14 & groot- en tussenhandel \\
15 & detailhandel \\
16 & bank- en verzekeringswezen, exploitatie onroerende goederen en \\
17 & zakelijke dienstverlening \\
18 & transportbedrijven \\
& gezondheidsdiensten en maatschappelijke dienstverlening \\
\hline \hline
\end{tabular}

\section{Bijlage II}

\begin{tabular}{||l|l|l||}
\hline jaar & inflatiecijfers in \% & gemiddelde kosten beroepsziekten* \\
\hline 1990 & 2.9 & $48.921,08$ \\
1991 & 3.5 & $50.339,79$ \\
1992 & 4.5 & $52.101,68$ \\
1993 & 3.2 & $54.446,26$ \\
1994 & 1.75 & $56.188,54$ \\
1995 & 1 & $57.171,84$ \\
\hline
\end{tabular}

gemiddelde geschatte kosten per claim op 1 juni 1995 in Nederland:

\section{Fl 57.171,84}

* N.B. De cijfers zijn berekend aan de hand van de kosten van $67 \%$ van het totaal aantal beroepsziekten in 1993. 


\section{deel 1 \\ analyse absoluut aantal beroepsziekten}


groep 1: gemiddeld 132 tot 384 beroepsziekten per jaar, van het totaal aantal werknemers in de bedrijfstak

groep 2: gemiddeld 17 tot 57 beroepsziekten per jaar, van het totaal aantal werknemers in de bedrijfstak

groep 3: gemiddeld 2 tot 18 beroepsziekten per jaar, van het totaal aantal werknemers in een bedrijfstak

\begin{tabular}{|c|c|c|}
\hline groep 1 & groep 2 & groep 3 \\
\hline $18,13,4,12,6$ & $17,14,3,5,15,1,7,16$ & $8,11,2,9,10$ \\
\hline
\end{tabular}

Tabel 1: bedrijfstakken ingedeeld naar absoluut aantal erkende beroepsziekten per jaar; van 1990 tot en met 1993

\begin{tabular}{|r|r|r|r|r|r|r||}
\hline bedrijfstak & groep & $\mathbf{1 9 9 0}$ & $\mathbf{1 9 9 1}$ & $\mathbf{1 9 9 2}$ & $\mathbf{1 9 9 3}$ & gemiddelde \\
\hline \hline 18 & 1 & 374 & 373 & 453 & 334 & 383.50 \\
\hline 13 & 1 & 208 & 178 & 179 & 267 & 208.00 \\
\hline 4 & 1 & 170 & 133 & 198 & 321 & 205.50 \\
\hline 12 & 1 & 178 & 49 & 124 & 187 & 134.50 \\
\hline 6 & 1 & 106 & 105 & 124 & 194 & 132.25 \\
\hline 17 & 2 & 59 & 49 & 43 & 76 & 56.75 \\
\hline 14 & 2 & 34 & 41 & 39 & 45 & 39.75 \\
\hline 3 & 2 & 24 & 37 & 31 & 65 & 39.25 \\
\hline 5 & 2 & 31 & 26 & 34 & 41 & 33.00 \\
\hline 15 & 2 & 38 & 20 & 31 & 38 & 31.75 \\
\hline 1 & 2 & 27 & 20 & 29 & 38 & 28.50 \\
\hline 7 & 2 & 24 & 16 & 24 & 36 & 25.00 \\
\hline 16 & 2 & 10 & 18 & 19 & 24 & 17.75 \\
\hline 8 & 3 & 16 & 10 & 20 & 24 & 17.50 \\
\hline 11 & 3 & 13 & 9 & 12 & 19 & 13.25 \\
\hline 2 & 3 & 7 & 6 & 9 & 9 & 7.75 \\
\hline 9 & 3 & 6 & 6 & 8 & 10 & 7.50 \\
\hline 10 & 3 & 3 & 2 & 2 & 2 & 2.25 \\
\hline & & & & & & $\mathbf{1 3 8 4 . 2 5}$ \\
\hline & & $\mathbf{1 3 2 8}$ & $\mathbf{1 0 9 8}$ & $\mathbf{1 3 8 0}$ & $\mathbf{1 7 3 1}$ & \\
\hline totaal & & & & & \\
\hline & & & & & & \\
\hline
\end{tabular}

Grafiek 1: absoluut aantal erkende beroepsziekten 
grafiek 2: absoluut aantal beroepsziekten - groep 1
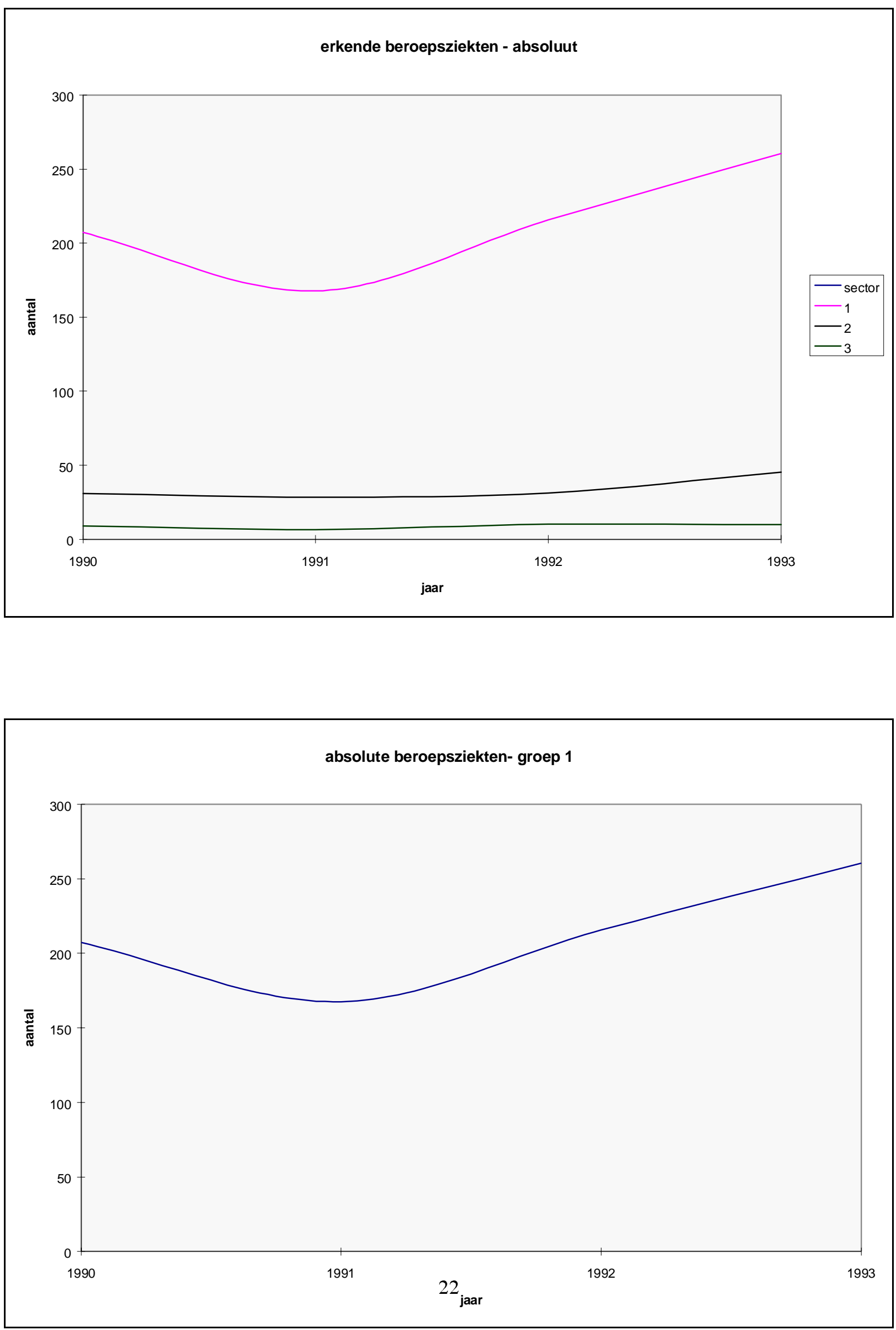
Grafiek 3: absoluut aantal beroepsziekten - groep 2

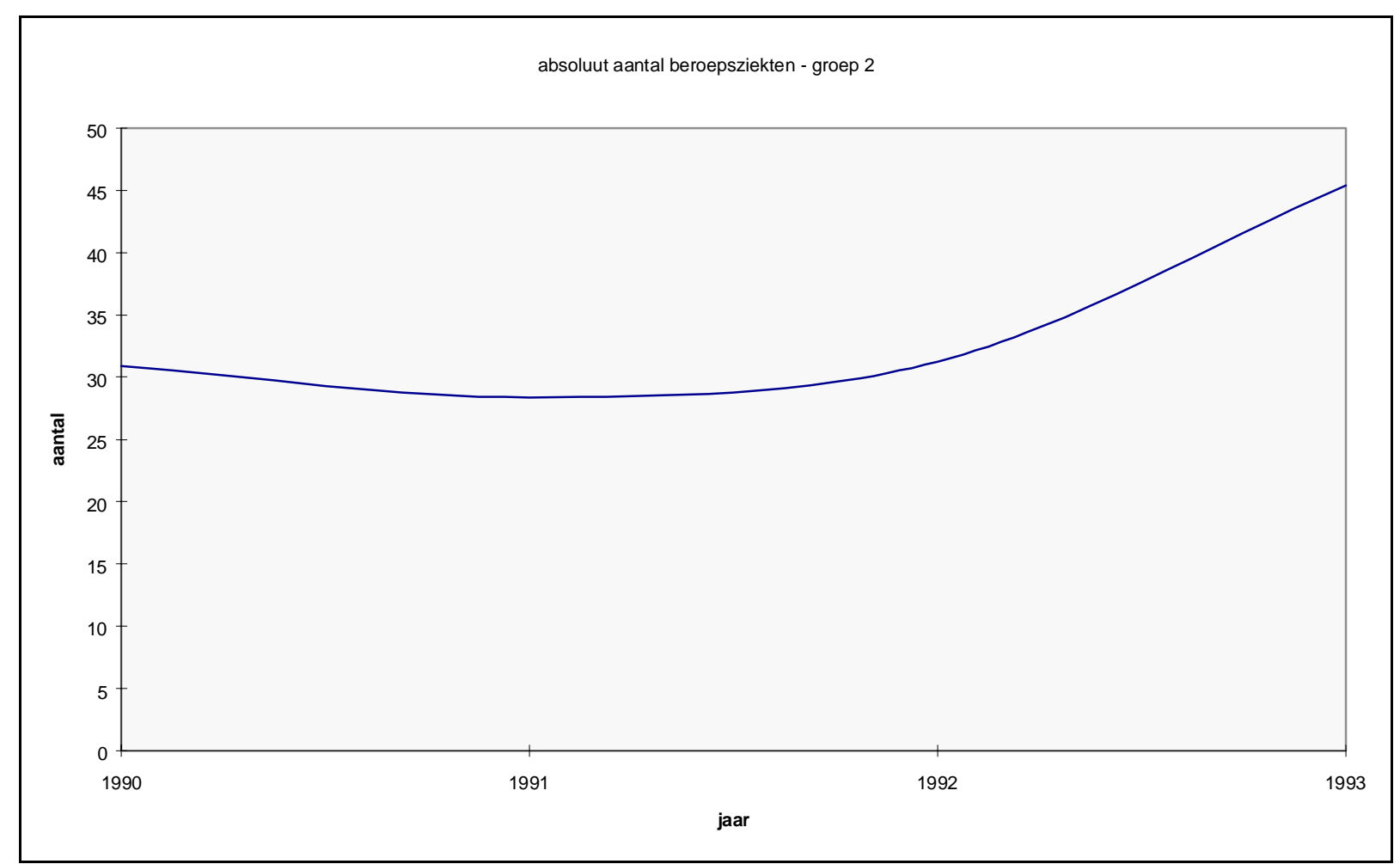

Grafiek 4: absoluut aantal beroepsziekten - groep 3

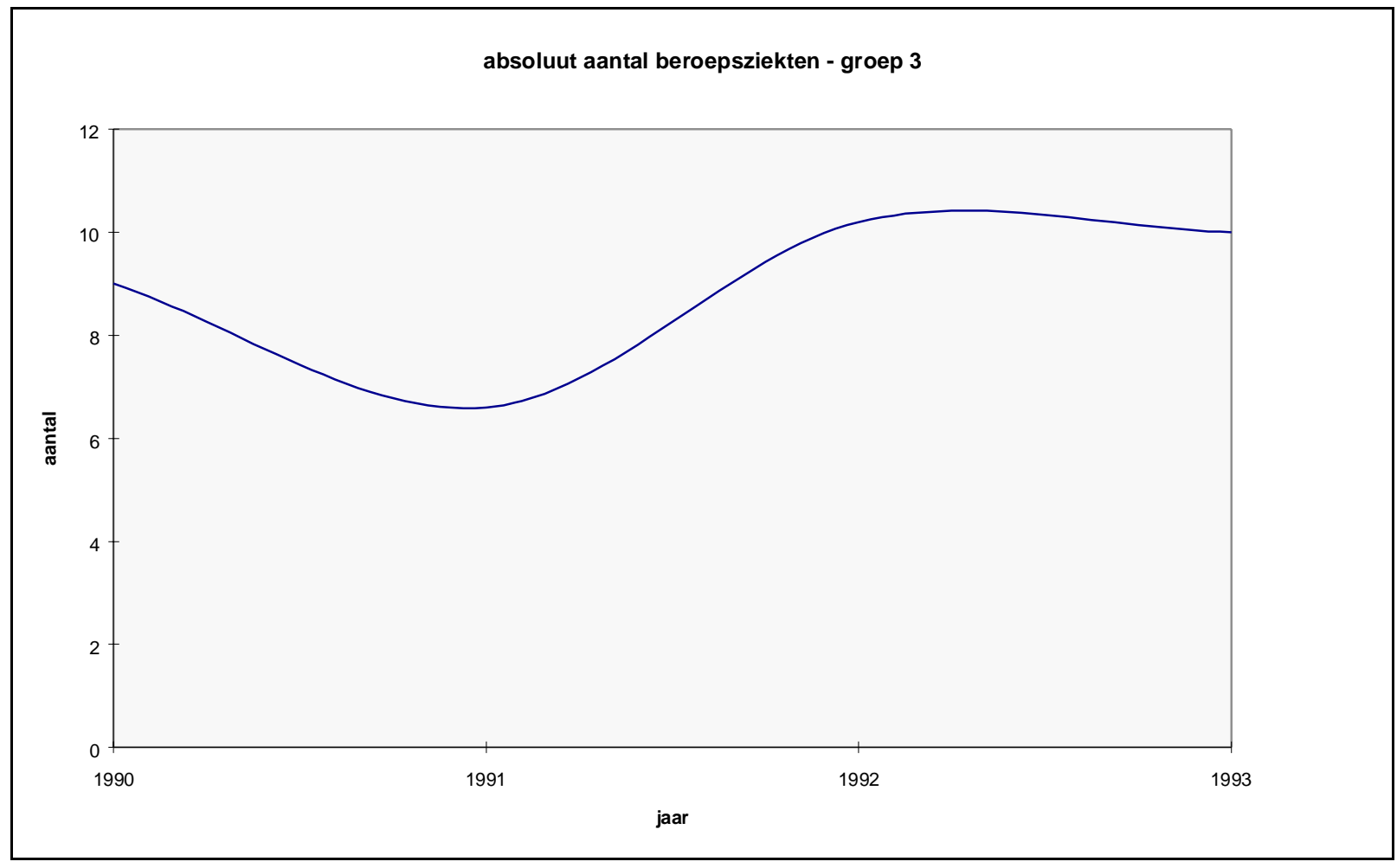




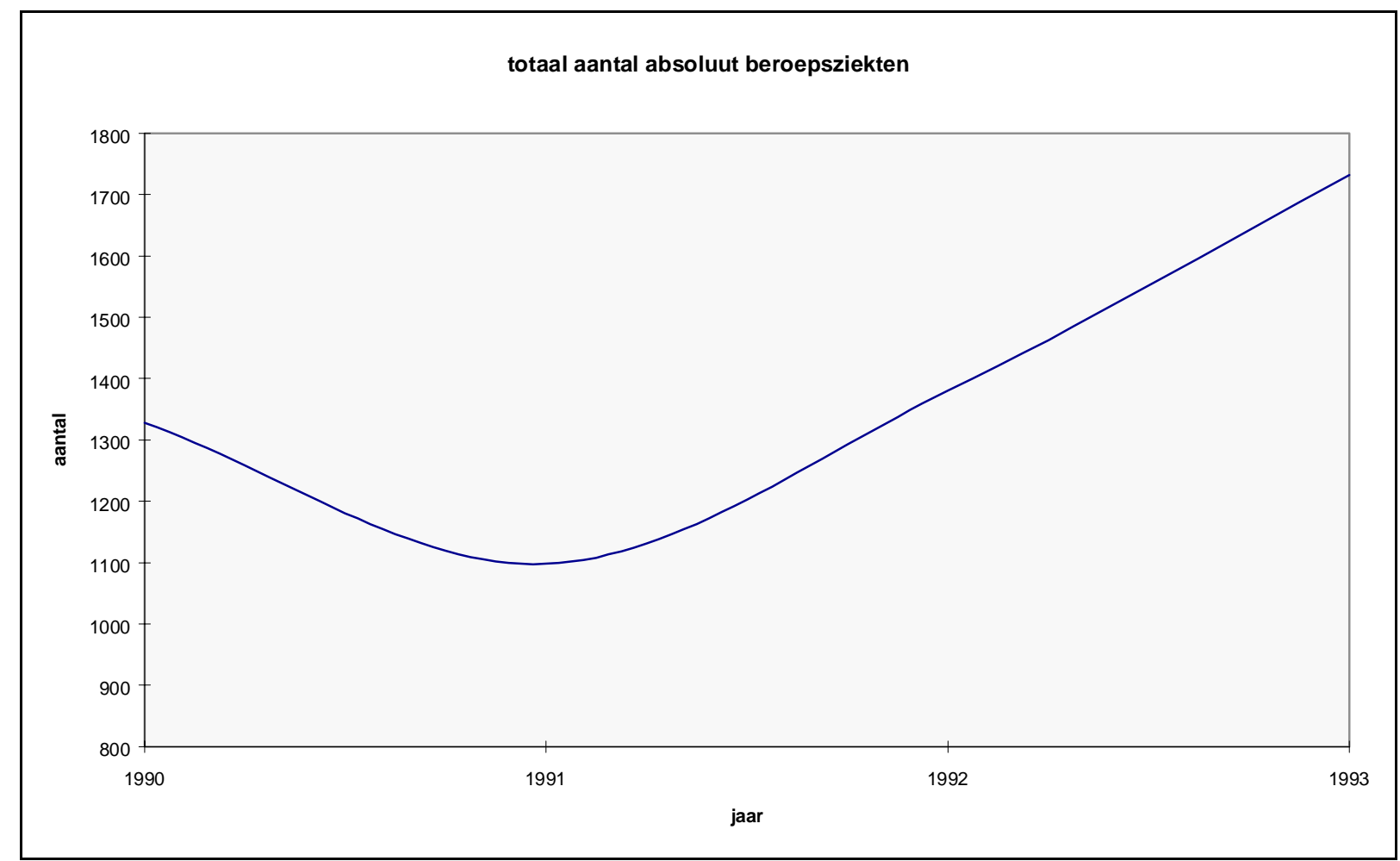

Grafiek 5: totaal aantal absolute beroepsziekten 


\section{TRENDANALYSE ABSOLUUT AANTAL BEROEPSZIEKTEN}

Grafiek 6: schatting van absoluut aantal beroepsziekten in de toekomst

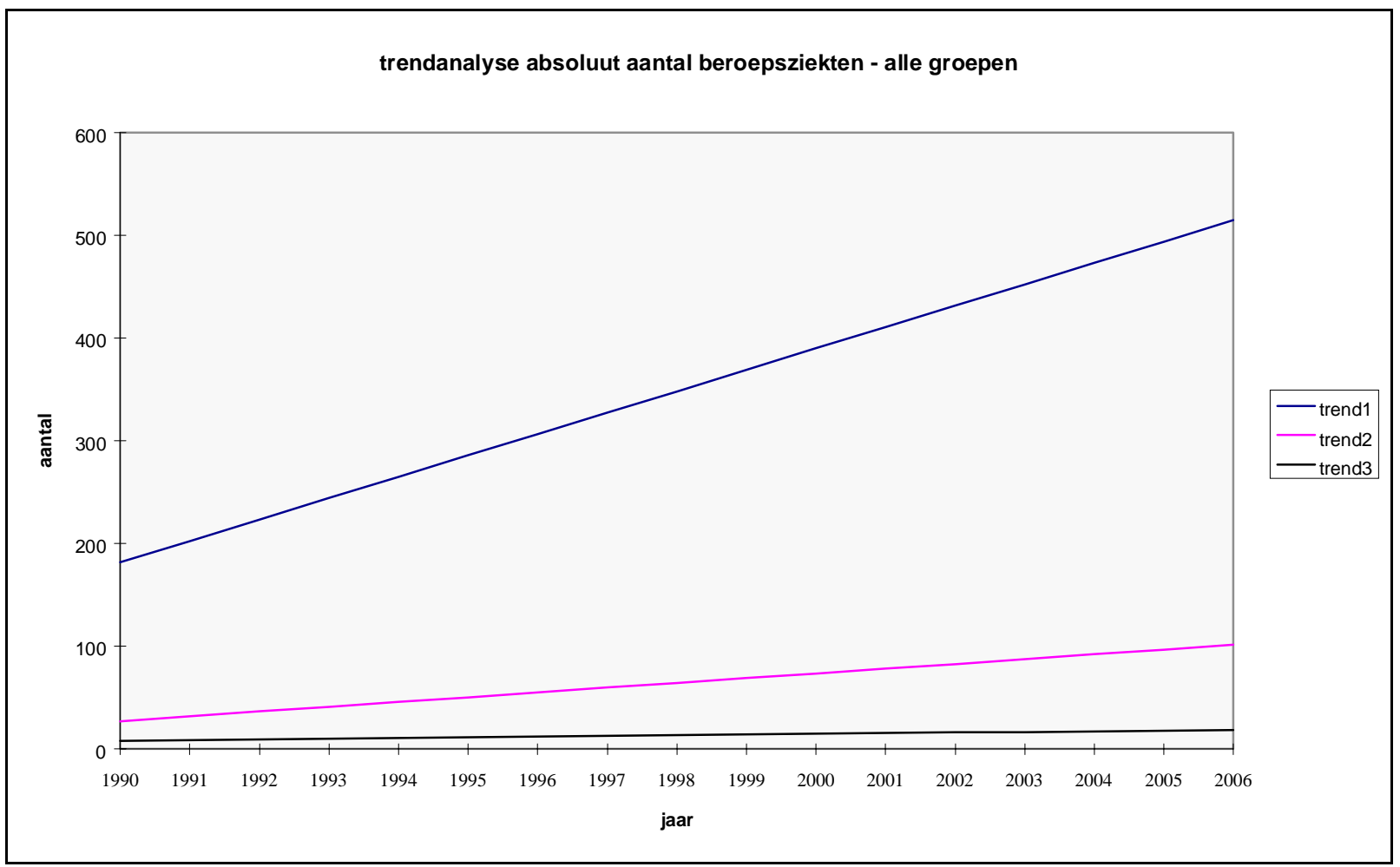

m.b.v. trendanalyse (1990 - 1993) ; alle groepen

groep 1: $\mathrm{Q}=-41250,3+0,66 *$ jaar totaal: $\mathrm{Q}=-295548+149,1 *$ jaar

groep 2: $\mathrm{Q}=-9201,61+4,6375 *$ jaar

groep 3: $\mathrm{Q}=-1305,44+20,82 *$ jaar

Grafiek 7: schatting van totaal aantal absolute beroepsziekten in de toekomst m.b.v. trendanalyse (1990 - 1993) 


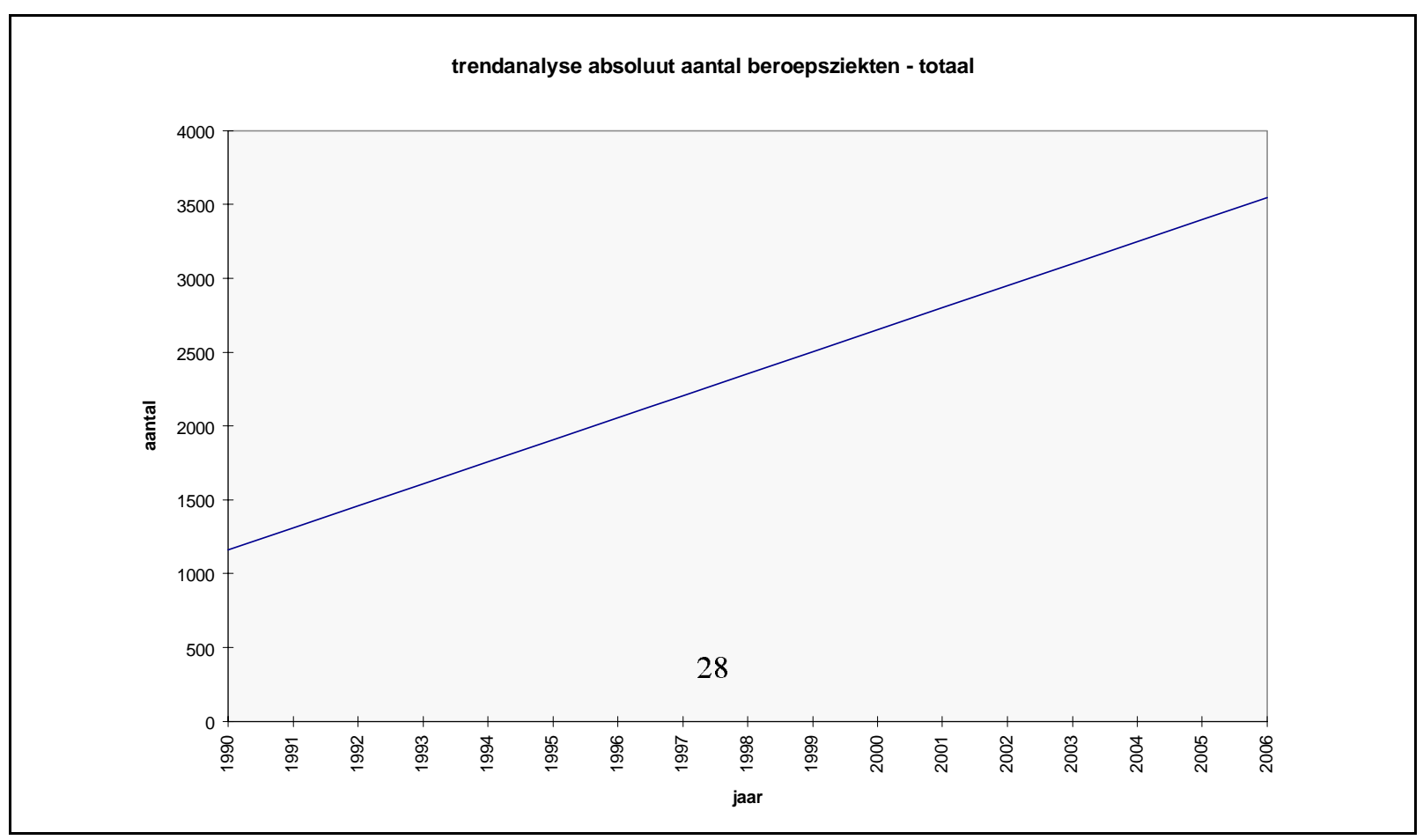


Grafiek 8: schatting van absoluut aantal beroepsziekten in de toekomst m.b.v. trendanalyse (1991 - 1993); alle groepen

groep $1: \mathrm{Q}=-92413+46 *$ jaar $\quad$ totaal $: \mathrm{Q}=62065+316,5 *$ jaar

groep $2: \mathrm{Q}=-16897+8,8 *$ jaar

groep $3: \mathrm{Q}=-3377,47+1,7 *$ jaar

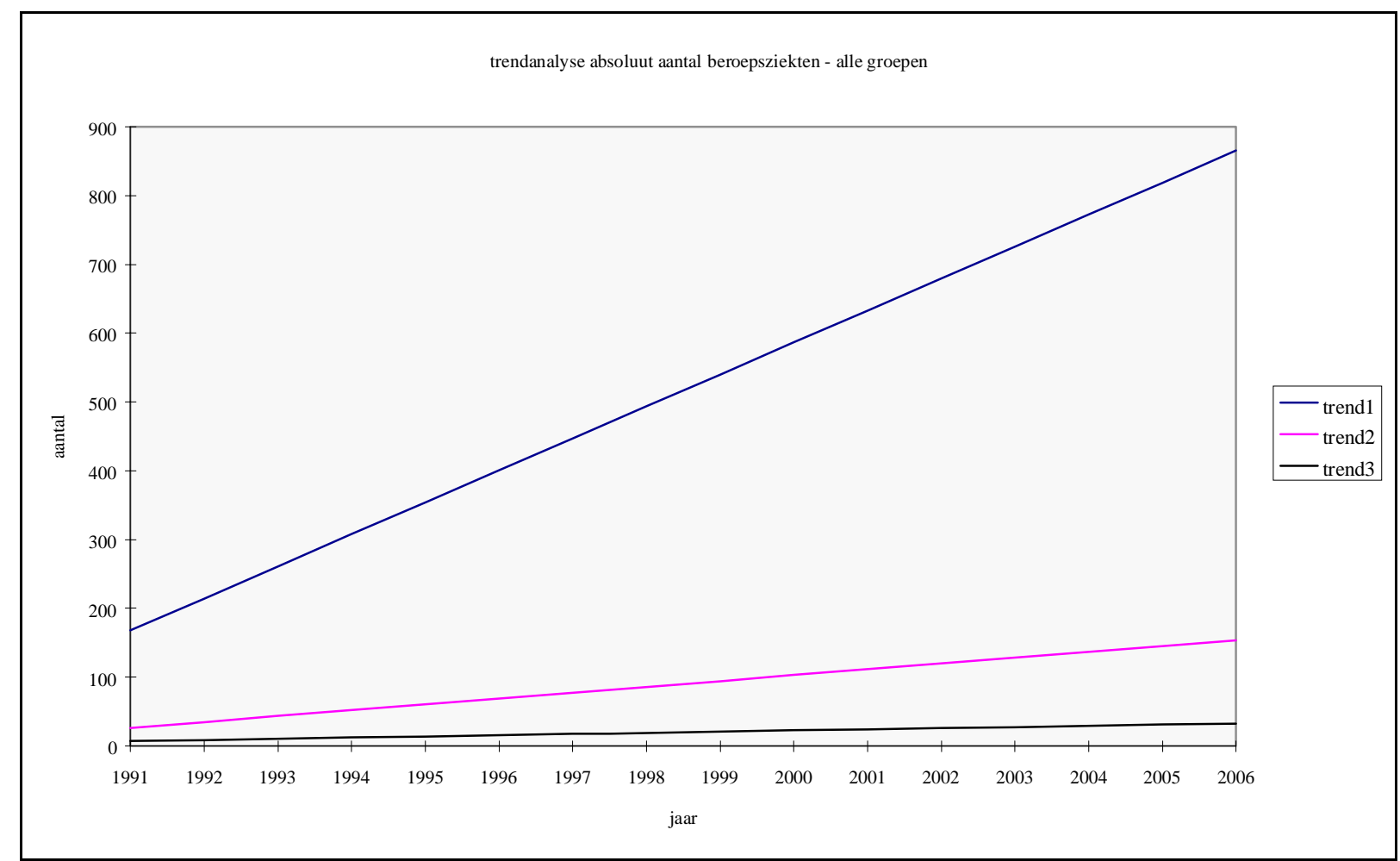

Grafiek 9: schatting van totaal aantal absolute beroepsziekten in de toekomst m.b.v. trendanalyse (1991 - 1993); totaal

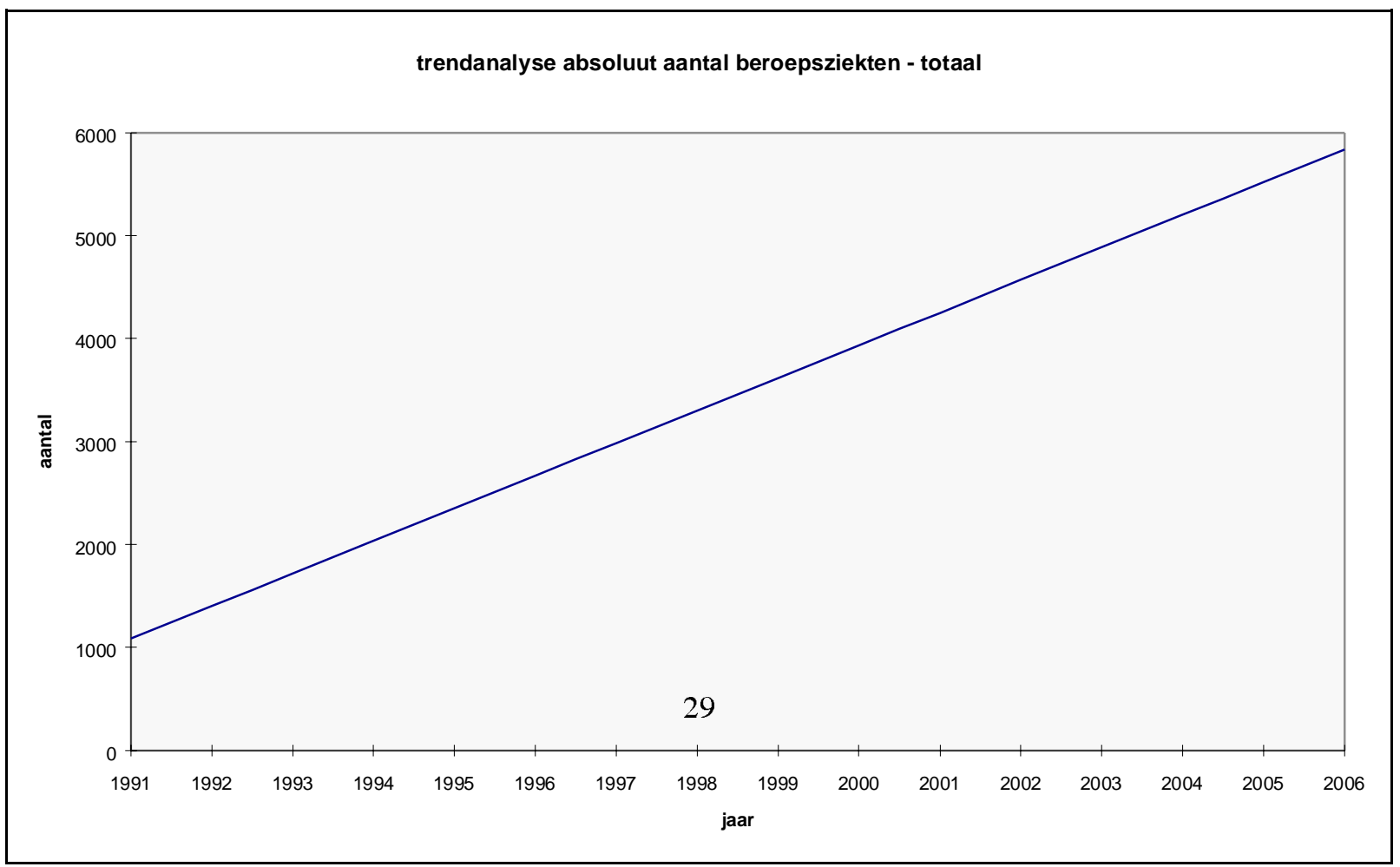




\section{deel 2}

analyse relatief aantal beroepsziekten 
groep 1: gemiddeld 64 tot 139 erkende beroepsziekten per jaar per 100.000 werknemers, die in de bedrijfstak werkzaam zijn.

groep 2: gemiddeld 17 tot 58 erkende beroepsziekten per jaar per 100.000 werknemers, die in de bedrijfstak werkzaam zijn.

groep 3: gemiddeld 3 tot 15 erkende beroepsziekten per jaar per 100.000 werknemers, die in de bedrijfstak werkzaam zijn.

\begin{tabular}{||l|l|l||}
\hline groep 1 & groep 2 & groep 3 \\
\hline $3,6,1,4,8$, & $7,13,18,12,10,11,5,2$, & $17,14,15,9,16$ \\
\hline
\end{tabular}

Tabel 2: bedrijfstakken ingedeeld naar relatief aantal erkende beroepsziekten per jaar; van 1990 tot en met 1993

\begin{tabular}{|r|r|r|r|r|r|r|}
\hline groep & bedrijfstak & $\mathbf{1 9 9 0}$ & $\mathbf{1 9 9 1}$ & $\mathbf{1 9 9 2}$ & $\mathbf{1 9 9 3}$ & gemiddelde \\
\hline 1 & 3 & 81 & 124 & 107 & 241 & 138,25 \\
\hline 1 & 6 & 74 & 73 & 88 & 143 & 94,50 \\
\hline 1 & 1 & 76 & 56 & 82 & 109 & 80,75 \\
\hline 1 & 4 & 53 & 41 & 61 & 104 & 64,75 \\
\hline 1 & 8 & 58 & 34 & 72 & 93 & 64,25 \\
\hline 2 & 7 & 56 & 36 & 56 & 83 & 57,75 \\
\hline 2 & 13 & 57 & 48 & 49 & 76 & 57,50 \\
\hline 2 & 18 & 55 & 52 & 62 & 45 & 53,50 \\
\hline 2 & 12 & 63 & 17 & 43 & 60 & 45,75 \\
\hline 2 & 10 & 42 & 25 & 40 & 40 & 36,75 \\
\hline 2 & 11 & 32 & 24 & 31 & 53 & 35,00 \\
\hline 2 & 5 & 23 & 20 & 28 & 34 & 26,25 \\
\hline 2 & 2 & 16 & 13 & 19 & 19 & 16,75 \\
\hline 3 & 17 & 16 & 13 & 11 & 20 & 15,00 \\
\hline 3 & 14 & 10 & 11 & 10 & 12 & 10,75 \\
\hline 3 & 15 & 8 & 4 & 6 & 8 & 6,50 \\
\hline 3 & 9 & 4 & 4 & 6 & 7 & 5,25 \\
\hline 3 & 16 & 2 & 3 & 4 & 4 & 3,25 \\
\hline & & & & & & $\mathbf{3 3 , 7 5}$ \\
\hline & & & $\mathbf{2 3}$ & $\mathbf{3 3}$ & $\mathbf{4 2}$ & \\
\hline
\end{tabular}

Grafiek 10: relatief aantal beroepsziekten - alle groepen 
Grafiek 11: relatief aantal beroepsziekten - groep 1
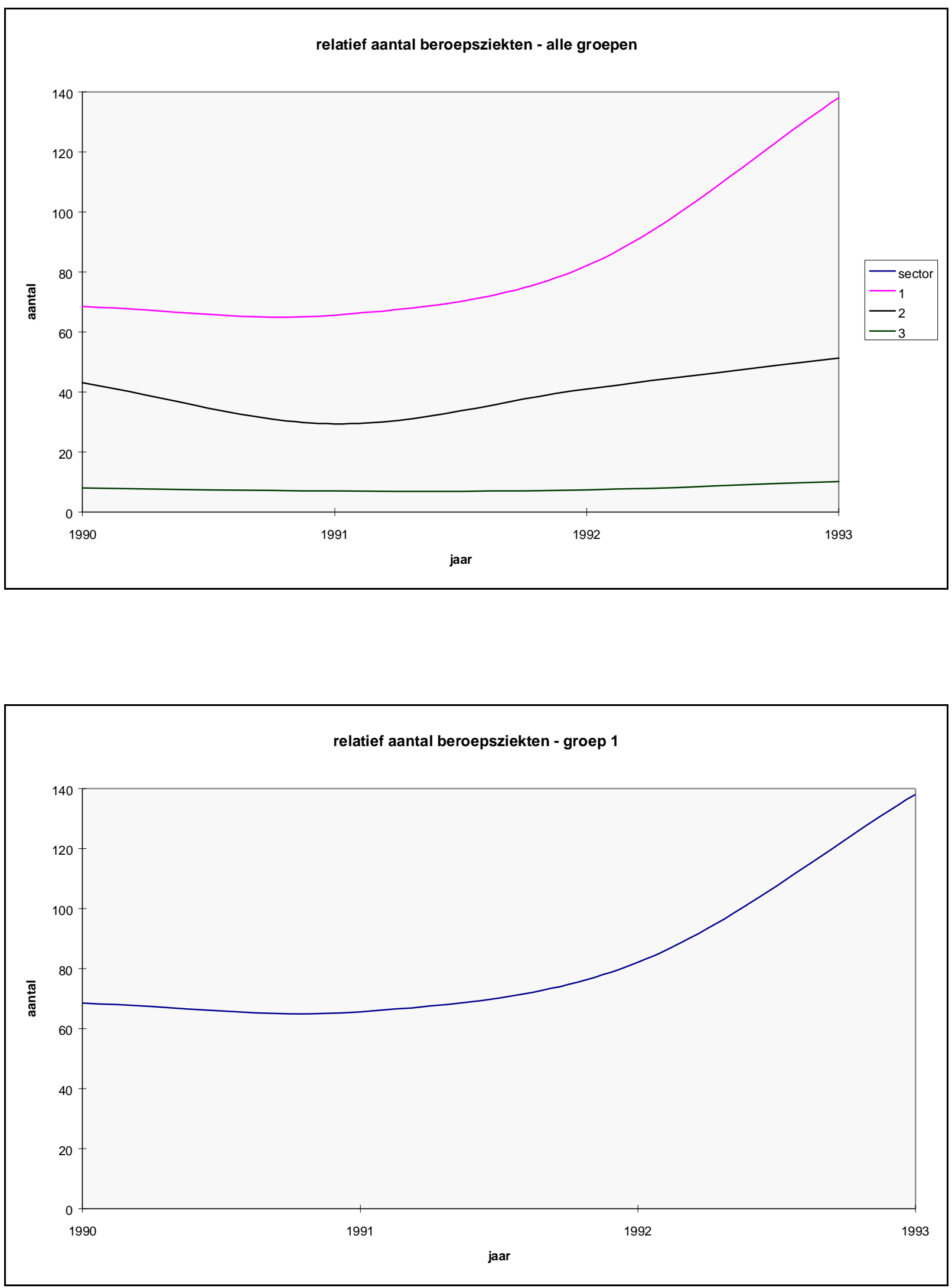


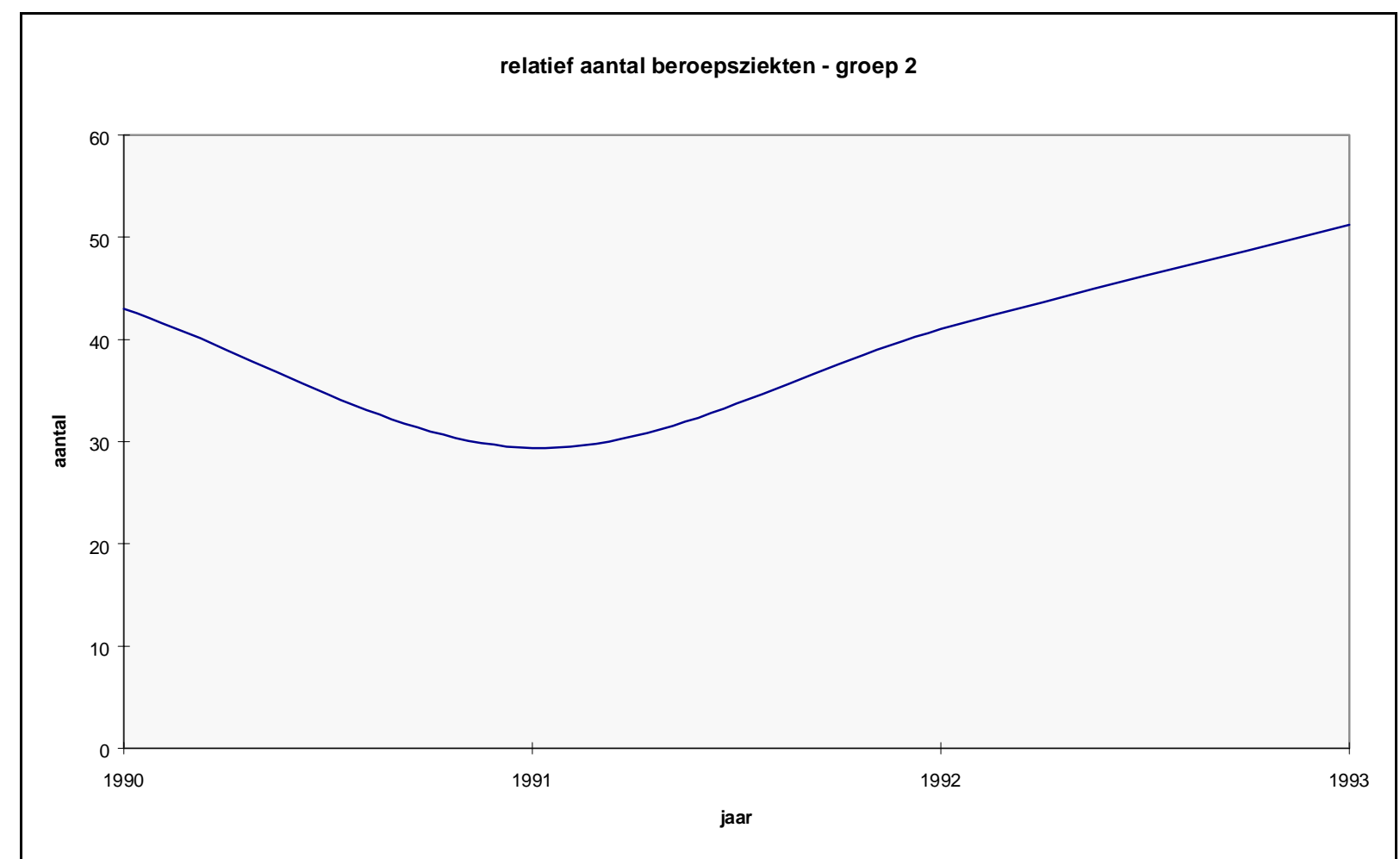

Grafiek 12: relatief aantal beroepsziekten - groep 2

Grafiek 13: relatief aantal beroepsziekten - groep 3 
Grafiek 14: relatief aantal beroepsziekten - totaal

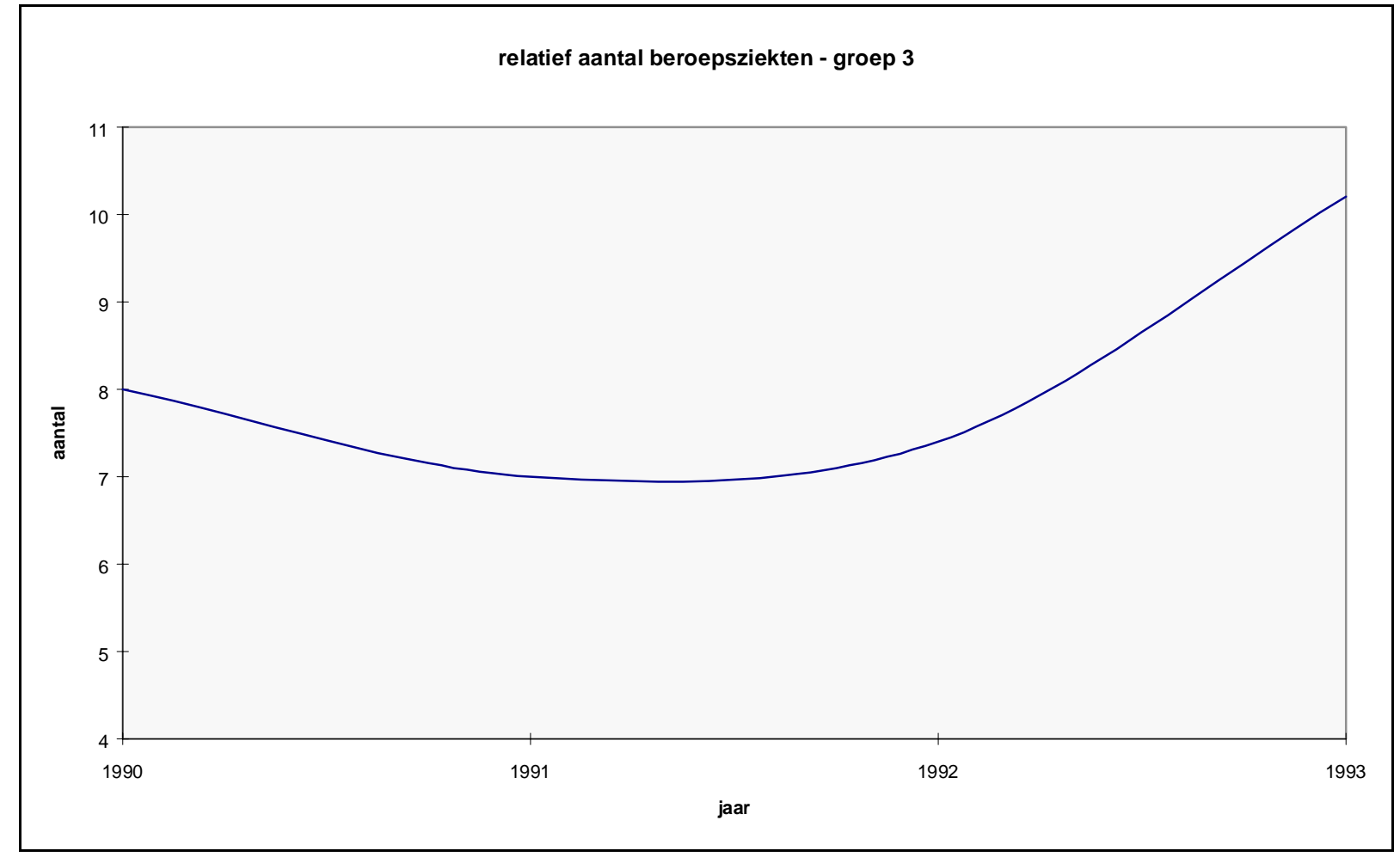




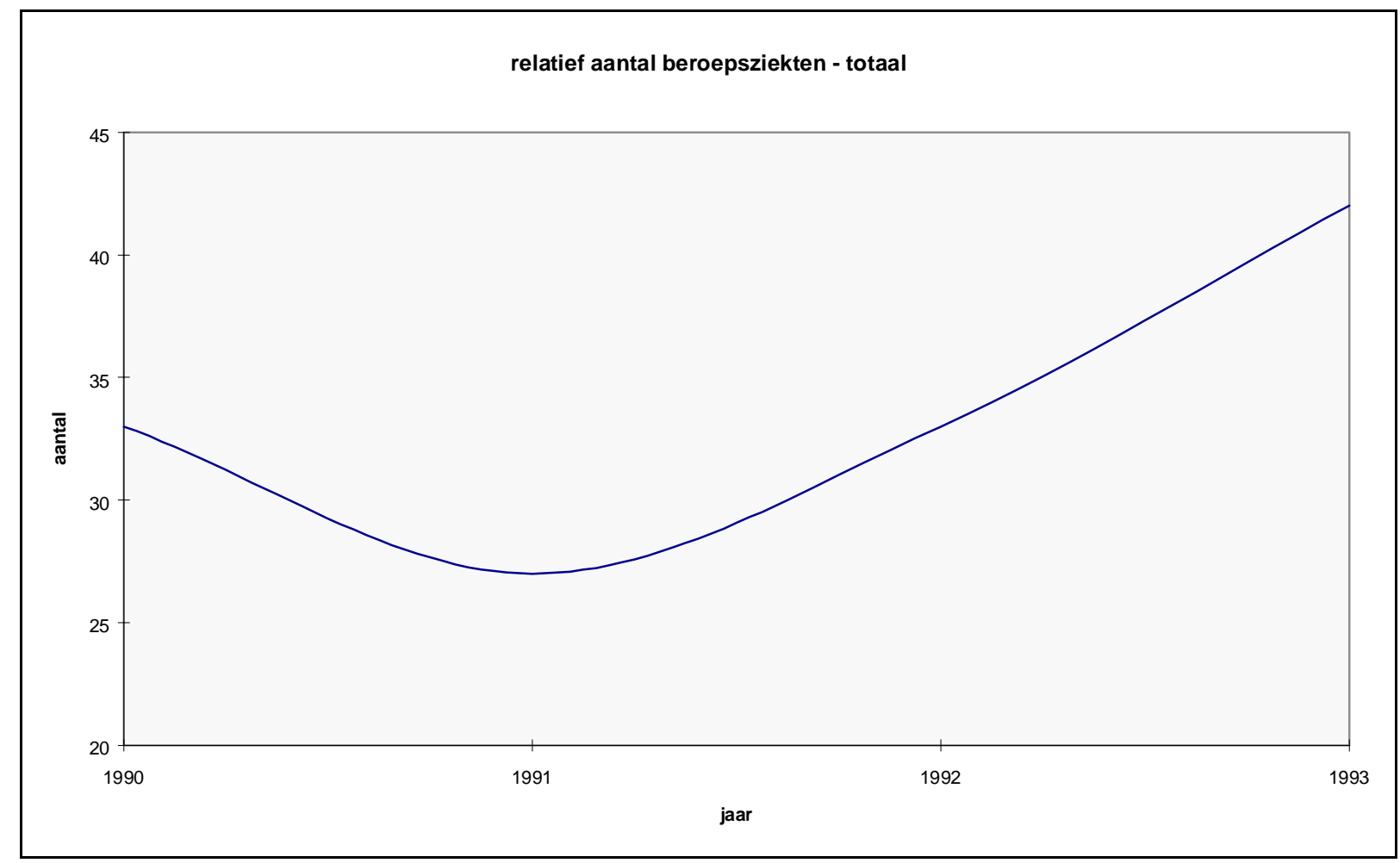




\section{TRENDANALYSE RELATIEF AANTAL BEROEPSZIEKTEN}

Grafiek 15: schatting van relatief aantal beroepsziekten (per 100.000 werknemers) m.b.v. trendanalyse (1990 - 1993); alle groepen groep 1: $\mathrm{Q}=-44760,1+22,52 *$ jaar totaal: $\mathrm{Q}=-6538,2+3,3 *$ jaar groep $2: \mathrm{Q}=-7202,925+3,6375 *$ jaar

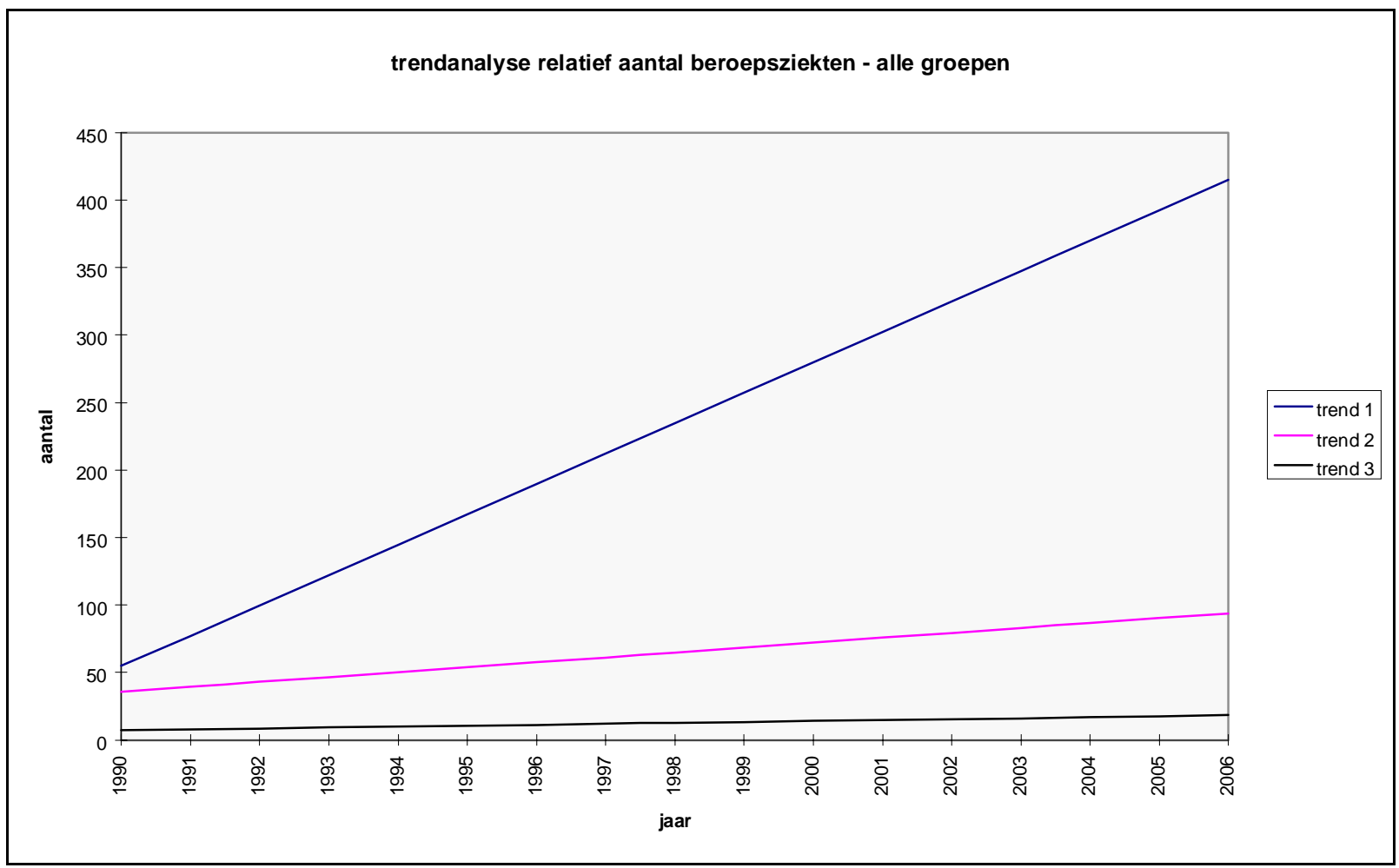

groep $3: \mathrm{Q}=-1385,9+0,7 *$ jaar

Grafiek 16: schatting relatief aantal beroepsziekten (per 100.000 werknemers) in de toekomst m.b.v. trendanalyse (1990 - 1993); totaal 


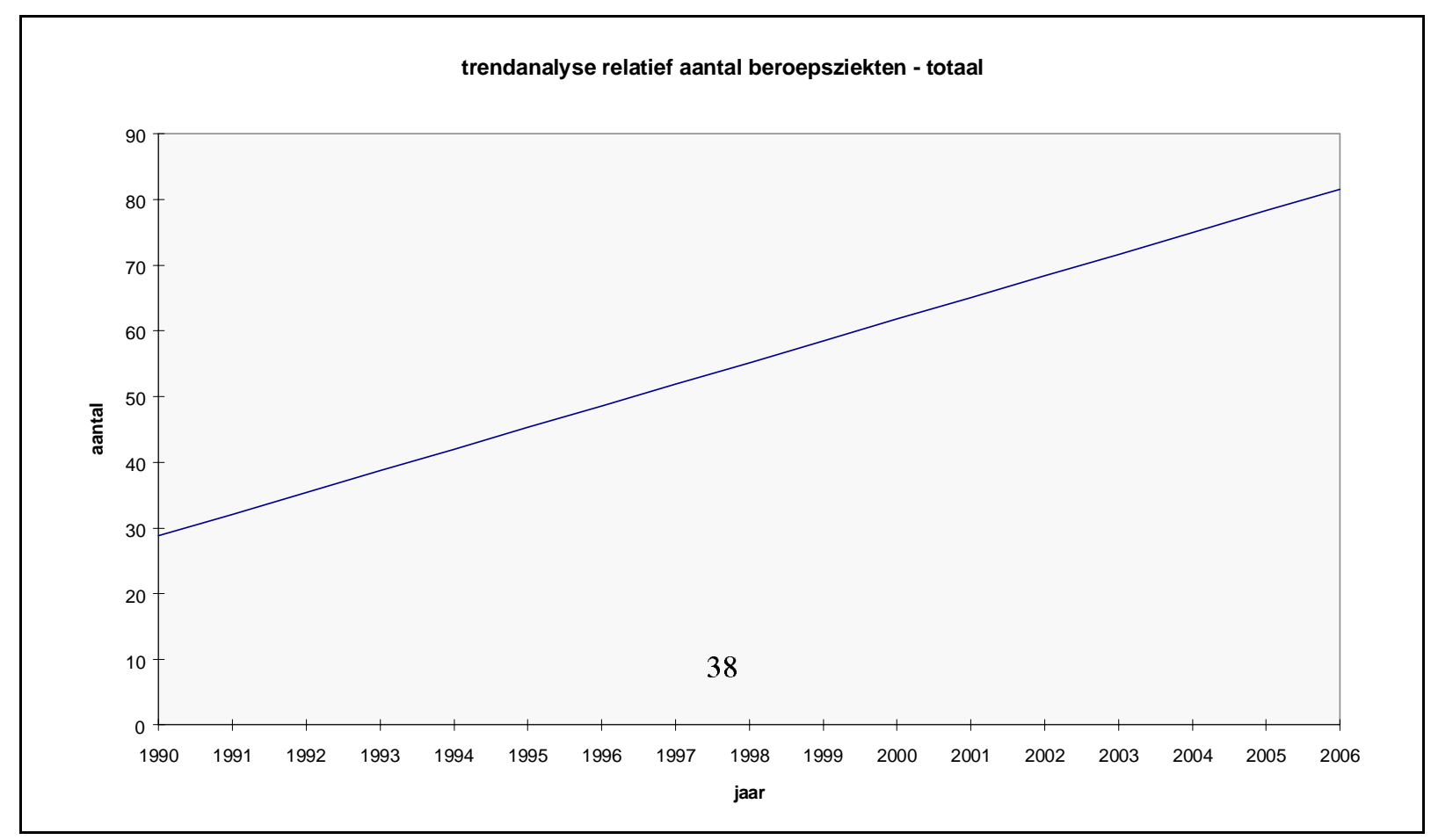


Grafiek 17: schatting relatief aantal beroepsziekten (per 100.000 werknemers) in de toekomst m.b.v. trendanalyse (1991 - 1993); alle groepen

groep 1: $Q=-72114,8+36,25 *$ jaar totaal : $\mathrm{Q}=-14906+7,5 *$ jaar

groep 2: $Q=-21747+10,938 *$ jaar

groep 3: $\mathrm{Q}=-3179+1,6 *$ jaar

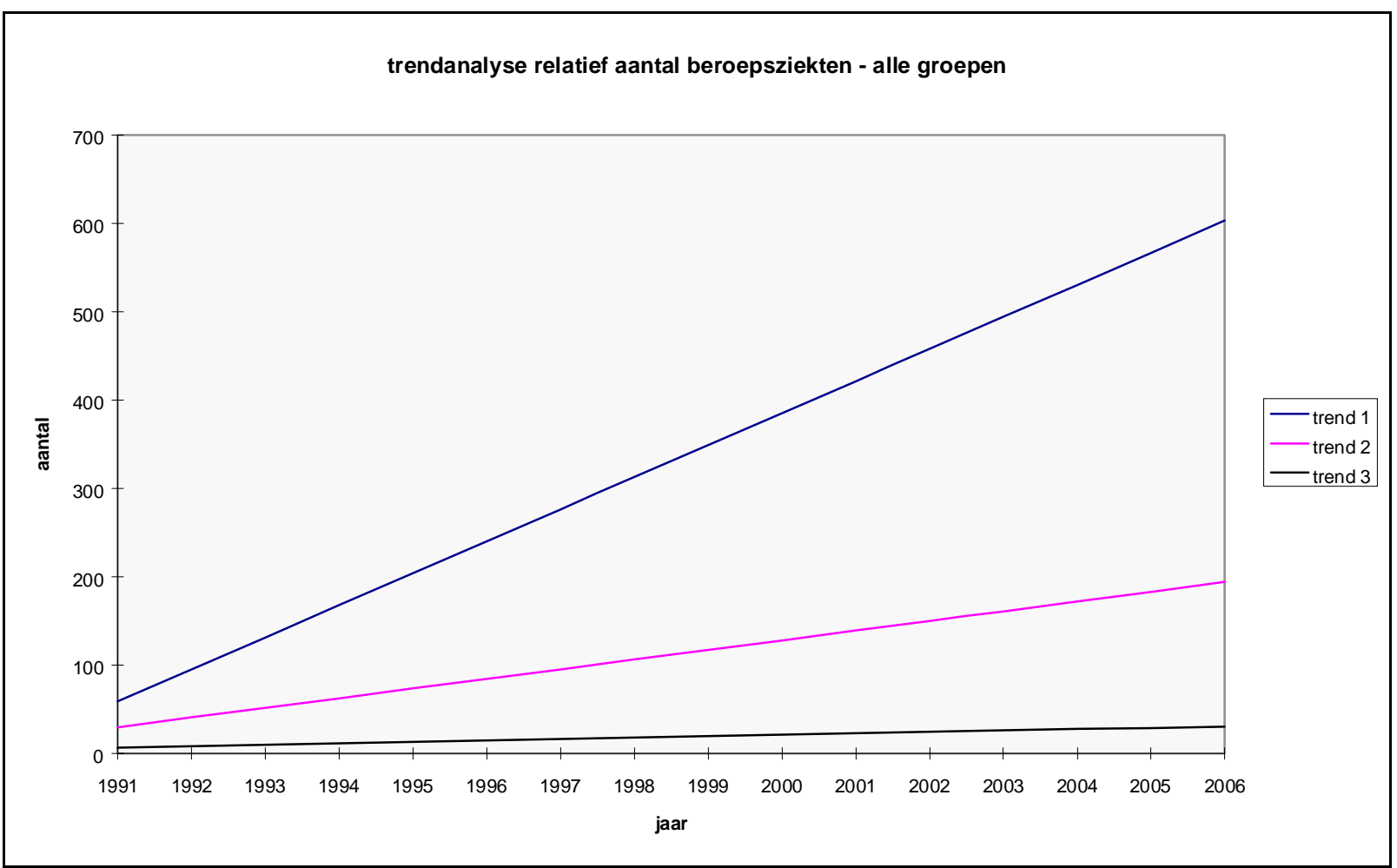

Grafiek 18: schatting relatief aantal beroepsziekten (per 100.000 werknemers) in de toekomst m.b.v. trendanalyse (1991 - 1993); totaal

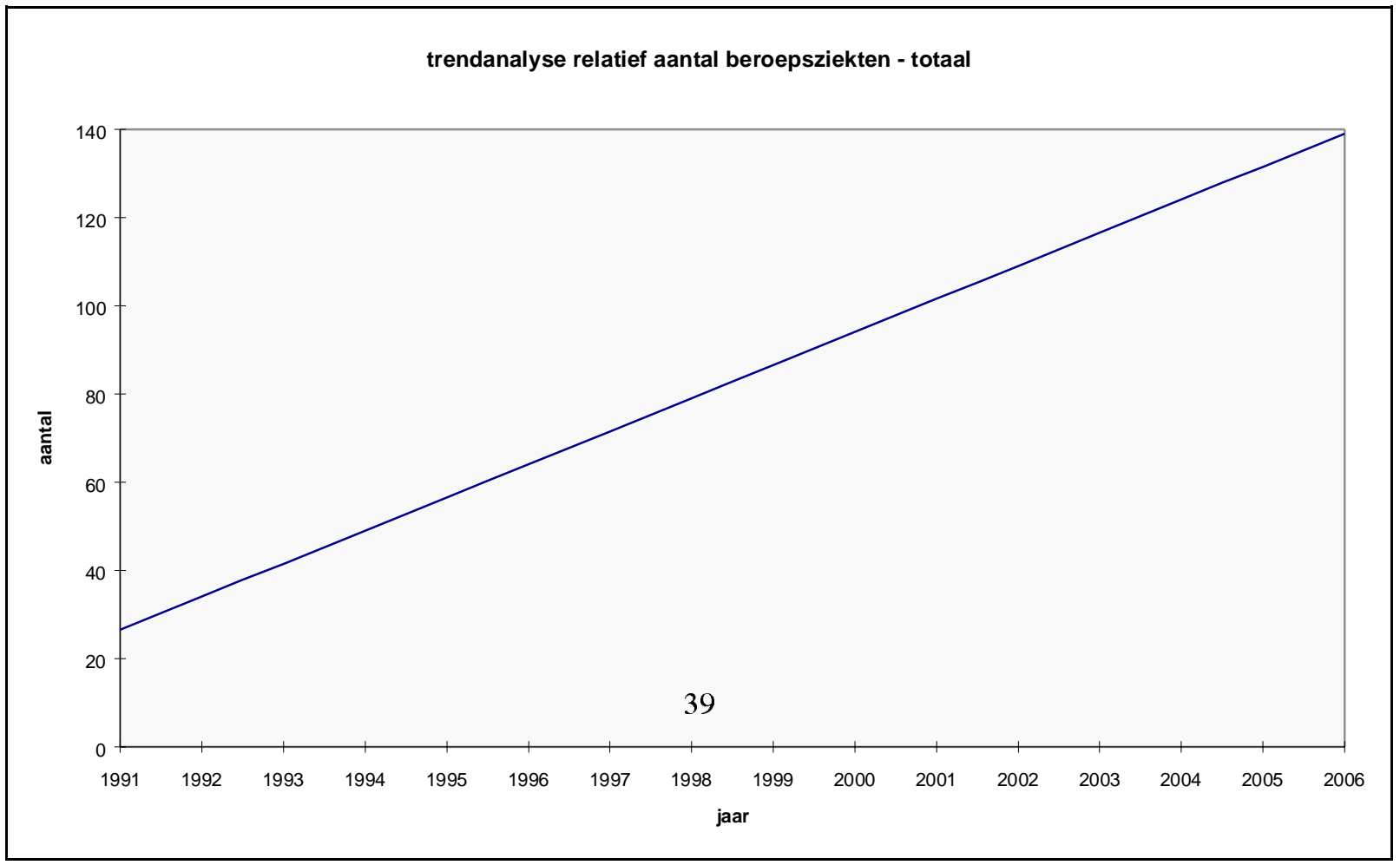


Tabel 3: aantal beroepsziekten - absoluut en relatief - per groep; van 1990 tot en met 1993

\begin{tabular}{||l|l|l|l|l||}
\hline & $\mathbf{1 9 9 0}$ & $\mathbf{1 9 9 1}$ & $\mathbf{1 9 9 2}$ & $\mathbf{1 9 9 3}$ \\
\hline groep 1 - abs. & 207,20 & 167,60 & 215,60 & 260,60 \\
\hline groep 1 - rel. & 68,40 & 65,60 & 82,00 & 138,00 \\
\hline groep 2 - abs. & 30,88 & 28,38 & 31,25 & 45,38 \\
\hline groep 2 - rel. & 43,00 & 29,38 & 41,00 & 51,25 \\
\hline groep 3 - abs. & 9,00 & 6,60 & 10,20 & 10.00 \\
\hline groep 3 - rel. & 8.00 & 7,00 & 7,40 & 10,20 \\
\hline
\end{tabular}




\section{deel 3}

\section{analyse absoluut aantal arbeidsongevallen}


groep 1: gemiddeld 297 tot 999 arbeidsongevallen per jaar, van het totaal aantal werknemers in de bedrijfstak

groep 2: gemiddeld 68 tot 290 arbeidsongevallen per jaar, van het totaal aantal werknemers per bedrijfstak

groep 3: gemiddeld 7 tot 65 arbeidsongevallen per jaar, van het totaal aantal werknemers in een bedrijfstak

\begin{tabular}{||l|l|l||}
\hline groep 1 & groep 2 & groep 3 \\
\hline $13,17,14,4,12$ & $15,18,16,6,7,5,9,3$ & $8,1,2,11,10$ \\
\hline
\end{tabular}

Tabel 4: bedrijfstakken ingedeeld naar absoluut aantal arbeidsongevallen per jaar; van 1990 tot en met 1993

\begin{tabular}{|r|r|r|r|r|r|r|}
\hline bedrijfstak & groep & $\mathbf{1 9 9 0}$ & $\mathbf{1 9 9 1}$ & $\mathbf{1 9 9 2}$ & $\mathbf{1 9 9 3}$ & gemiddelde \\
\hline 13 & 1 & 1225 & 909 & 886 & 975 & 998,75 \\
\hline 17 & 1 & 725 & 650 & 721 & 797 & 723,25 \\
\hline 14 & 1 & 487 & 468 & 512 & 528 & 498,75 \\
\hline 4 & 1 & 489 & 409 & 485 & 535 & 479,50 \\
\hline 12 & 1 & 311 & 278 & 288 & 314 & 297,75 \\
\hline 15 & 2 & 332 & 254 & 278 & 296 & 290,00 \\
\hline 18 & 2 & 256 & 231 & 245 & 273 & 251,25 \\
\hline 16 & 2 & 194 & 206 & 188 & 239 & 206,75 \\
\hline 6 & 2 & 150 & 133 & 139 & 167 & 147,25 \\
\hline 7 & 2 & 100 & 90 & 94 & 99 & 95,75 \\
\hline 5 & 2 & 91 & 76 & 88 & 98 & 88,25 \\
\hline 9 & 2 & 84 & 80 & 94 & 95 & 88,25 \\
\hline 3 & 2 & 71 & 74 & 64 & 66 & 68,75 \\
\hline 8 & 3 & 67 & 56 & 56 & 78 & 64,25 \\
\hline 1 & 3 & 67 & 50 & 61 & 64 & 60,50 \\
\hline 2 & 3 & 49 & 28 & 25 & 30 & 33,00 \\
\hline 11 & 3 & 32 & 28 & 31 & 29 & 30,00 \\
\hline 10 & 3 & 9 & 7 & 7 & 8 & 7,75 \\
\hline totaal & & $\mathbf{4 7 3 8}$ & $\mathbf{4 0 2 6}$ & $\mathbf{4 2 6 4}$ & $\mathbf{4 6 9 3}$ & \\
\hline
\end{tabular}


Grafiek 19: absoluut aantal arbeidsongevallen - alle groepen

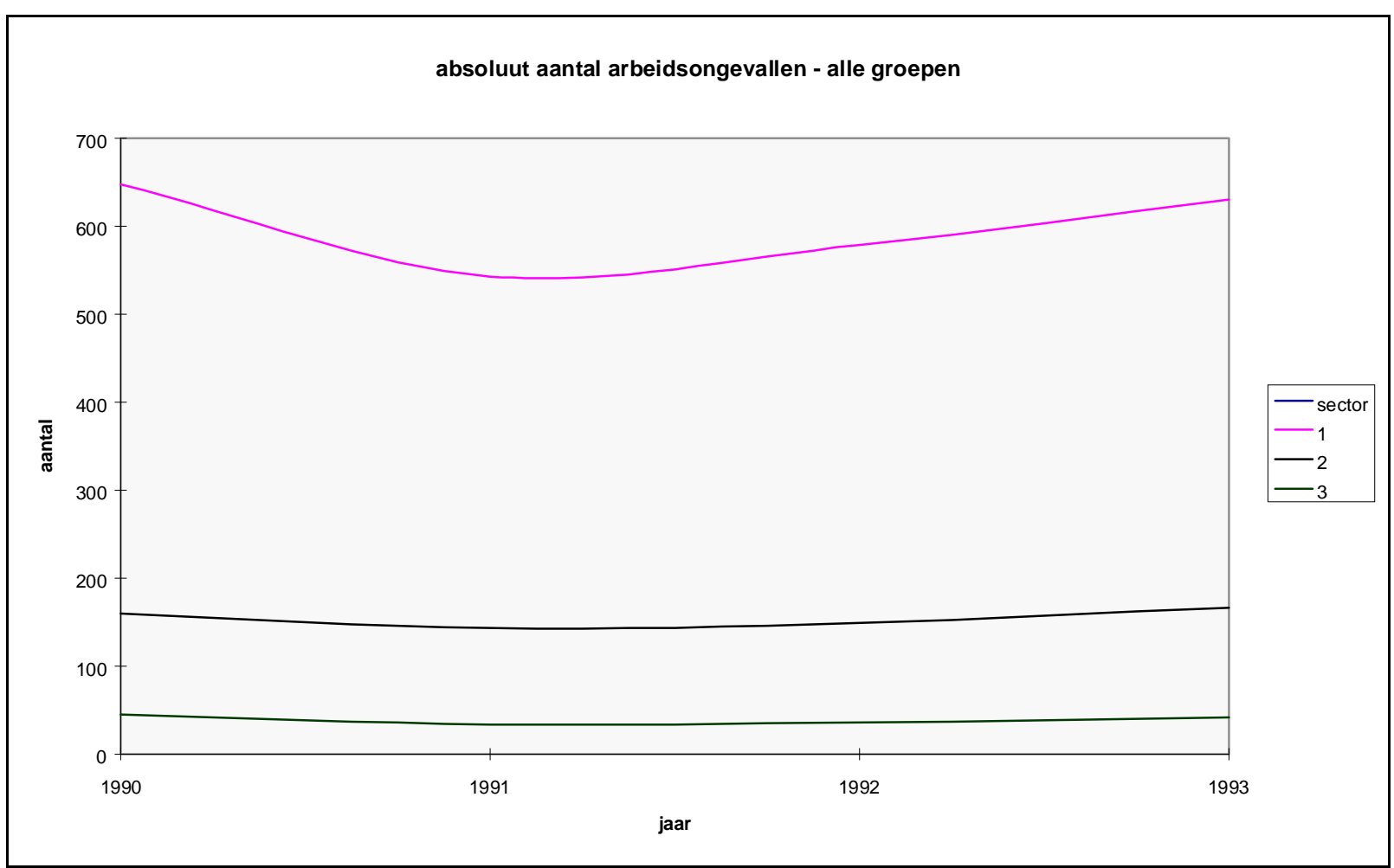

Grafiek 20: absoluut aantal arbeidsongevallen - groep 1

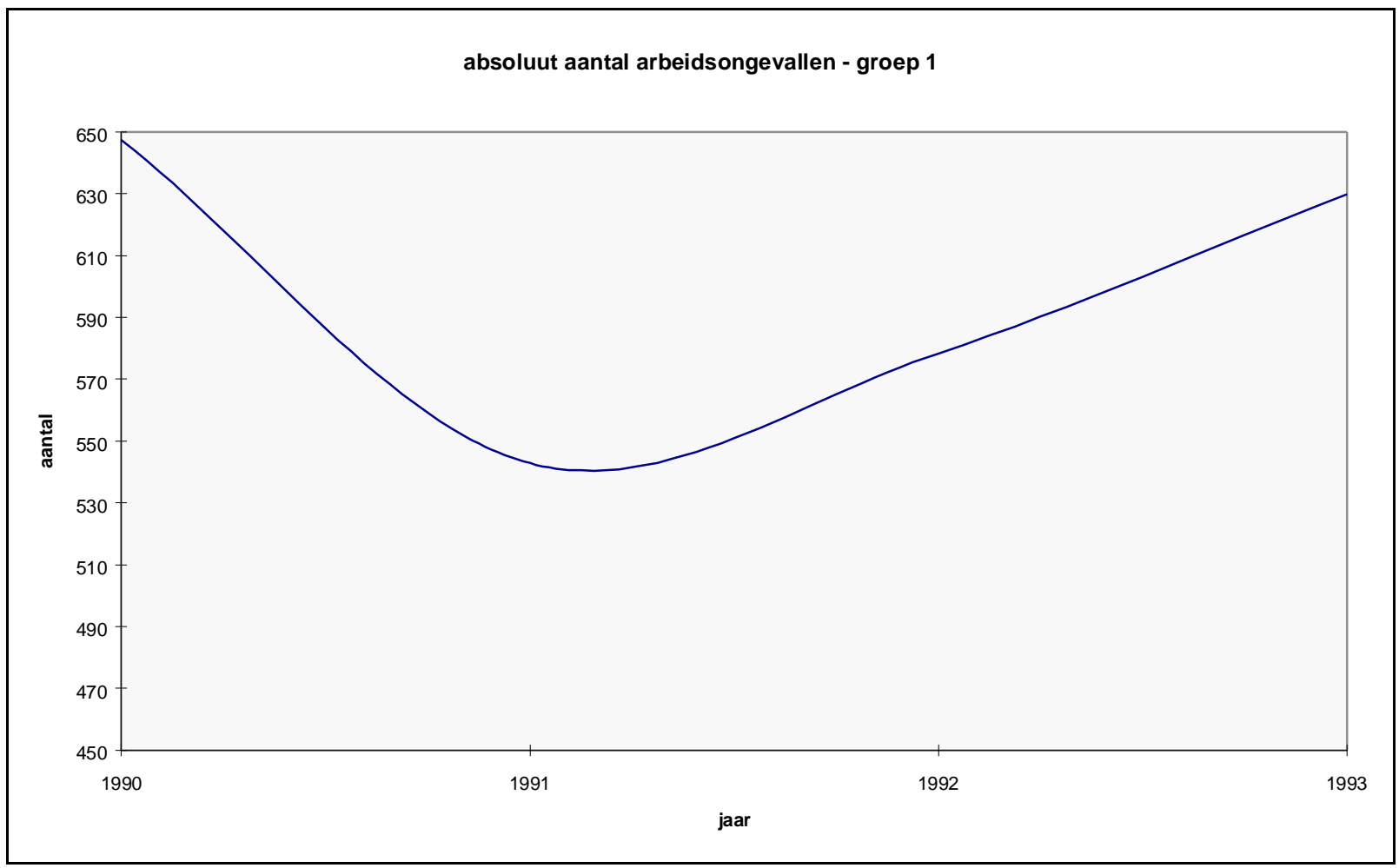




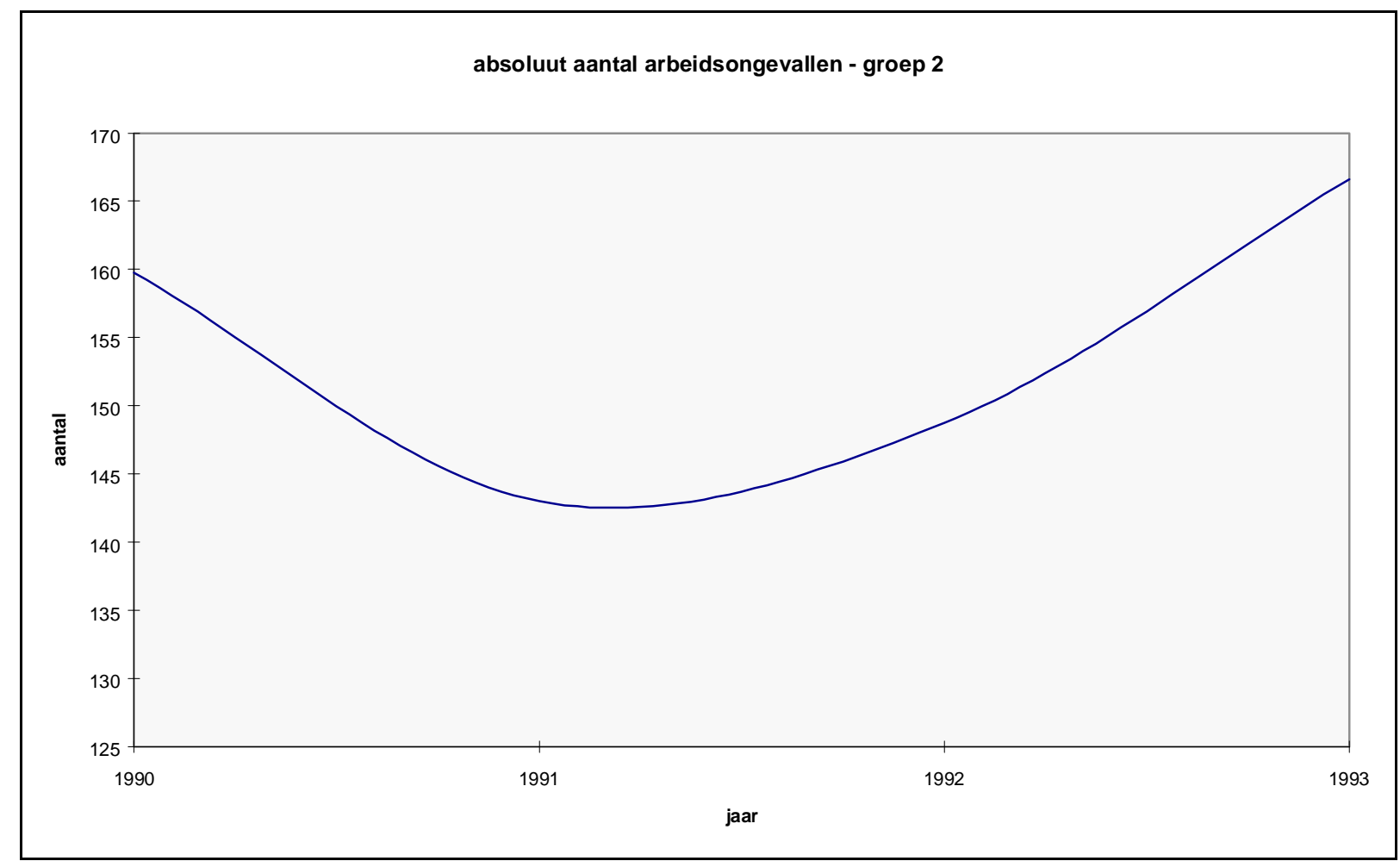

Grafiek 21: absoluut aantal arbeidsongevallen - groep 2

Grafiek 22: absoluut aantal arbeidsongevallen - groep 3 
Grafiek 23: absoluut aantal arbeidsongevallen - totaal

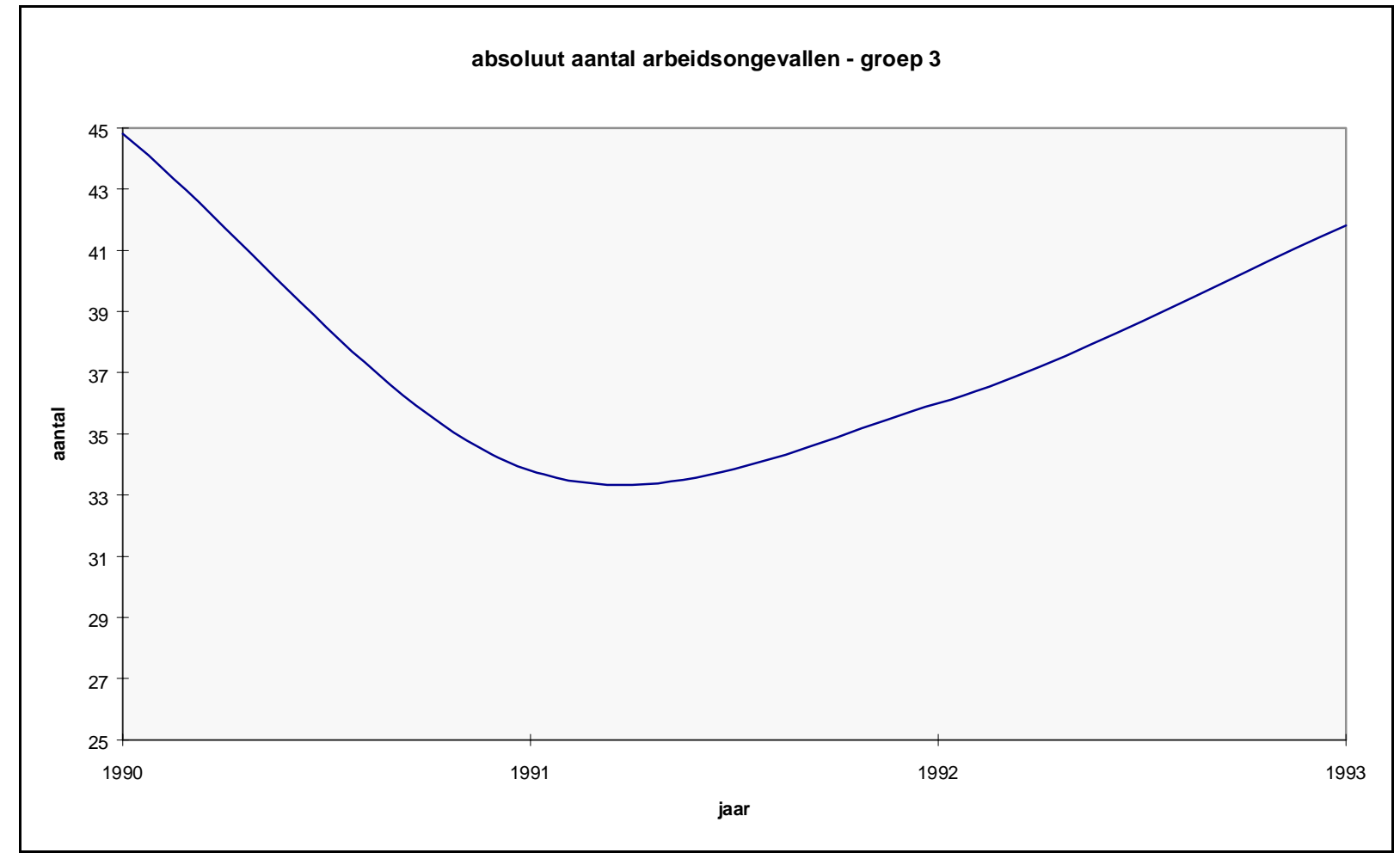




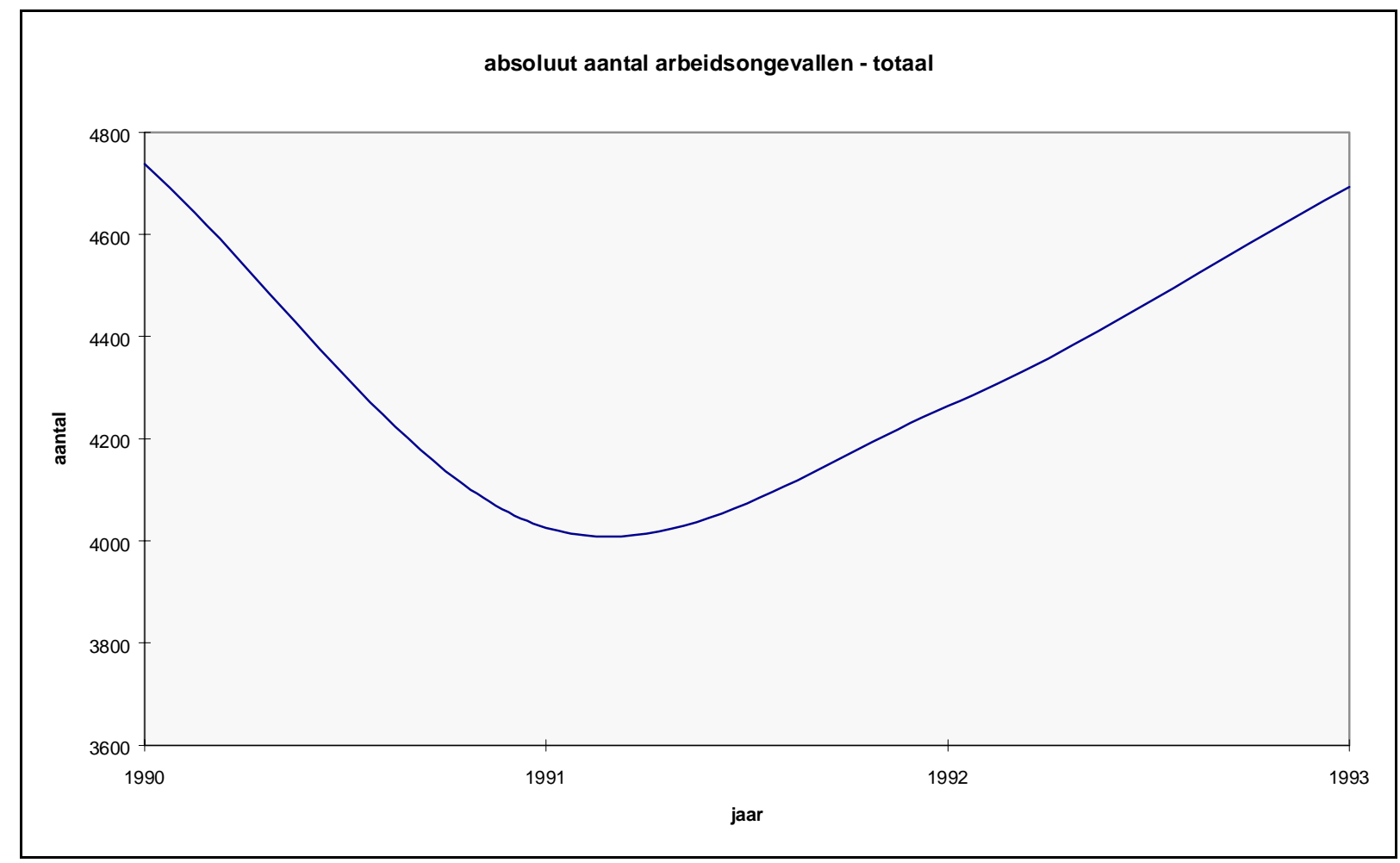




\section{TRENDANALYSE ABSOLUUT AANTAL ARBEIDSONGEVALLEN}

Grafiek 24: schatting van absoluut aantal arbeidsongevallen in de toekomst m.b.v. trendanalyse (1990 - 1993); alle groepen

groep 1: $Q=4024,98-1,72 *$ jaar totaal $: Q=-16082,2+10,3 *$ jaar

groep $2: Q=-5098,05+2,64 *$ jaar

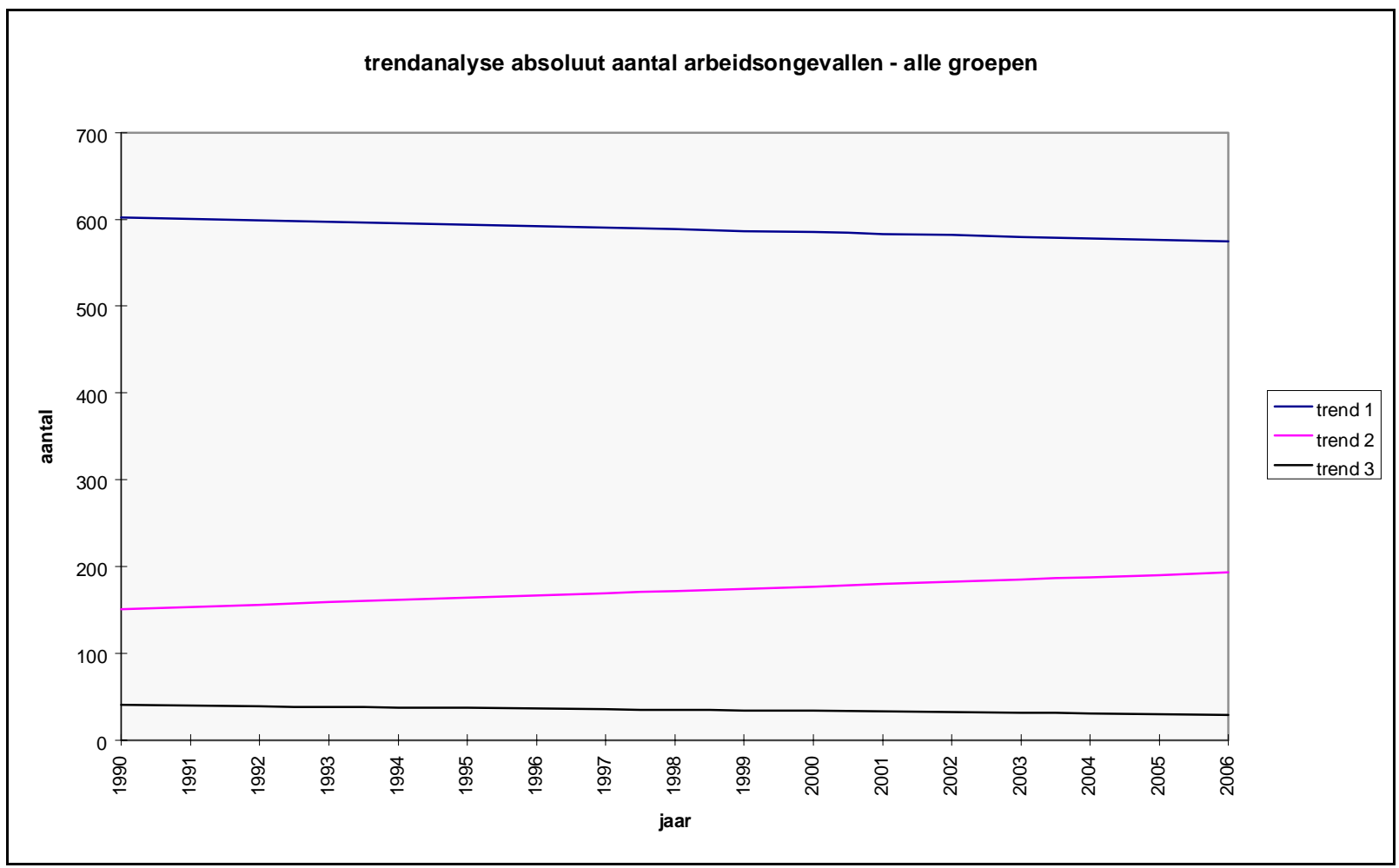

groep $3: \mathrm{Q}=1393,32-0,68 *$ jaar

Grafiek 25: schatting absoluut aantal arbeidsongevallen in de toekomst m.b.v. trendanalyse (1990 - 1993); totaal 
Grafiek 26: schatting absoluut aantal arbeidsongevallen in de toekomst m.b.v. trendanalyse (1991 - 1993); alle groepen

groep 1: $\mathrm{Q}=-86068,33+43,5 *$ jaar

totaal $: Q=-660004,33+333,5 *$ jaar groep $2: \mathrm{Q}=-23377,71+11,81 *$ jaar

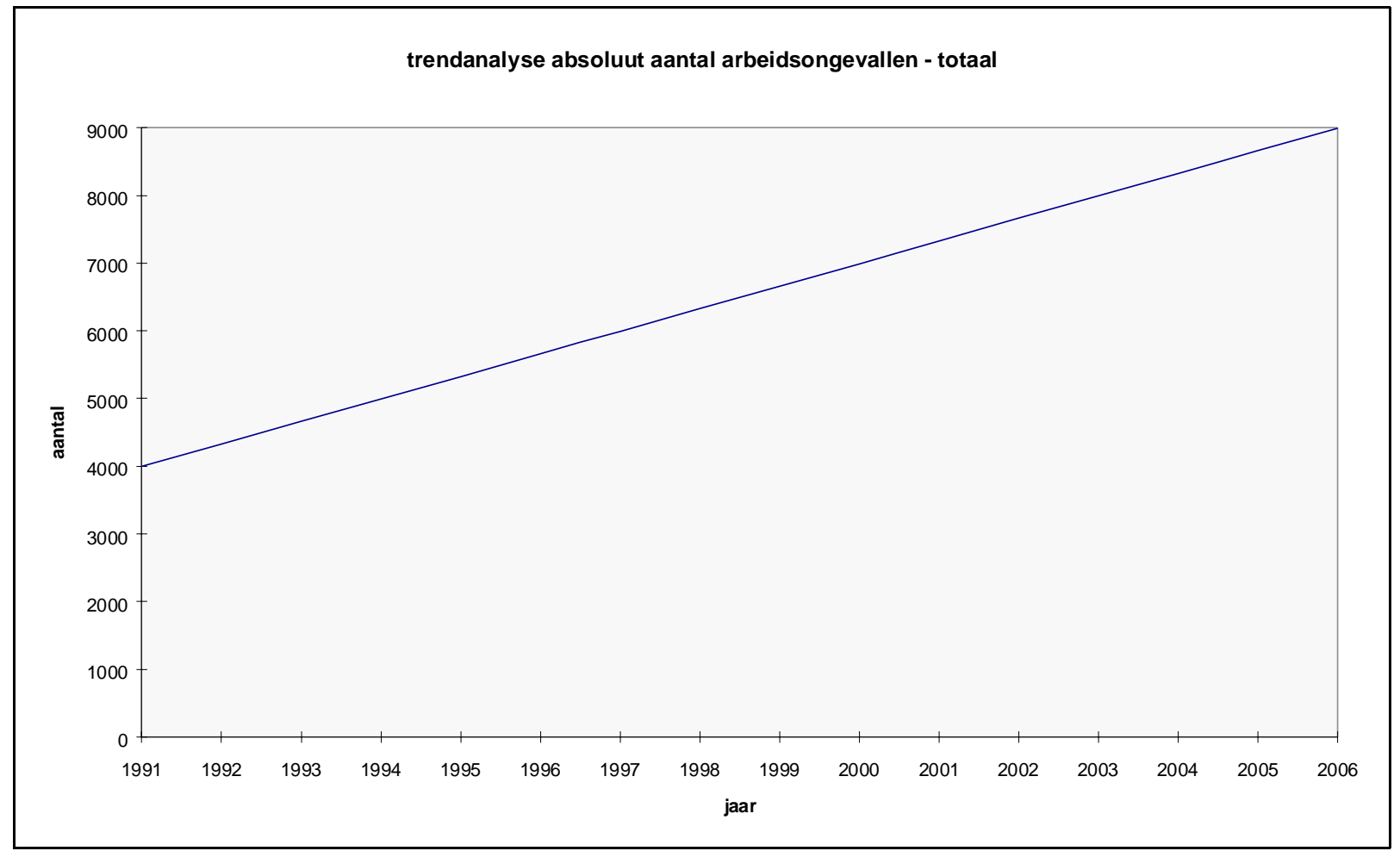

groep $3: \mathrm{Q}=-7930,8+4 *$ jaar

Grafiek 27: schatting absoluut aantal arbeidsongevallen in de toekomst m.b.v. trendanalyse (1991 - 1993); totaal

trendanalyse absoluut aantal arbeidsongevallen - totaal

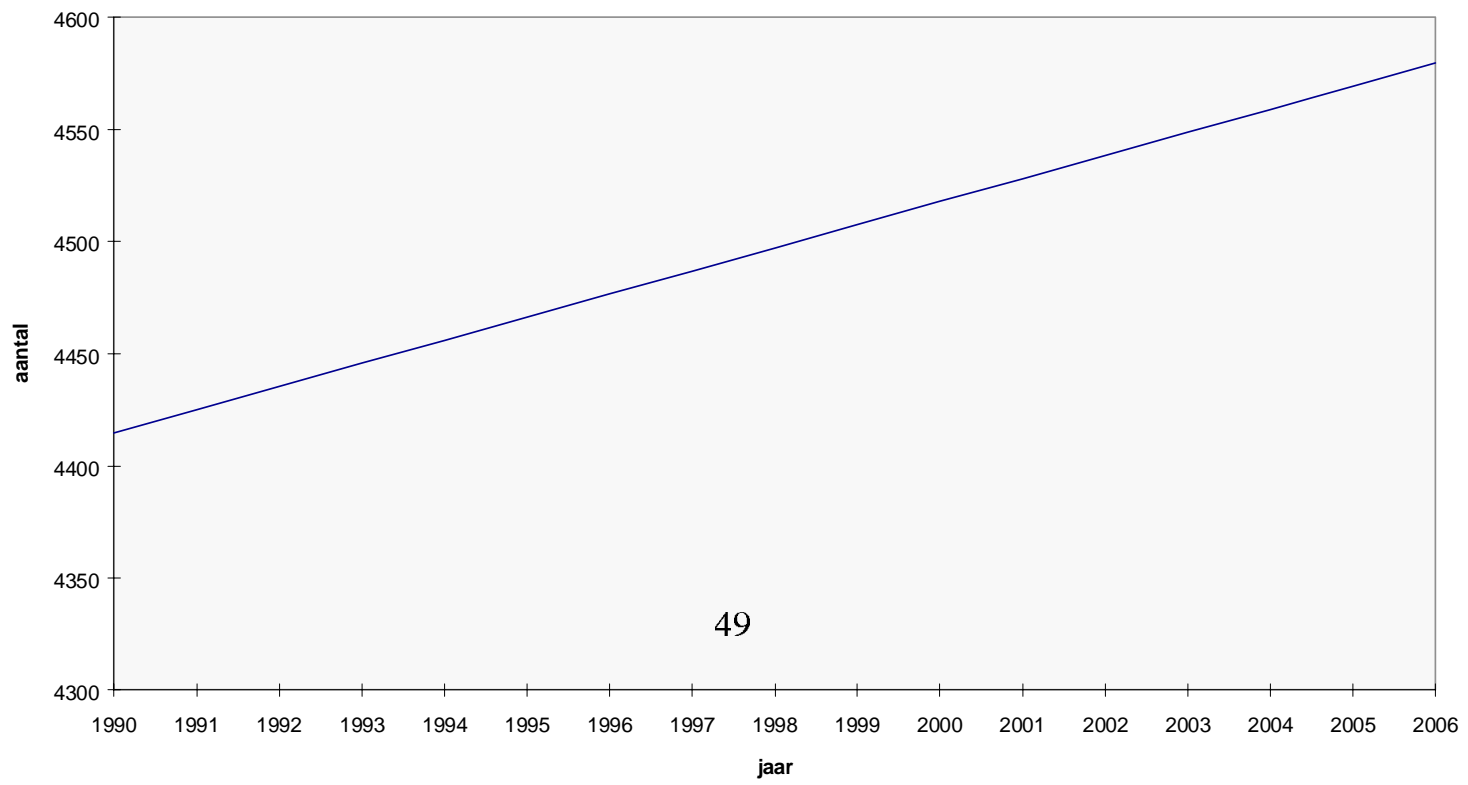




\section{deel 4}

\section{relatief aantal arbeidsongevallen}

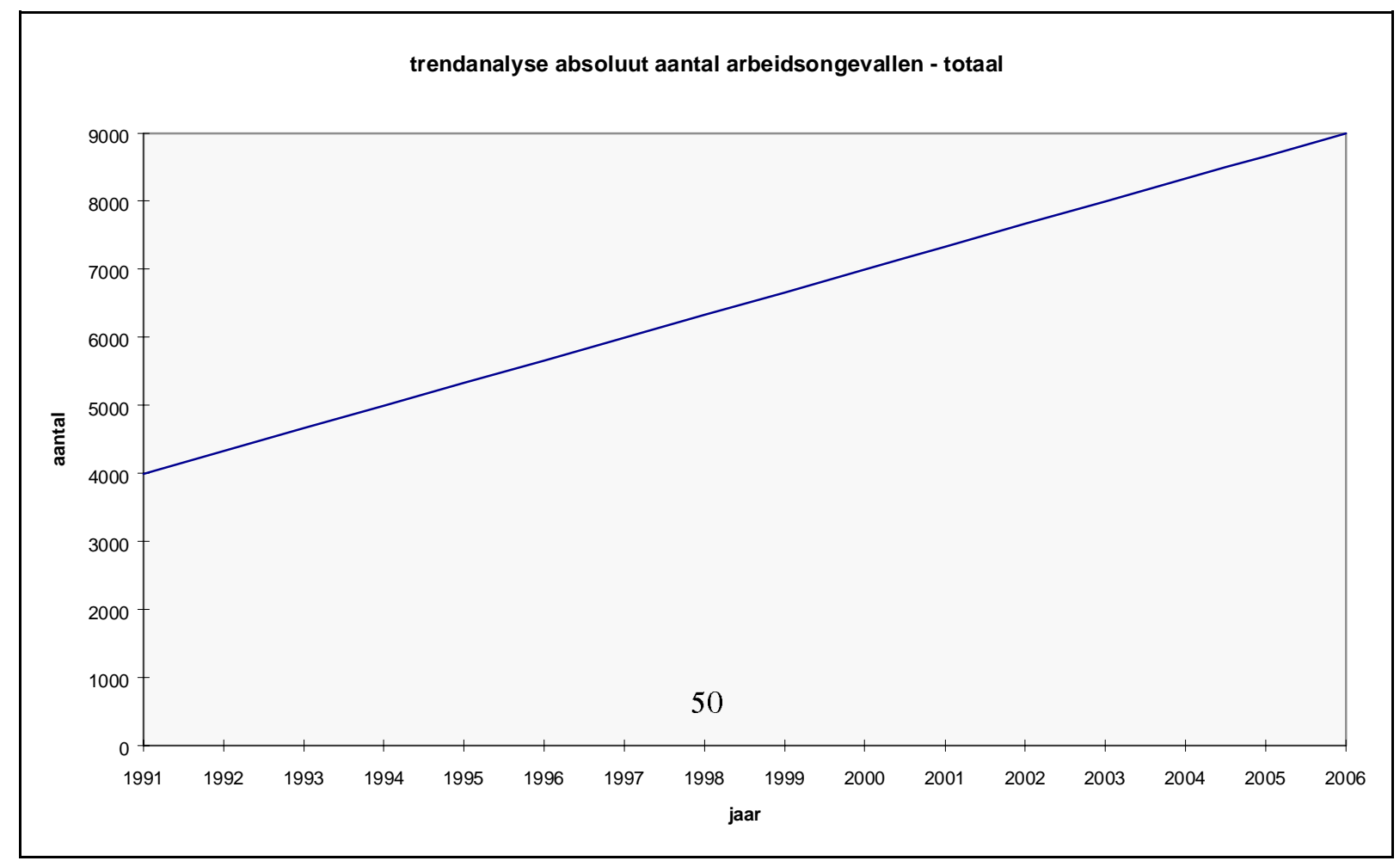


groep 1: gemiddeld 194 tot 276 arbeidsongevallen per jaar per 100.000 werknemers in de bedrijfstak

groep 2: gemiddeld 73 tot 170 arbeidsongevallen per jaar per 100.000 werknemers in de bedrijfstak

groep 3: gemiddeld 35 tot 70 arbeidsongevallen per jaar per 100.000 werknemers in de bedrijfstak

\begin{tabular}{|l|l|l||}
\hline groep 1 & groep 2 & groep 3 \\
\hline $13,3,8,7,17$ & $1,4,14,10,6,12,11,2$ & $5,9,15,16,18$ \\
\hline
\end{tabular}

Tabel 5: bedrijfstakken ingedeeld naar het relatieve aantal arbeidsongevallen per jaar; van 1990 tot en met 1993

\begin{tabular}{|r|r|r|r|r|r|r|}
\hline bedrijfstak & \multicolumn{1}{|c|}{ groep } & $\mathbf{1 9 9 0}$ & $\mathbf{1 9 9 1}$ & $\mathbf{1 9 9 2}$ & $\mathbf{1 9 9 3}$ & gemiddelde \\
\hline 13 & 1 & 334 & 246 & 245 & 276 & 275,25 \\
\hline 3 & 1 & 238 & 245 & 221 & 244 & 237,00 \\
\hline 8 & 1 & 240 & 193 & 201 & 300 & 233,50 \\
\hline 7 & 1 & 233 & 204 & 214 & 230 & 220,25 \\
\hline 17 & 1 & 201 & 175 & 189 & 211 & 194,00 \\
\hline 1 & 2 & 186 & 139 & 169 & 183 & 169,25 \\
\hline 4 & 2 & 154 & 127 & 150 & 174 & 151,25 \\
\hline 14 & 2 & 139 & 127 & 137 & 143 & 136,50 \\
\hline 10 & 2 & 125 & 106 & 115 & 128 & 118,50 \\
\hline 6 & 2 & 105 & 92 & 99 & 123 & 104,75 \\
\hline 12 & 2 & 111 & 96 & 99 & 101 & 101,75 \\
\hline
\end{tabular}




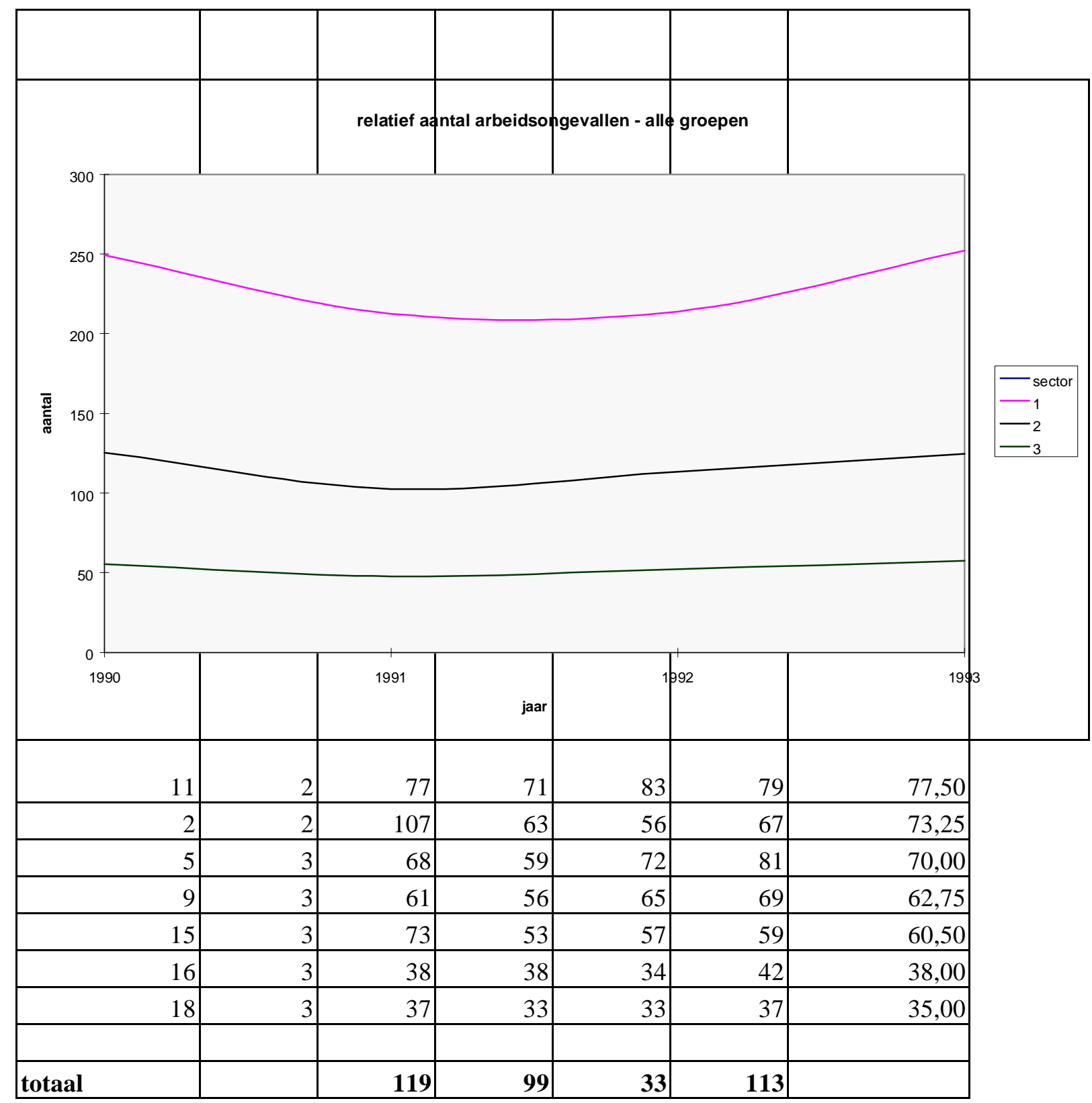

Grafiek 28: relatief aantal arbeidsongevallen - alle groepen

Grafiek 29: relatief aantal arbeidsongevallen - groep 1 
Grafiek 30: relatief aantal arbeidsongevallen - groep 2

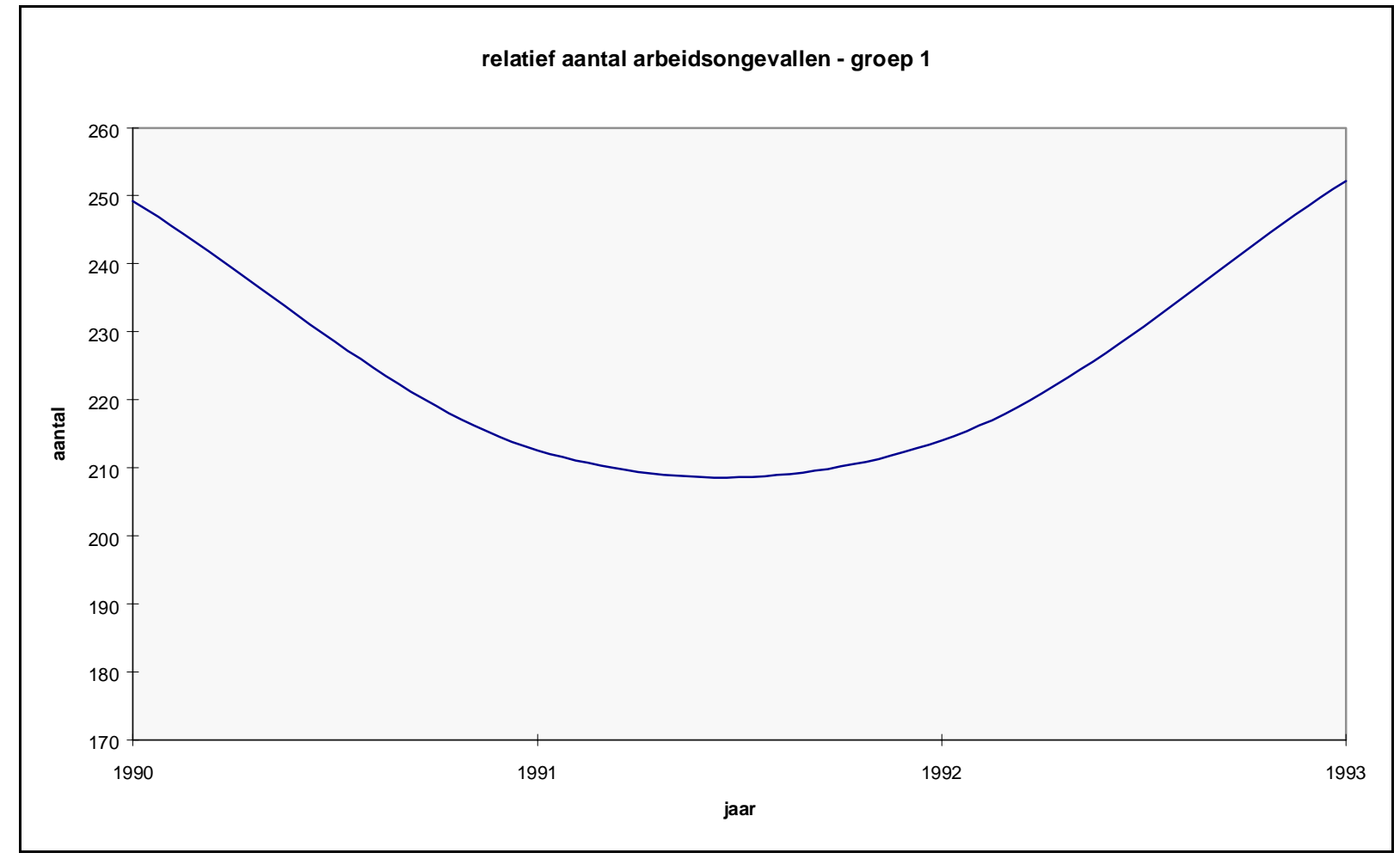




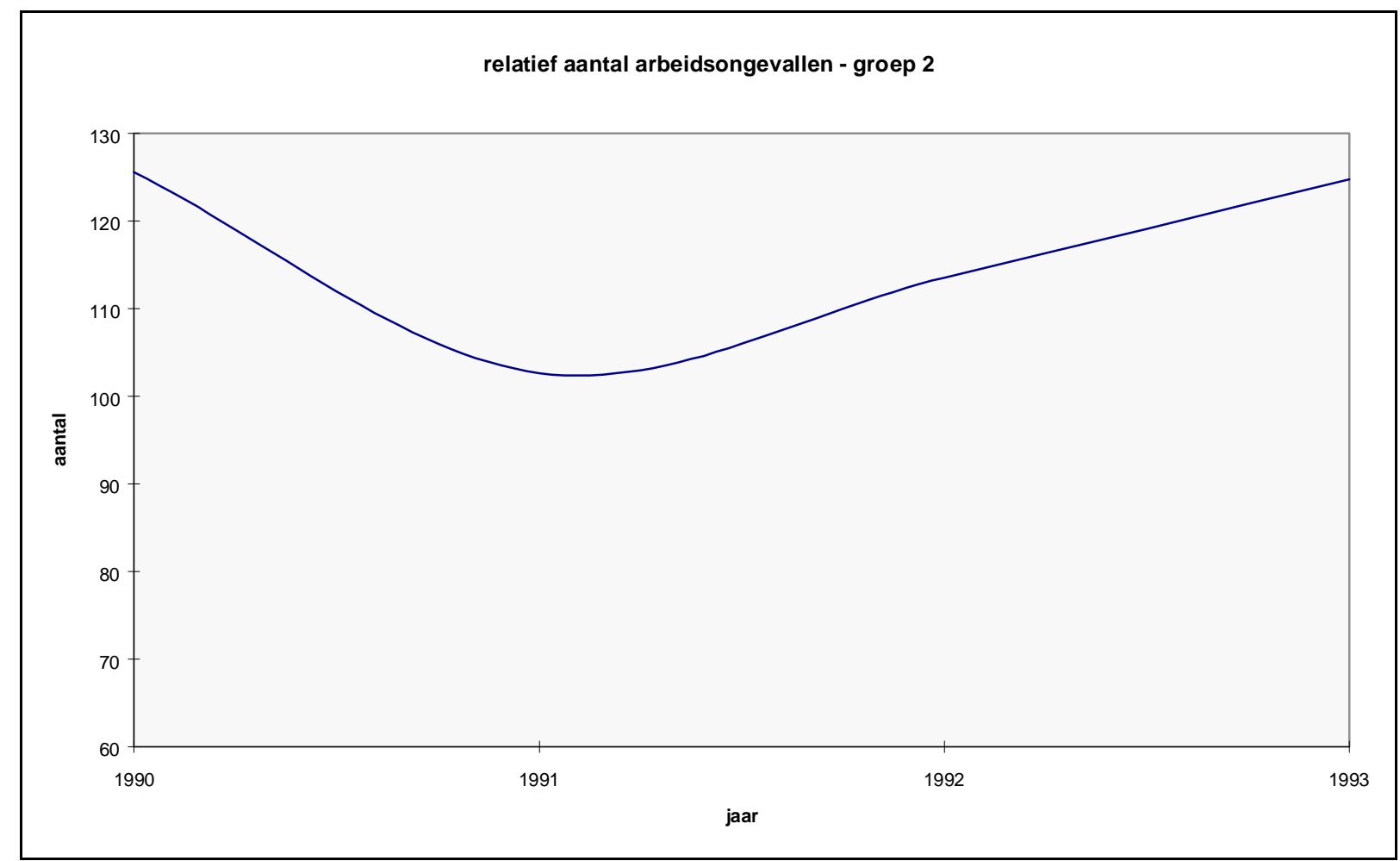

Grafiek 31: relatief aantal arbeidsongevallen - groep 3

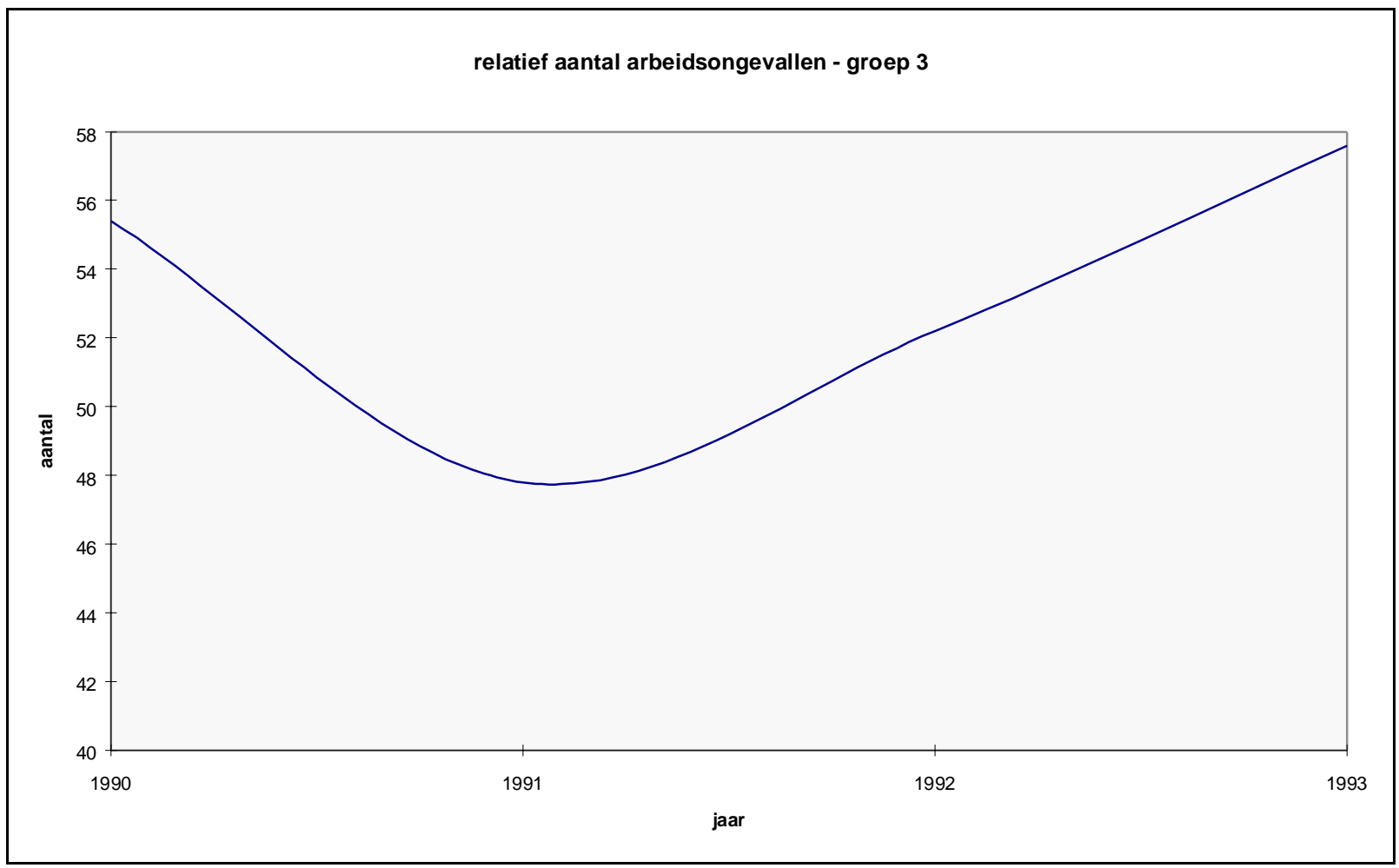




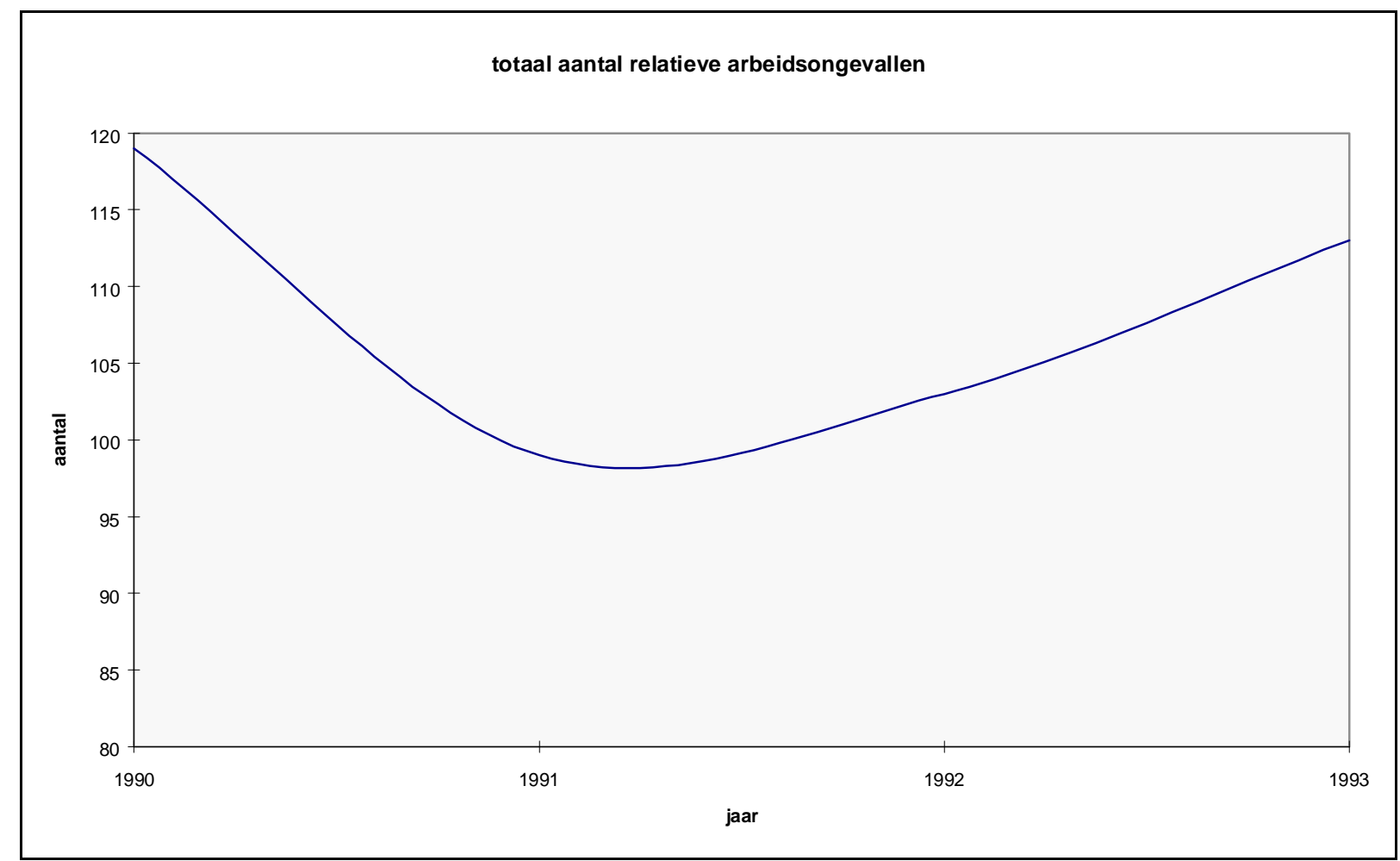

Grafiek 32: relatief aantal arbeidsongevallen - totaal 


\section{TRENDANALYSE RELATIEF AANTAL ARBEIDSONGEVALLEN}

Grafiek 33: schatting van relatief aantal arbeidsongevallen (per 100.000 werknemers) in de toekomst m.b.v. trendanalyse (1990 - 1993); alle groepen

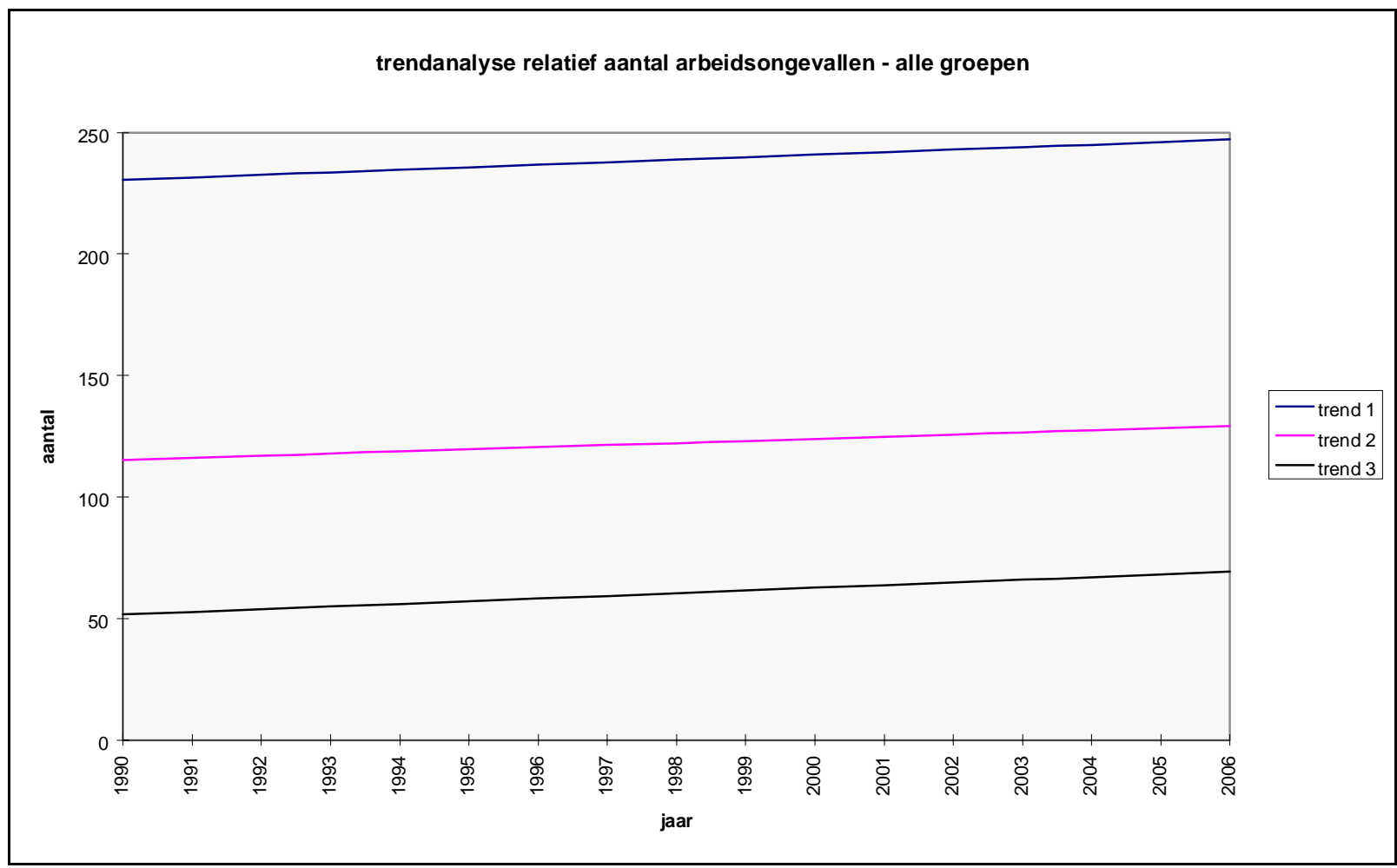

groep $1: \mathrm{Q}=-1839,16+1,04 *$ jaar

totaal : $\mathrm{Q}=2896,6-1,4 *$ jaar

groep 2: $\mathrm{Q}=-1601,08+0,863 *$ jaar

groep $3: \mathrm{Q}=-2137,4+1,1 *$ jaar

Grafiek 34: schatting van relatief aantal arbeidsongevallen (per 100.000 werknemers) m.b.v. trendanalyse (1990 - 1993); totaal 
Grafiek 35: schatting van relatief aantal arbeidsongevallen (per 100.000 werknemers) in de toekomst m.b.v. trendanalyse (1991 - 1993); alle groepen

groep $1: \mathrm{Q}=-39215,33+19,8 *$ jaar $\quad$ totaal $: \mathrm{Q}=-13829+7 *$ jaar

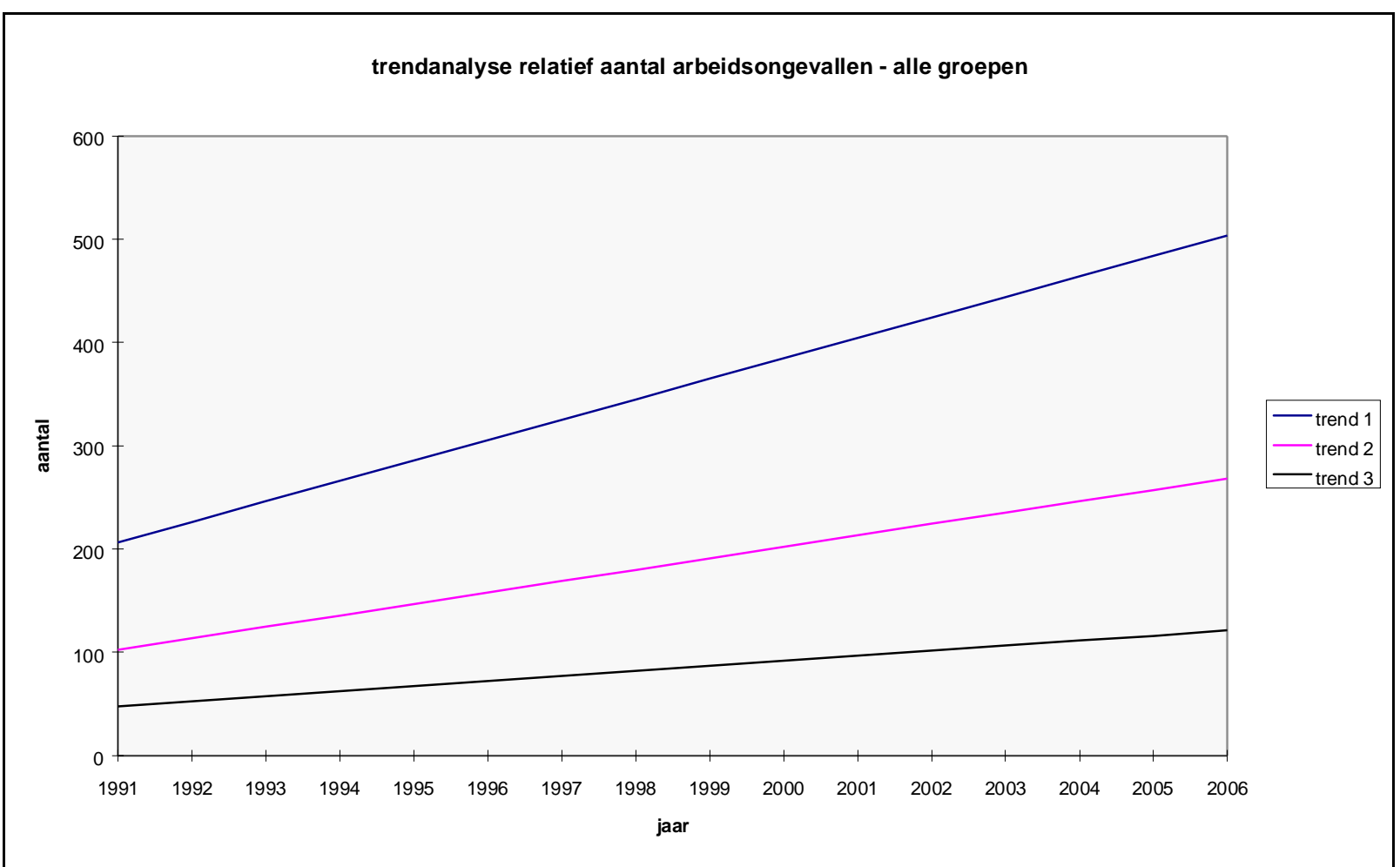

groep $2: Q=-21922,88+11,06 *$ jaar

groep $3: \mathrm{Q}=-9708,27+4,9 *$ jaar

trendanalyse aantal relatieve arbeidsongevallen; totaal

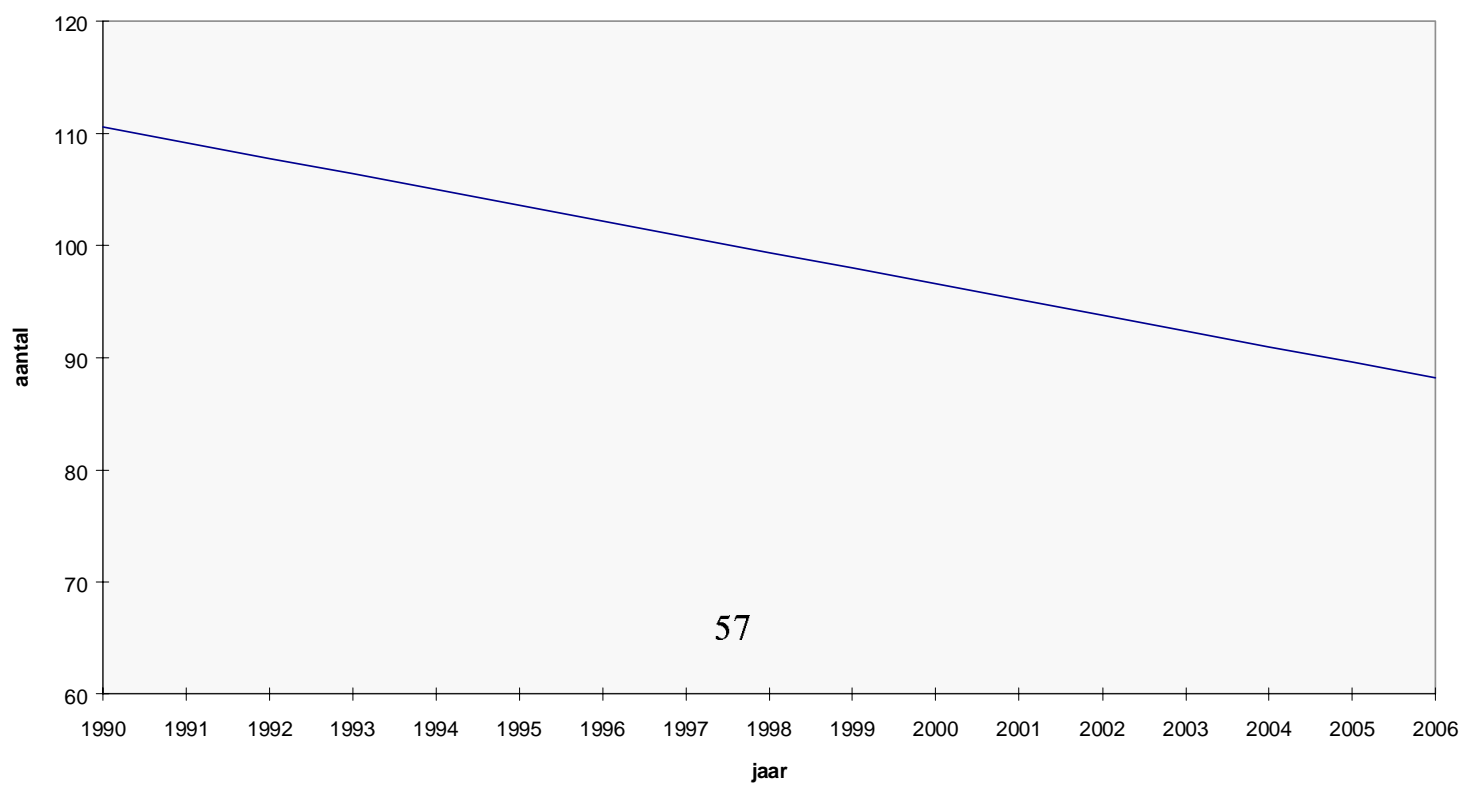


Grafiek 36: schatting van relatief aantal arbeidsongevallen (per 100.000 werknemers) in de toekomst m.b.v. trendanalyse (1991 - 1993)

Tabel 6: aantal arbeidsongevallen - absoluut en relatief - per groep; van 1990 tot en met 1993

\begin{tabular}{||l|l|l|l|l||}
\hline & $\mathbf{1 9 9 0}$ & $\mathbf{1 9 9 1}$ & $\mathbf{1 9 9 2}$ & $\mathbf{1 9 9 3}$ \\
\hline groep 1 - abs. & 647,40 & 542,80 & 578,40 & 629,80 \\
\hline groep 1 - rel. & 249,20 & 212,60 & 214,00 & 252,20 \\
\hline groep 2 - abs. & 159,75 & 143,00 & 148,75 & 166,63 \\
\hline groep 2 - rel. & 125,50 & 102,63 & 113,50 & 124,75 \\
\hline groep 3 - abs. & 44,80 & 33,80 & 36,00 & 41,80 \\
\hline groep 3 - rel. & 55,40 & 47,80 & 52,20 & 57,60 \\
\hline
\end{tabular}

trendanalyse relatief aantal arbeidsongevallen; totaal

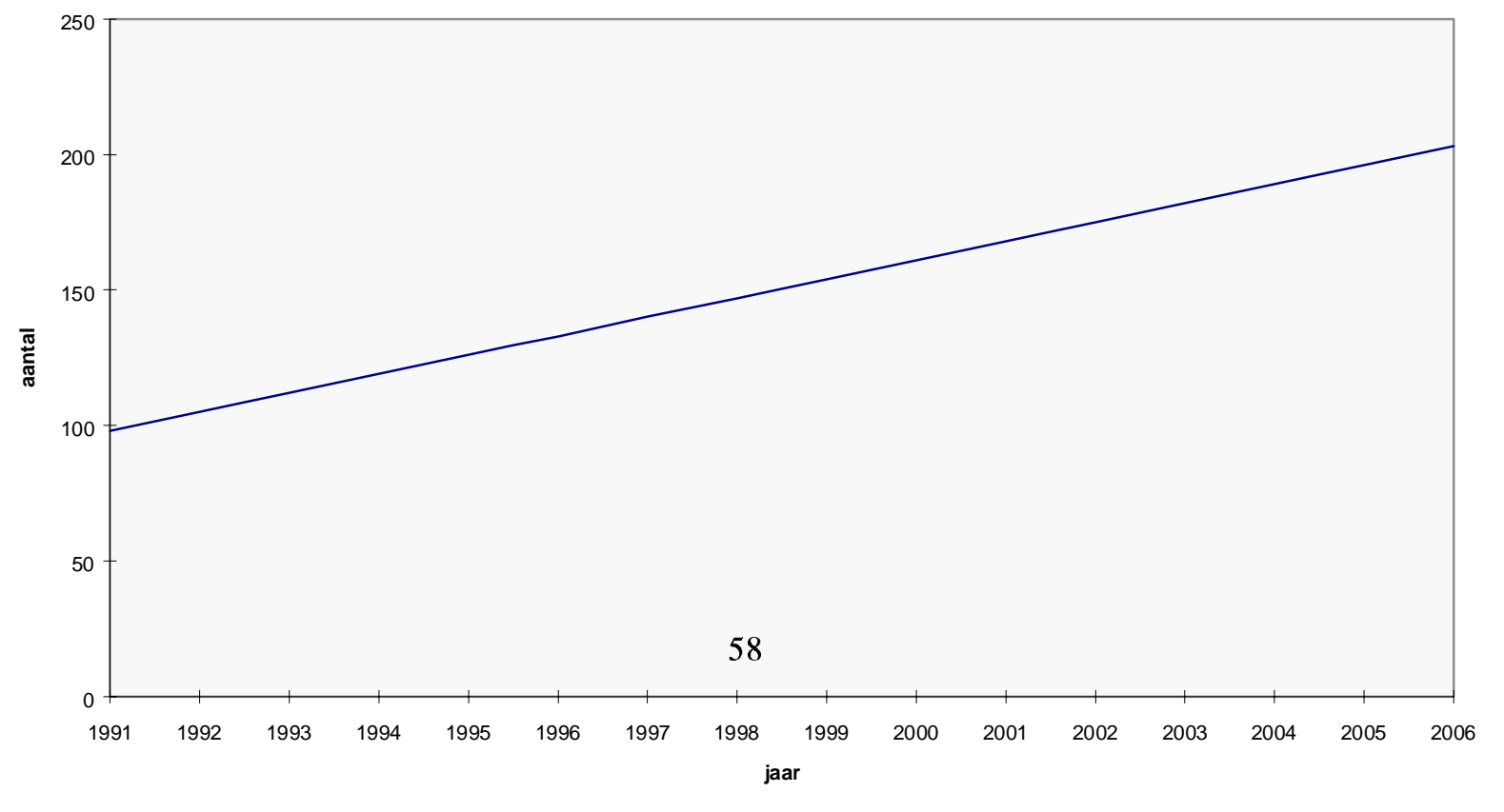




\section{deel 5}

kostenanalyse beroepsziekten 


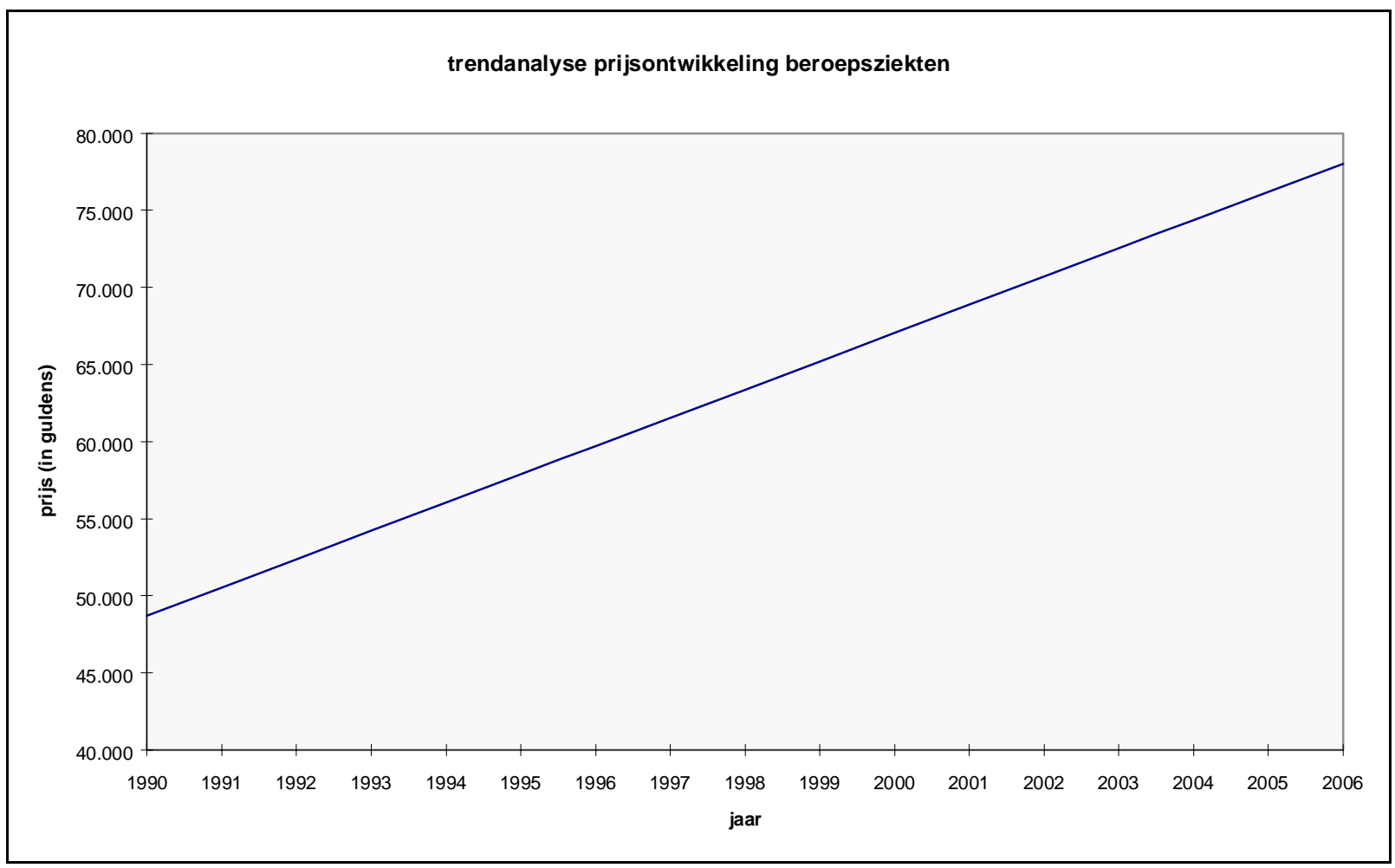

Grafiek 37: trendanalyse prijsontwikkeling beroepsziekten

$\mathrm{Q}=-3600446,982+1833,743 *$ jaar 
Grafiek 38: absolute kosten beroepsziekten - alle groepen

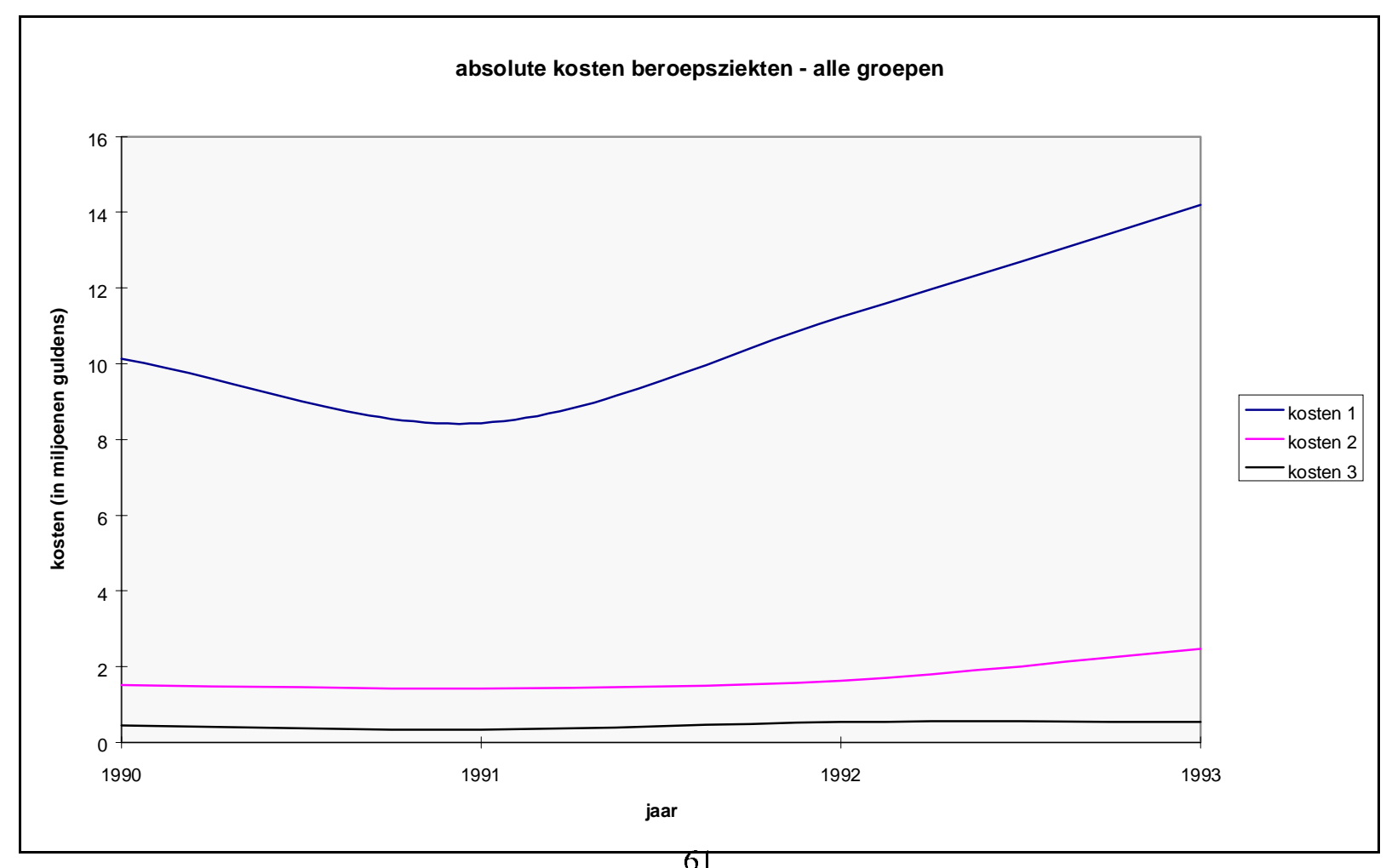


Grafiek 39: totale absolute kosten beroepsziekten

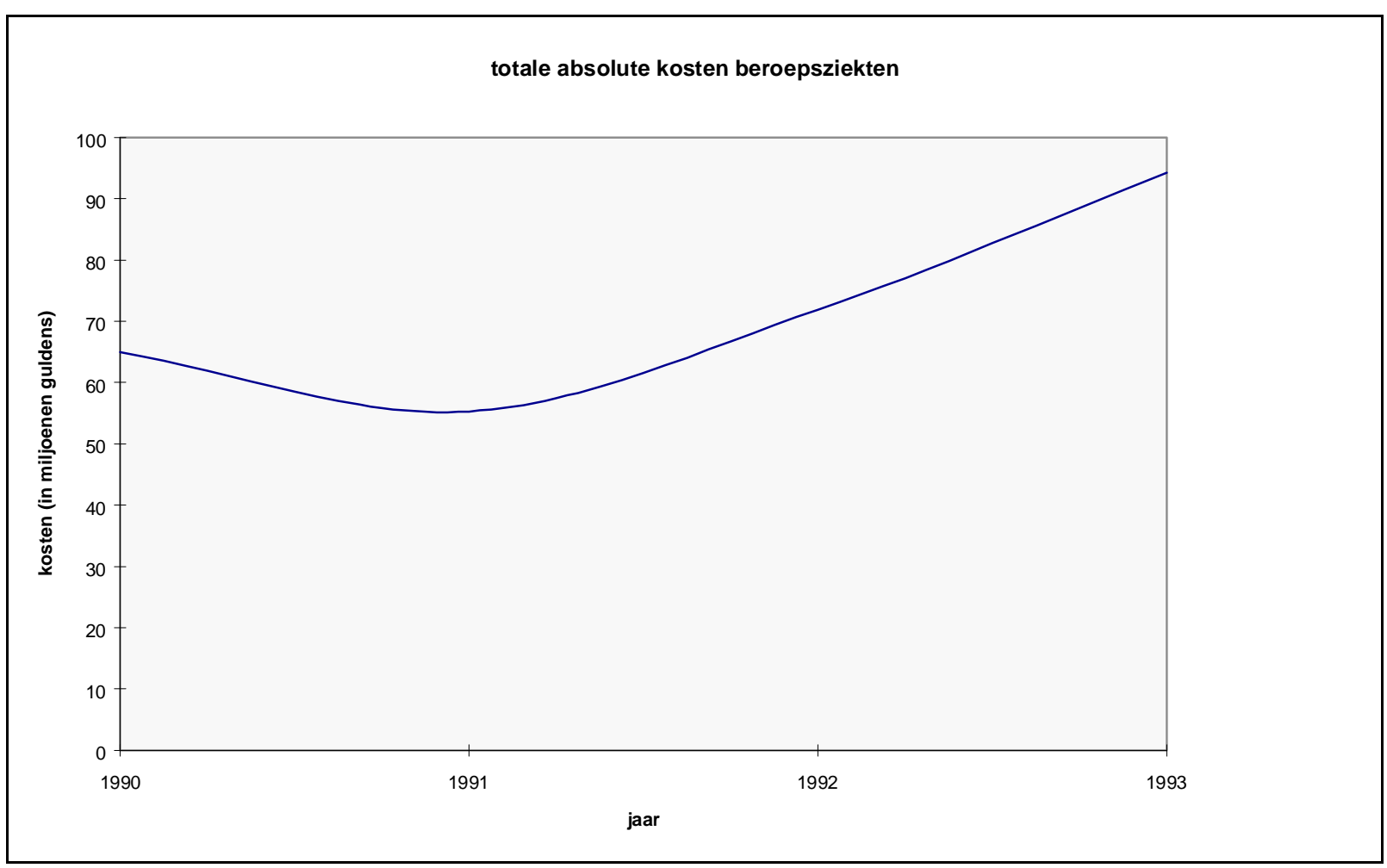

Grafiek 40: schatting absolute kosten beroepsziekten in de toekomst m.b.v. trendanalyse (1990 - 1993)

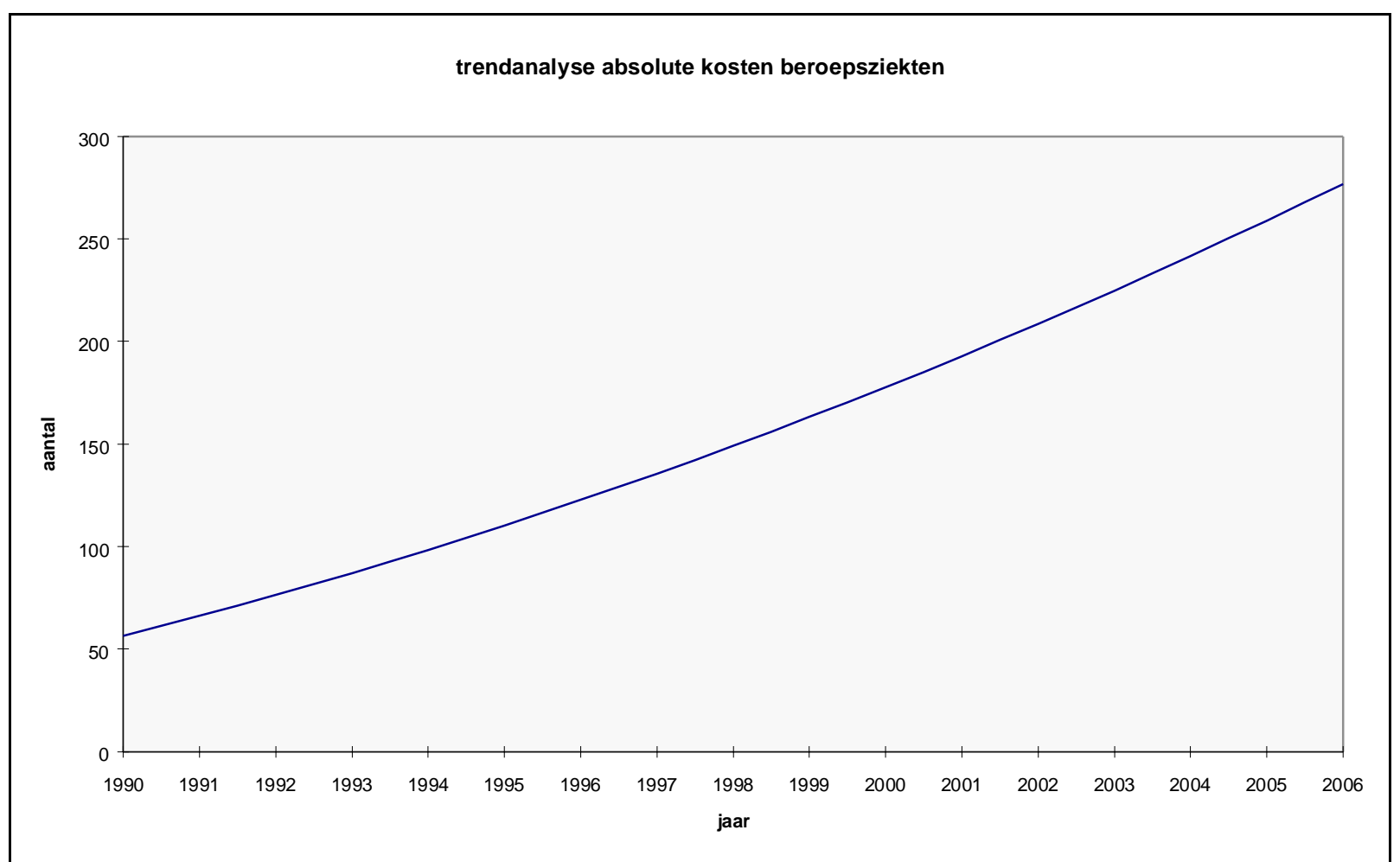


Grafiek 41: relatieve kosten beroepsziekten - alle groepen

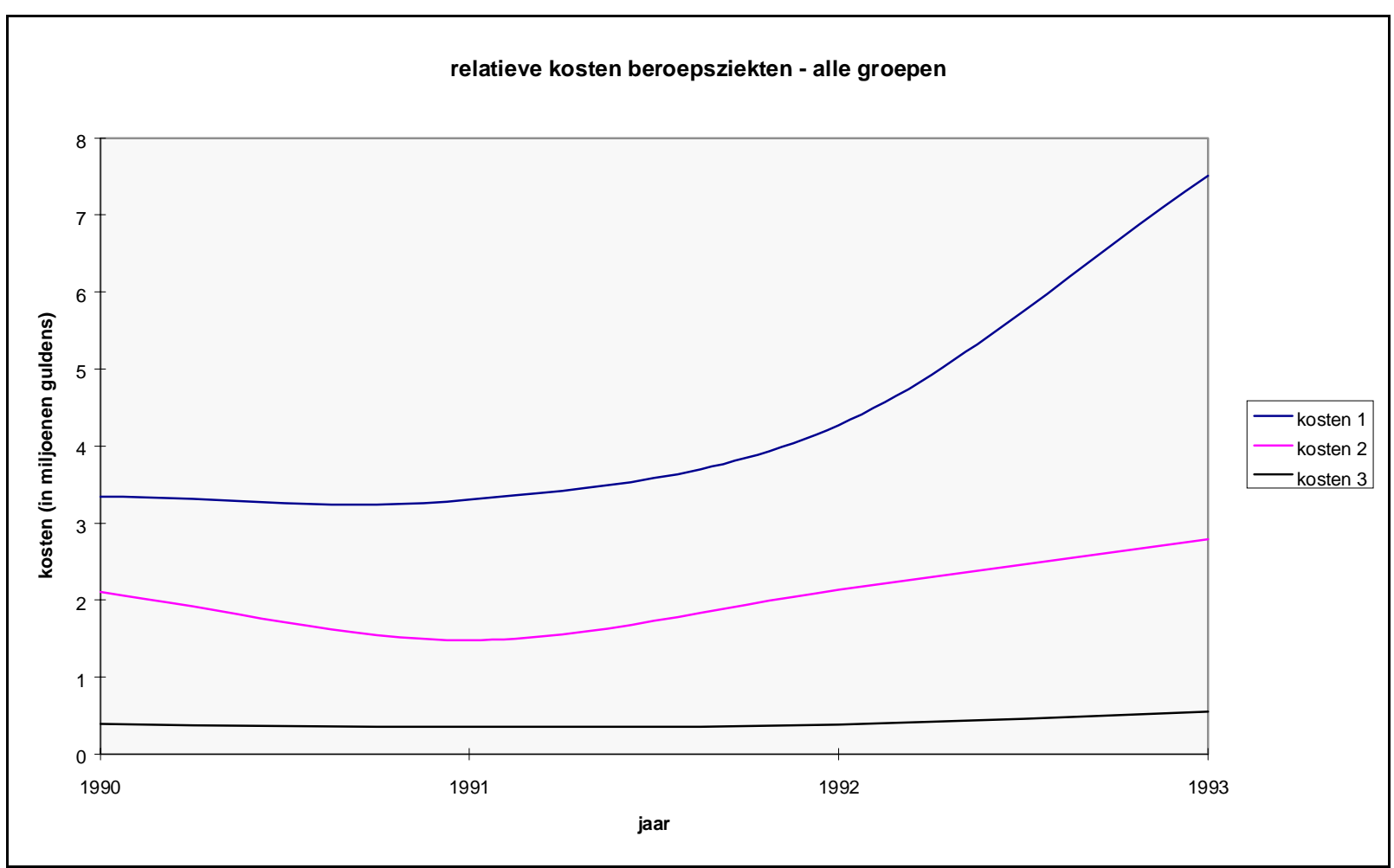

Grafiek 42: totale relatieve kosten beroepsziekten

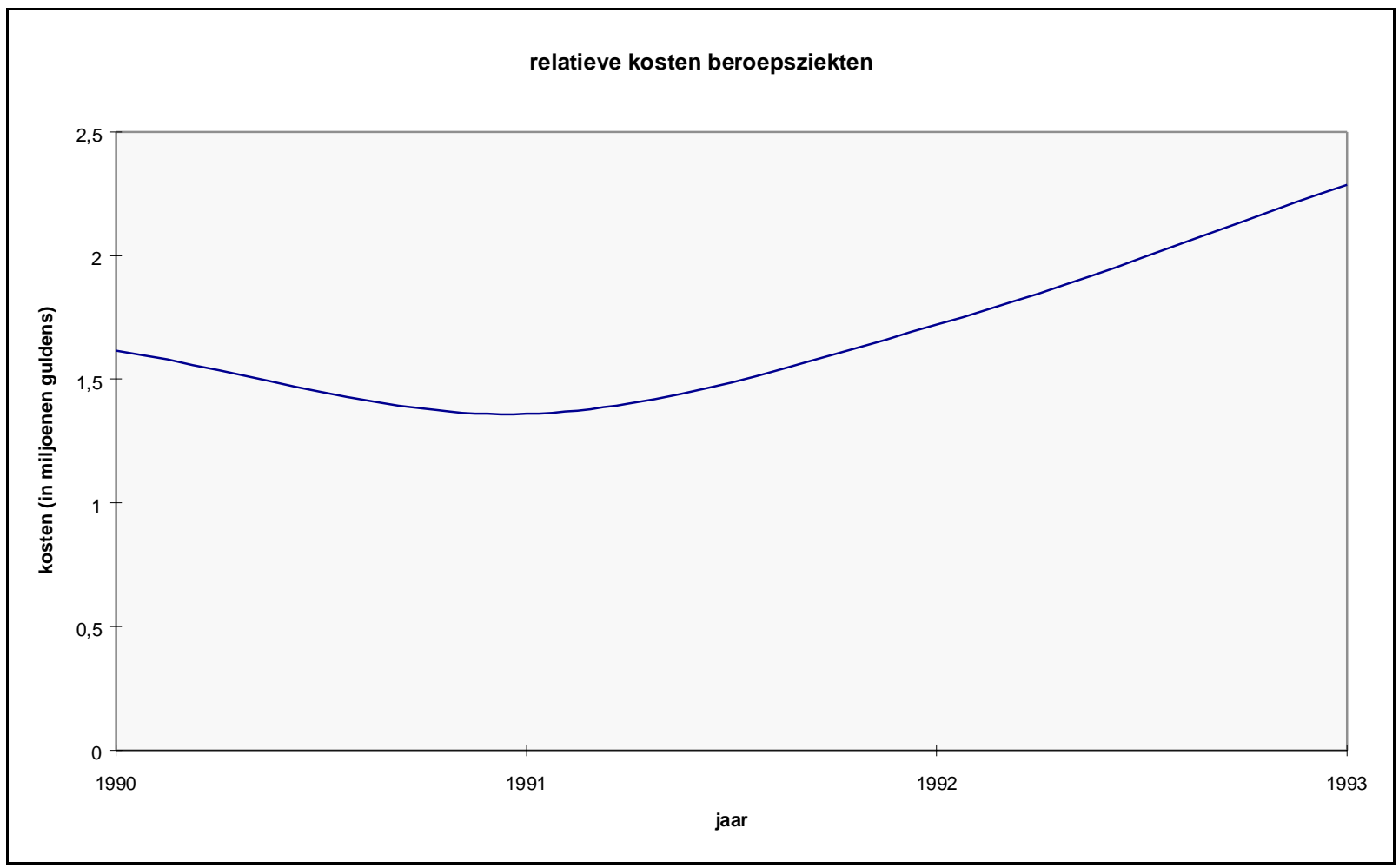




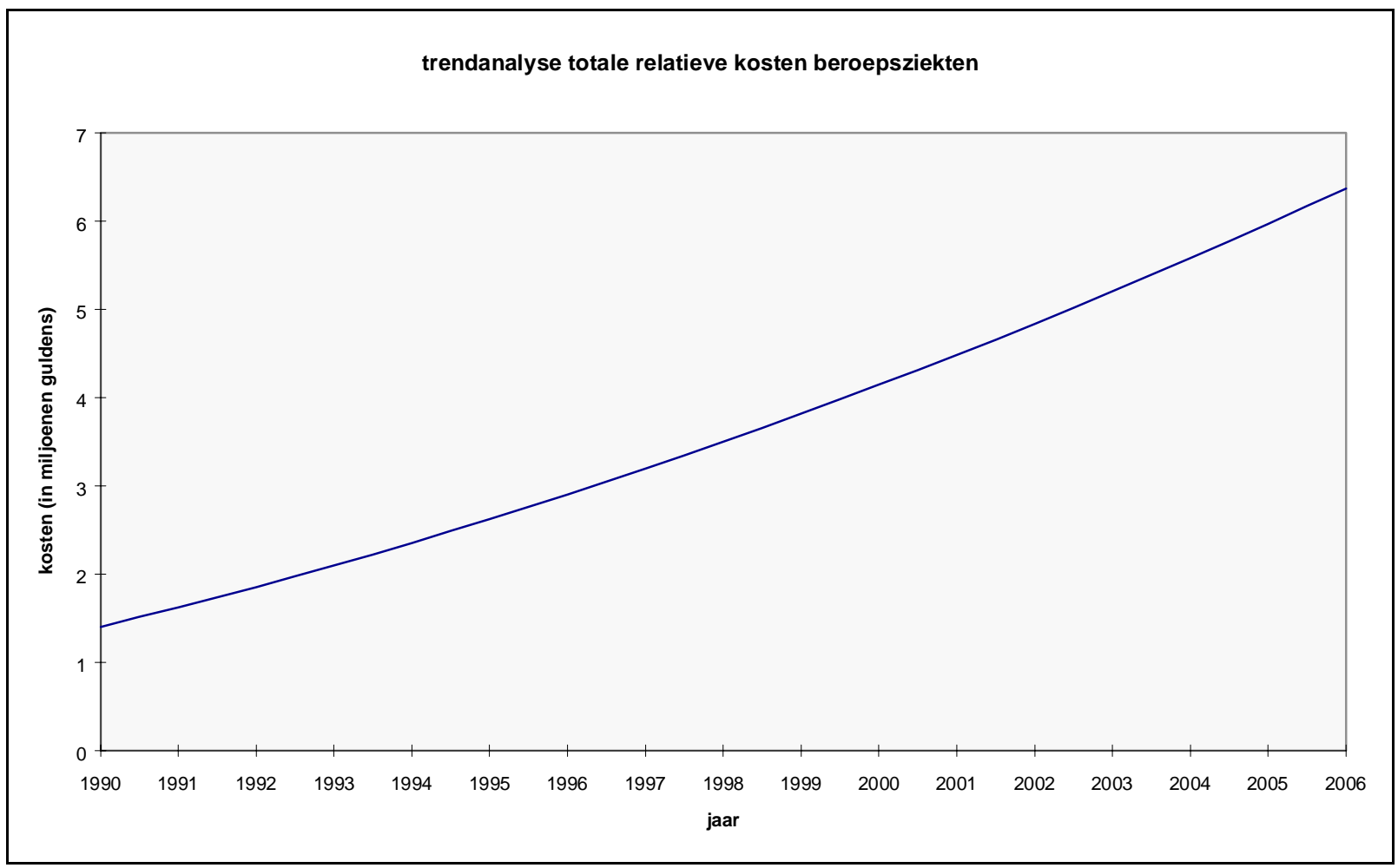

Grafiek 43: schatting totale relatieve kosten beroepsziekten in de toekomst m.b.v. trendanalyse (1990 - 1993) 